Prepared in cooperation with the San Antonio River Authority and the San Antonio Metropolitan Health District Public Center for Environmental Health

\title{
Assessment of Selected Contaminants in Streambed- and Suspended-Sediment Samples Collected in Bexar County, Texas, 2007-09
}

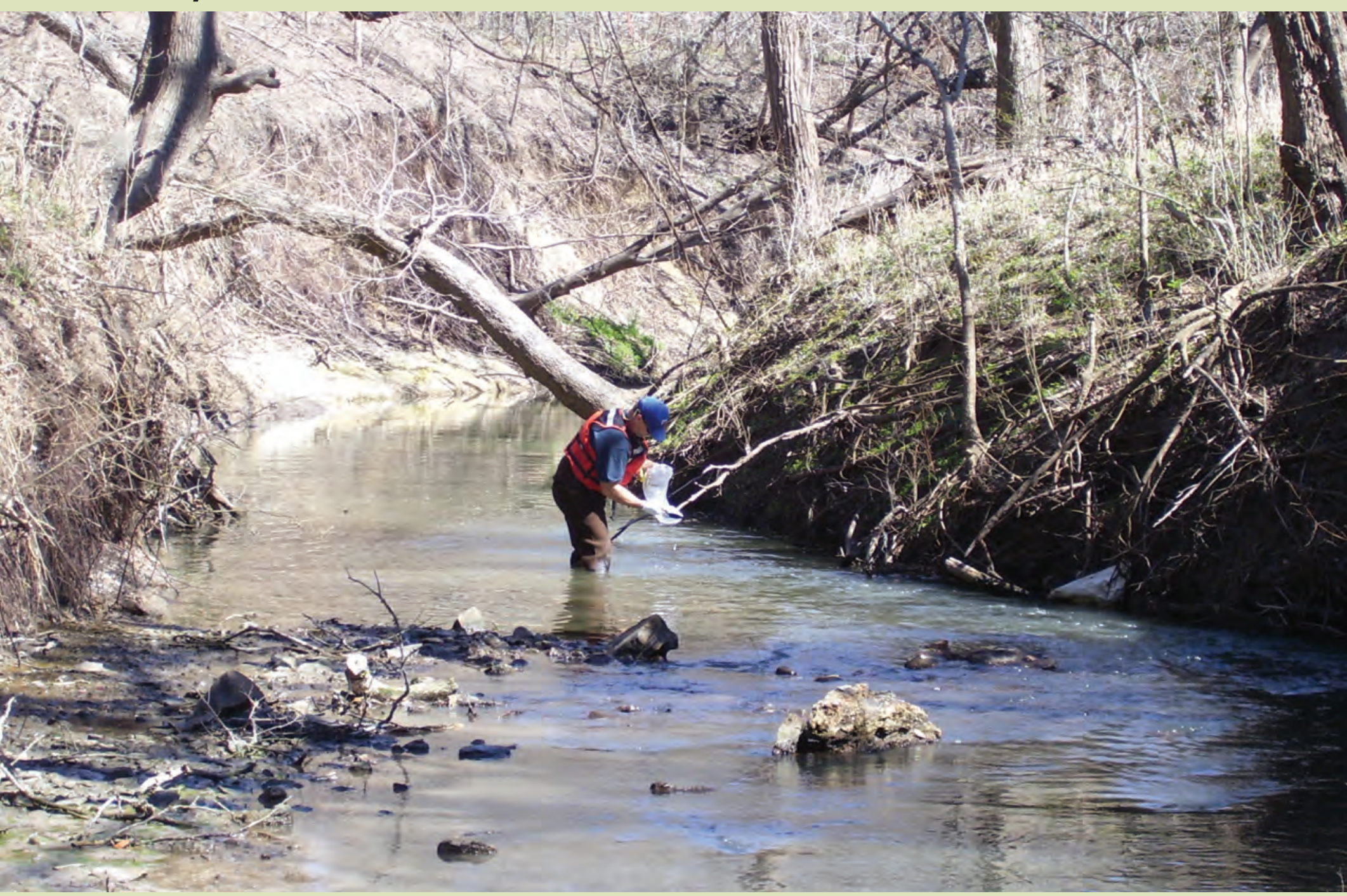

Scientific Investigations Report 2011-5097 
Front cover: U.S. Geological Survey hydrologic technician collecting streambed-sediment sample from Martinez Creek at Farm Road 1518 near St. Hedwig, Texas, February 2008.

Back cover: U.S. Geological Survey hydrologic technician collecting streambed-sediment sample from Rosillo Creek at New Sulphur Springs Road, San Antonio, Texas, August 2009. 


\section{Assessment of Selected Contaminants in Streambed- and Suspended-Sediment Samples Collected in Bexar County, Texas, 2007-09}

By Jennifer T. Wilson

Prepared in cooperation with the San Antonio River Authority and the San

Antonio Metropolitan Health District Public Center for Environmental Health

Scientific Investigations Report 2011-5097 


\title{
U.S. Department of the Interior \\ KEN SALAZAR, Secretary \\ U.S. Geological Survey \\ Marcia K. McNutt, Director
}

\section{U.S. Geological Survey, Reston, Virginia: 2011}

\author{
This and other USGS information products are available at http://store.usgs.gov/ \\ U.S. Geological Survey \\ Box 25286, Denver Federal Center \\ Denver, CO 80225 \\ To learn about the USGS and its information products visit http://www.usgs.gov/ \\ 1-888-ASK-USGS
}

\begin{abstract}
Any use of trade, product, or firm names is for descriptive purposes only and does not imply endorsement by the U.S. Government.

Although this report is in the public domain, permission must be secured from the individual copyright owners to reproduce any copyrighted materials contained within this report.
\end{abstract}

Suggested citation:

Wilson, J.T., 2011, Assessment of selected contaminants in streambed- and suspended-sediment samples collected in Bexar County, Texas, 2007-09: U.S. Geological Survey Scientific Investigations Report 2011-5097, 57 p.

(Appendixes available online at http://pubs.usgs.gov/sir/2011/5097/.) 


\section{Acknowledgments}

Lackland Air Force Base personnel assisted with base access. The Base Closure and Realignment Commission assisted with historical sample results. San Antonio Missions National Historical Park, National Park Service, provided access to the sampling site on the San Antonio River near Interstate Highway 410. Christopher Ellison, U.S. Geological Survey, provided assistance with statistical analyses. 



\section{Contents}

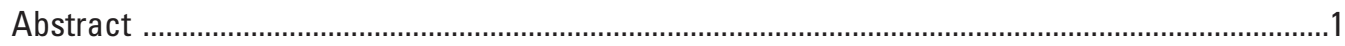

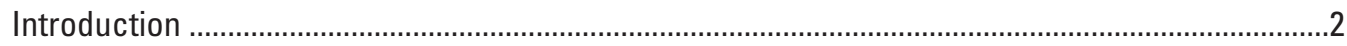

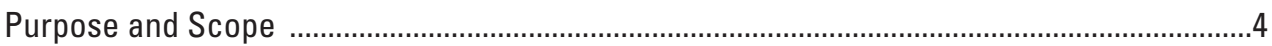

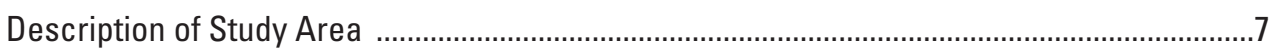

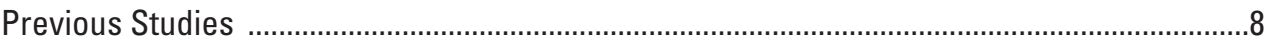

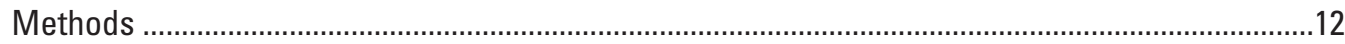

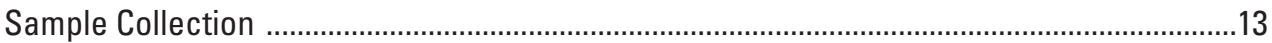

Streambed-Sediment Samples .....................................................................................14

Large-Volume Suspended-Sediment Samples .........................................................14

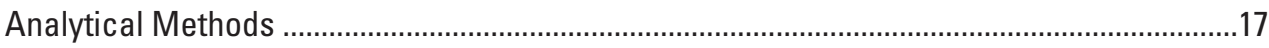

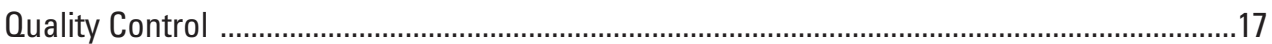

Assessment of Selected Contaminants in Streambed- and Suspended-Sediment Samples ........19

Occurrence and Distribution of Sediment-Associated Constituents .....................................20

Comparison of Findings to Sediment-Quality Guidelines ....................................................29

Comparison of Findings to Data from Previous Studies ........................................................33

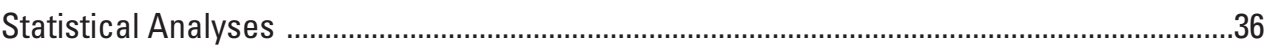

Similarity or Difference of Contaminant Concentration by Watershed ...........................37

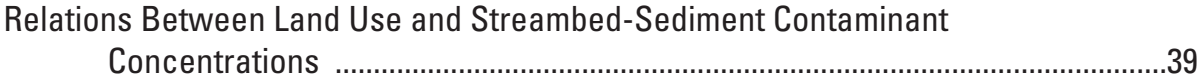

Indicators of Selected Organic Contaminant Sources .........................................................45

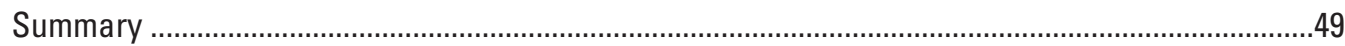

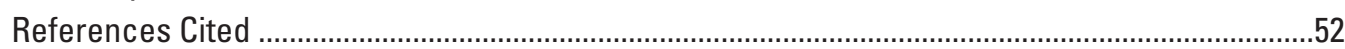

Appendixes (available online at http://pubs.usgs.gov/sir/2011/5097/)

1.1. Concentrations of major and trace elements in streambed-sediment and largevolume suspended-sediment (LVSS) samples collected from sites in Bexar County, Texas, 2007-09

1.2. Concentrations of halogenated organic compounds in streambed-sediment and large-volume suspended-sediment (LVSS) samples collected from sites in Bexar County, Texas, 2007-09

1.3. Concentrations of semivolatile organic compounds and polycyclic aromatic hydrocarbons in streambed-sediment and large-volume suspended-sediment (LVSS) samples collected from sites in Bexar County, Texas, 2007-09

1.4. Suspended-sediment concentration (SSC) and grain size in large-volume suspended-sediment (LVSS) samples collected from selected sites in Bexar County, Texas, 2008-09

2.1. Quality-control samples for major and trace element analyses of streambed-and suspended-sediment samples collected from selected sites in Bexar County, Texas, 2007-09

2.2. Quality-control samples for halogenated organic compound analyses of streambed- and suspended-sediment samples collected from selected sites in Bexar County, Texas, 2007-09.

2.3. Quality-control samples for semivolatile organic compound and polycyclic aromatic hydrocarbon analyses of streambed- and suspended-sediment samples collected from selected sites in Bexar County, Texas, 2007-09

3.1. Concentrations of trace elements and halogenated organic compounds in biological samples collected by the U.S. Geological Survey from sites in selected watersheds of Bexar County, Texas, 1995-97 
3.2. Concentrations of trace elements, organic carbon, halogenated organic compounds, and polycyclic aromatic hydrocarbons in streambed-sediment samples collected by the U.S. Geological Survey from sites in selected watersheds of Bexar County, Texas, 1995-2001

4.0. Concentrations of selected trace elements, halogenated organic compounds, and polycyclic aromatic hydrocarbons in streambed-sediment samples collected by the U.S. Air Force Center for Engineering and the Environment from sites on Leon Creek in Bexar County, Texas, 1994-2008

\section{Figures}

1-2. Maps showing:

1. Locations of streambed-sediment and suspended-sediment sampling sites in Bexar County, Texas, 2007-09

2. Land use in associated contributing area of each site where streambedsediment and suspended-sediment samples were collected in Bexar County, Texas, 2007-09

3. Graph showing top 10 potential sources of contamination in contributing areas of sites where streambed-sediment and suspended-sediment samples were collected in Bexar County, Texas, 2007-09

4. Map showing location of U.S. Air Force Center for Engineering and the Environment (AFCEE) and U.S. Geological Survey (USGS) streambed-sediment sampling sites on Leon Creek, Bexar County, Texas

5. Hyetograph showing rainfall at San Antonio International Airport and hydrographs showing stream discharge and streambed-sediment and suspended-sediment sampling at selected sites in Bexar County, Texas, 2007-09

6. Schematic (A) and photographs (B and $C$ ) of passive samplers used to collect large-volume suspended-sediment samples at selected sites in Bexar County, Texas, 2007-09

7-13. Graphs showing:

7. Detection frequencies of halogenated organic compounds in streambedsediment and suspended-sediment samples, by watershed, in Bexar County, Texas, 2007-09

8. Concentrations of the four most frequently detected brominated flame retardants in streambed-sediment and suspended-sediment samples collected from sites in Bexar County, Texas, 2007-09

9. Comparison of concentrations of selected contaminants in streambedsediment samples to concentrations in suspended-sediment samples collected from selected sites in Bexar County, Texas, 2007-09

10. Comparison of consensus-based sediment-quality guidelines with concentrations of selected trace elements in streambed-sediment and suspended-sediment samples collected from sites in Bexar County, Texas, 2007-09

11. Comparison of consensus-based sediment-quality guidelines with concentrations of selected halogenated organic compounds in streambedsediment and suspended-sediment samples collected from sites in Bexar County, Texas, 2007-09

12. Graphs showing comparison of consensus-based sediment-quality guidelines with concentrations of selected polycyclic aromatic hydrocarbons (PAHs) and total PAHs in streambed-sediment and suspended-sediment samples collected from sites in Bexar County, Texas, 2007-09 
13. Mean probable effect concentration quotient of streambed-sediment and suspended-sediment samples collected from sites in Bexar County, Texas, 2007-09

14. Map showing locations of U.S. Environmental Protection Agency (USEPA)

Superfund sites and Toxics Release Inventory (TRI) Program facilities and industries in contributing areas of streambed-sediment sampling sites in Bexar County, Texas, 2007-09

15-16. Graphs showing:

15. Concentrations of detected polychlorinated biphenyl (PCB) congeners normalized to concentrations of total PCBs in streambed-sediment samples collected from selected sites in Bexar County, Texas, 2007-09

16. Comparison of polycyclic aromatic hydrocarbon (PAH) profiles for various PAH sources summarized in Van Metre and Mahler to PAH profile for average Bexar County sediment computed from samples from selected sites in Bexar County, Texas, 2007-09

\section{Tables}

1. Constituents analyzed in streambed-sediment and suspended-sediment samples collected in Bexar County, Texas, 2007-09, and constituent rank on 2007 "Comprehensive Environmental Response, Compensation, and Liability Act Priority List of Hazardous Substances"

2. Characteristics of associated contributing area of each site where streambedsediment and suspended-sediment samples were collected in Bexar County, Texas, 2007-09

3. Streambed-sediment and suspended-sediment samples collected in contributing areas of sites in Bexar County, Texas, 2007-09

4. Suspended-sediment concentration and mass of contaminant per unit volume of stormwater for large-volume suspended-sediment samples collected by passive samplers at selected sites in Bexar County, Texas, 2008-09

5. Consensus-based sediment-quality guidelines used for comparison to contaminant concentrations in streambed-sediment and suspended-sediment samples collected from sites in Bexar County, Texas, 2007-09

6. Percent detections, ranges, means, and standard deviations of sedimentassociated constituents in sediment samples collected by the U.S. Air Force Center for Engineering and the Environment (AFCEE) during 1994-2008 and by the U.S. Geological Survey (USGS) during 2007-09 from Leon Creek in Bexar County, Texas

7. Percent detections, ranges, means, and standard deviations of selected constituents in suspended-sediment samples collected from streams in the Austin, Texas, area during 1999-2004, from streams in the Fort Worth, Texas, area during 2000-2002, and from streams in Bexar County, Texas, during 2007-09

8. Results of Kruskal-Wallis nonparametric tests for differences among trace element, halogenated organic compound, and polycyclic aromatic hydrocarbon concentrations in streambed-sediment samples from sample-collection sites in Bexar County, Texas, 2007-09

9. Military installations, U.S. Environmental Protection Agency Superfund sites, and U.S. Environmental Protection Agency Toxics Release Inventory Program facilities and industries in the contributing areas of the streambed-sediment sampling sites in Bexar County, Texas, 2007-09 
10. Results of Mann-Whitney $\mathrm{U}$ test used to assess differences in contaminant concentrations measured in streambed-sediment samples on the basis of the presence or absence of suspected contaminant sources in selected watersheds of Bexar County, Texas, 2007-09

11. Kendall's tau nonparametric correlation coefficients between population density, land use, or potential sources of contamination (PSOCs) and median streambedsediment contaminant concentrations in all 20 contributing areas of the sampling sites in Bexar County, Texas, 2007-09

12. Chemical mass balance model results and average fractional loading of total polycyclic aromatic hydrocarbons by source category for sampling sites in Bexar County, Texas, 2007-09

\section{Conversion Factors, Datum, Water-Quality Units, and Selected Abbreviations}

\section{Inch/Pound to SI}

\begin{tabular}{lll}
\hline \multicolumn{1}{c}{ Multiply } & By & \multicolumn{1}{c}{ To obtain } \\
\hline centimeter $(\mathrm{cm})$ & Length & \\
millimeter $(\mathrm{mm})$ & 0.3937 & inch (in.) \\
meter $(\mathrm{m})$ & 0.03937 & inch (in.) \\
kilometer $(\mathrm{km})$ & 3.281 & foot (ft) \\
\hline & 0.6214 & mile (mi) \\
\hline square kilometer $\left(\mathrm{km}^{2}\right)$ & Area & \\
\hline & 0.3861 & square mile (mi²) \\
\hline liter $(\mathrm{L})$ & Volume & \\
milliliter $(\mathrm{mL})$ & 0.2642 & gallon (gal) \\
& 0.03382 & ounce, fluid (fl. oz) \\
\hline gram $(\mathrm{g})$ & Mass & \\
\hline & 0.03527 & ounce, avoirdupois (oz) \\
\hline kilopascal $(\mathrm{kPa})$ & Pressure & \\
kilopascal $(\mathrm{kPa})$ & 0.009869 & atmosphere, standard (atm) \\
\hline
\end{tabular}

Temperature in degrees Celsius $\left({ }^{\circ} \mathrm{C}\right)$ may be converted to degrees Fahrenheit $\left({ }^{\circ} \mathrm{F}\right)$ as follows:

$$
{ }^{\circ} \mathrm{F}=\left(1.8 \times^{\circ} \mathrm{C}\right)+32
$$

\section{Datum}

Horizontal coordinate information is referenced to North American Datum of 1983 (NAD 83). 


\section{Water-Quality Units}

$\mathrm{g} / \mathrm{kg}$, grams per kilogram

$\mu \mathrm{g} / \mathrm{g}$, micrograms per gram

$\mu \mathrm{g} / \mathrm{kg}$, micrograms per kilogram

$\mu \mathrm{g} / \mathrm{L}$, micrograms per liter

$\mu \mathrm{m}$, micrometers

$\mathrm{mg} / \mathrm{L}$, milligrams per liter

$\mathrm{ng} / \mathrm{L}$, nanograms per liter

\section{Selected Abbreviations}

ATSDR Agency for Toxic Substances and Disease Registry

AFB Air Force Base

AFCEE Air Force Center for Engineering and the Environment

CMB Chemical mass balance

CERCLA Comprehensive Environmental Response, Compensation, and Liability Act

DSHS Department of State Health Services

DDD Common name for dichlorodiphenyldichloroethane

DDE Common name for dichlorodiphenyldichloroethylene

DDT Common name for dichlorodiphenyltrichloroethane

HAC Health-based assessment comparison

IRL Interim reporting level

LVSS Large-volume suspended-sediment

LRL Laboratory reporting level

NAWQA National Water-Quality Assessment

NWQL National Water Quality Laboratory

PCB Polychlorinated biphenyl

PAH Polycyclic aromatic hydrocarbon

PBDE Polybrominated diphenyl ether

PSOC Potential sources of contamination

PEC Probable effect concentration

RCRA Resource Conservation and Recovery Act

SQG Sediment quality guideline

SVOC Semivolatile organic compound

SSC Suspended sediment concentration

TCEQ Texas Commission on Environmental Quality

TEC Threshold effect concentration

USEPA U.S. Environmental Protection Agency 



\title{
Assessment of Selected Contaminants in Streambed- and Suspended-Sediment Samples Collected in Bexar County, Texas, 2007-09
}

\author{
By Jennifer T. Wilson
}

\begin{abstract}
Elevated concentrations of sediment-associated contaminants are typically associated with urban areas such as San Antonio, Texas, in Bexar County, the seventh most populous city in the United States. This report describes an assessment of selected sediment-associated contaminants in samples collected in Bexar County from sites on the following streams: Medio Creek, Medina River, Elm Creek, Martinez Creek, Chupaderas Creek, Leon Creek, Salado Creek, and San Antonio River. During 2007-09, the U.S. Geological Survey periodically collected surficial streambed-sediment samples during base flow and suspended-sediment (large-volume suspended-sediment) samples from selected streams during stormwater runoff. All sediment samples were analyzed for major and trace elements and for organic compounds including halogenated organic compounds and polycyclic aromatic hydrocarbons (PAHs). Selected contaminants in streambed and suspended sediments in watersheds of the eight major streams in Bexar County were assessed by using a variety of methods-observations of occurrence and distribution, comparison to sediment-quality guidelines and data from previous studies, statistical analyses, and source indicators.

Trace elements concentrations were low compared to the consensus-based sediment-quality guidelines threshold effect concentration (TEC) and probable effect concentration (PEC). Trace element concentrations were greater than the TEC in 28 percent of the samples and greater than the PEC in 1.5 percent of the samples. Chromium concentrations exceeded sediment-quality guidelines more frequently than concentrations of any other constituents analyzed in this study (greater than the TEC in 69 percent of samples and greater than the PEC in 8 percent of samples). Mean trace element concentrations generally are lower in Bexar County samples compared to concentrations in samples collected during previous studies in the Austin and Fort Worth, Texas, areas, but considering the relatively large ranges and standard deviations associated with the concentrations measured in all three areas, the trace element concentrations are similar. On the basis of MannWhitney $\mathrm{U}$ test results, the presence of a military installation in a watershed was associated with statistically significant
\end{abstract}

higher chromium, mercury, and zinc concentrations in streambed sediments compared to concentrations of the same elements in a watershed without a military installation.

Halogenated organic compounds analyzed in sediment samples included pesticides (chlordane, dieldrin, DDT, DDD, and DDE), polychlorinated biphenyls (PCBs), and brominated flame retardants. Three or more halogenated organic compounds were detected in each sediment sample, and 66 percent of all concentrations were less than the respective interim reporting levels. Halogenated organic compound concentrations were mostly low compared to consensus-based sediment quality guidelines-TECs were exceeded in 11 percent of the analyses and PECs were exceeded in 1 percent of the analyses. Chlordane compounds were the most frequently detected halogenated organic compounds with one or more detections of chlordane compounds in every watershed; concentrations were greater than the TEC in 6 percent of the samples. Dieldrin was detected in 50 percent of all samples, however all concentrations were much less than the TEC. The DDT compounds ( $p, p^{\prime}$-DDT, $p, p^{\prime}$-DDD, and $p, p^{\prime}$-DDE) were detected less frequently than some other halogenated organic compounds, however most detections exceeded the TECs. $p, p^{\prime}$-DDT was detected in 13 percent of the samples (TEC exceeded in 67 percent); $p, p^{\prime}$-DDD was detected in 19 percent of the samples (TEC exceeded in 78 percent); and $p, p^{\prime}$-DDE was detected in 35 percent of the samples (TEC exceeded in 53 percent). $p, p^{\prime}$-DDE concentrations in streambed-sediment samples correlate positively with population density and residential, commercial, and transportation land use. One or more PCB congeners were detected in 90 percent of the samples. Additionally, total PCB concentrations in streambed-sediment samples correlated positively with residential, industrial, and mining land uses. The PCB mixtures in the samples from Leon Creek, Salado Creek, and the San Antonio River were dominated by PCB congeners 138, 180, and 187. The similar PCB congener patterns suggest similar PCB sources in the three watersheds. The results of the Mann-Whitney U test indicate that the presence of a military installation in a watershed was associated with statistically significant higher total chlordane, $p, p^{\prime}$-DDE, and total PCB concentrations. Brominated flame retardant compounds were detected most frequently in 
samples from the Medio Creek, Leon Creek, and San Antonio River watersheds. No sediment-quality guidelines exist for brominated flame retardant compounds. Mean halogenated organic compound concentrations generally are lower in Bexar County samples compared to concentrations in samples collected during previous studies in the Austin and Fort Worth areas.

The PAHs were detected most frequently in samples from the Leon Creek and San Antonio River watersheds. Total PAH concentrations exceeded the TEC in 14 percent of the samples and none of the concentrations exceeded the PEC. Total PAH concentrations in streambed-sediment samples correlate positively with population density; residential, commercial, transportation, and mining land-use categories; and industrial wastewater outfall, wastewater liftstation, and petroleum storage tank potential source of contamination categories. Mean total PAH concentrations generally are lower in Bexar County samples compared to concentrations in samples collected during previous studies in the Austin and Fort Worth areas, but considering the large ranges and standard deviations associated with the concentrations measured in all three areas, total PAH concentrations are similar. PAH sources were investigated by comparing the ratios of individual PAH compounds to total PAH of several common PAH sources, such as coal combustion (power plants), automobile-related sources, and coal-tar parking lot sealcoat, and the Bexar County streambedand suspended-sediment samples. The contribution from each PAH source was estimated by using a chemical mass balance model, which indicated that parking lot coal-tar sealcoat dust is the largest PAH source to the average Bexar County sediment, accounting for 70.2 to 78.9 percent of the PAHs in the mixture.

The overall degree of sediment contamination of the Bexar County sediment samples was assessed by using the mean PEC quotient. The incidence of sediment toxicity is highly correlated to the mean PEC quotient. Samples from Leon Creek at Lackland Air Force Base, Leon Creek at Quintana Road, Leon Creek at Interstate Highway 35, Leon Creek at Southwest Military Drive (Loop 13), and San Antonio River at Loop 410 (in order of decreasing values) had the highest mean PEC quotients.

\section{Introduction}

Elevated concentrations of sediment-associated contaminants are often measured in urban areas (for example, Rice, 1999; Wong and others, 2000; Chalmers and others, 2007). San Antonio, Tex. (fig. 1) currently (2010) is the seventh most populous city in the United States (U.S. Census Bureau, 2009), and as in other large cities, sediment-associated contaminants have been detected in the greater metropolitan area and documented in previous studies. For example, bottomsediment core samples collected in August 1996 from Lorence Creek Lake in the Salado Creek watershed in Bexar County showed upward trends in zinc, chlordane, and polycyclic aromatic hydrocarbon (PAH) concentrations over time (Ging and others, 1999). Legacy pollutants-lead, DDT (common name for dichlorodiphenyltrichloroethane), and polychlorinated biphenyls (PCBs) —also were detected in the bottom-sediment samples collected from Lorence Creek Lake. Many sediment-associated contaminants pose a threat to aquatic organisms and human health because they are persistent, bioaccumulative, and (or) toxic (U.S. Environmental Protection Agency, 1997). The Comprehensive Environmental Response, Compensation, and Liability Act (CERCLA) requires the Agency for Toxic Substances and Disease Registry (ATSDR) and U.S. Environmental Protection Agency (USEPA) to prepare a list, in order of priority, of substances that are found most commonly at facilities on the National Priorities List and that are determined to pose the most substantial potential threat to human health because of their known or suspected toxicity and potential for human exposure at these National Priorities List sites (Agency for Toxic Substances and Disease Registry, 2007a). The 2007 "CERCLA Priority List of Hazardous Substances" identified 275 substances, including 43 constituents that were analyzed in samples collected in Bexar County during 2007-09 (table 1).

Most trace elements and many human-made organic contaminants bind to sediments, and sediments accumulate on the streambed during low flows (Williamson and others, 1998). Constituents that bind preferentially to sediments and do not remain in the water column in appreciable amounts are classified as hydrophobic (Stumm and Morgan, 1981). Many researchers recognize that water-quality investigations of hydrophobic constituents are incomplete if studies of sediment chemistry are not included. Bradford and Horowitz (1988, p. 1) note, "the strong association of numerous toxic chemicals-both organic (such as PCBs, DDT, mirex, and kepone) and inorganic (such as arsenic, mercury, cadmium, and lead) with sediment means that much of the downstream transport of these materials cannot be detected or evaluated solely through the sampling and analysis of water." Furthermore, nonpointsource contributions of many of these contaminants might be intermittent or storm-related, thus single or periodic water sampling might not detect the contaminants (Shelton and Capel, 1994). Streambed-sediment samples from depositional environments provide a time-integrated sample of particulate matter transported by a stream. Suspended-sediment samples are useful for determining the concentration of hydrophobic contaminants in suspended sediments, which are ultimately deposited as bed sediment in a receiving water body, are in direct contact with aquatic biota of all trophic levels, and are more uniform in size and composition than streambed sediments and therefore have less spatial and temporal variability (Mahler and Van Metre, 2003). Passive samplers provide a cost effective means for collecting large-volume suspendedsediment samples that can be used to determine if a particular constituent is present in a stream during the rising limb of the hydrograph as a result of stormwater runoff (Van Metre and others, 2003). 


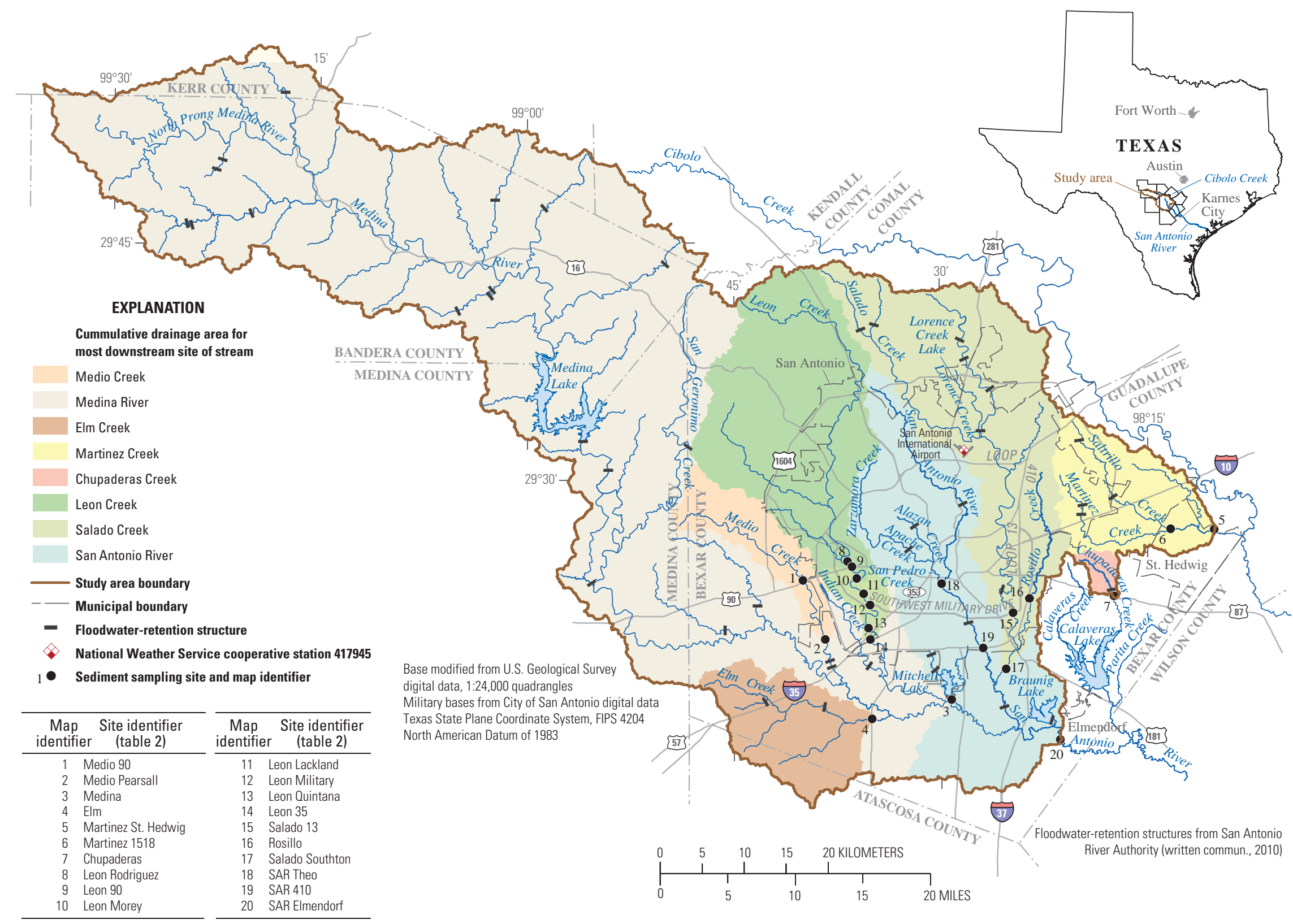

Figure 1. Locations of streambed-sediment and suspended-sediment sampling sites in Bexar County, Texas, $2007-09$. 
Table 1. Constituents analyzed in streambed-sediment and suspended-sediment samples collected in Bexar County, Texas, 2007-09, and constituent rank on 2007 "Comprehensive Environmental Response, Compensation, and Liability Act Priority List of Hazardous Substances" (Agency for Toxic Substances and Disease Registry, 2007a).

\begin{tabular}{llll}
\hline & \multicolumn{3}{c}{ Trace elements } \\
\hline 1. Arsenic & 49. Cobalt & 101. Thorium & 214. Silver \\
2. Lead & 53. Nickel & 109. Barium & 219. Antimony \\
3. Mercury & 74. Zinc & 117. Manganese & \\
7. Cadmium & 77. Chromium & 128. Copper & \\
42. Beryllium & 98. Uranium & 198. Vanadium & \\
\hline \multicolumn{4}{c}{ Halogenated organic compounds } \\
5. Polychlorinated biphenyls & 21. p,p'-DDE & 64. trans-Chlordane & 171. Oxychlordane \\
12. p, $p^{\prime}$-DDT & 25. p, $p^{\prime}$-DDD & 93. Hexachlorobenzene & \\
17. Dieldrin & 57. Endosulfan I & 127. Chlorpyrifos & \\
20. Chlordane & 59. cis-Chlordane & 150. Trifluralin & \\
\hline & \multicolumn{1}{c}{ Polycyclic aromatic hydrocarbons } & 253. Pyrene \\
\hline 8. Polycyclic aromatic hydrocarbons & 39. Benzo(a)anthracene & 137. Chrysene & \\
9. Benoz(a)pyrene & 62. Benzo(k)fluoranthene & 161. Acenaphthene & \\
10. Benzo(b)fluoranthene & 78. Naphthalene & 174. Indenopyrene & \\
15. Dibenzo(a,h)anthracene & 110. Fluoranthene & 246. Pheananthrene & \\
\hline
\end{tabular}

The U.S. Geological Survey (USGS), in cooperation with the San Antonio River Authority and the San Antonio Metropolitan Health District Public Center for Environmental Health, completed a reconnaissance-level investigation of the contaminants in sediment samples collected from selected streams in Bexar County during 2007-09. The investigation was designed to enable decision-makers to determine which watershed areas have contaminants in streambed sediments at concentrations of concern, to assess which contaminants need further study, and to provide information on the sources and transport of sediment-associated contaminants in streams in Bexar County that drain to the San Antonio River. Investigations of the relations of sediment-contaminant concentrations to sediment-quality guidelines, possible sources of contamination, and land use, such as the investigation documented by this report, also can provide insight into the types of sediment-bound contaminants that are or might become of concern to aquatic life and human health (Mahler and others, 2006). The land use of the runoff-contributing areas (hereinafter, contributing areas) for each site in Bexar County where sediment samples were collected during 2007-09 varies considerably (detailed land-use data were only available in Bexar County [Steve Gonzales, San Antonio River Authority, written commun., 2005]), so only land use in Bexar County was considered. The municipal boundary of San Antonio is entirely in Bexar County (fig. 1). Some of the contributing areas in Bexar County are largely urbanized (Leon Creek, Salado Creek, and San Antonio River) and others less so (Medio Creek, Medina River, Elm Creek, Martinez Creek, and Chupaderas Creek) (fig. 2; table 2). The less developed contributing areas provide information on regional background concentrations.

\section{Purpose and Scope}

This report describes an assessment of the concentrations of selected hydrophobic contaminants (trace elements, halogenated organic compounds, and PAHs) in streambed-sediment and suspended-sediment samples collected from sites on eight streams (Medio Creek, Medina River, Elm Creek, Martinez Creek, Chupaderas Creek, Leon Creek, Salado Creek, and San Antonio River) in Bexar County during 2007-09. Observations are made about the occurrence and distribution of trace elements and organic compounds measured in Bexar County during 2007-09, including comparisons of trace element and organic contaminant concentrations among watersheds or site contributing areas and between streambed- and suspended-sediment samples. The frequencies with which the halogenated organic compounds were detected in streambedand suspended-sediment samples are assessed.

Trace element and organic compound concentrations measured in Bexar County during 2007-09 (appendixes 1.1, 1.2, and 1.3) are compared to sediment-quality guidelines; they are also compared to the results of previous studies by the USGS in Bexar County (1995-2001), to the results from streambed-sediment samples collected from eight U.S. Air Force Center for Engineering and the Environment (AFCEE) sampling sites during 1994-2008, and to sediment-associated constituents measured in sediment samples collected during 
Introduction

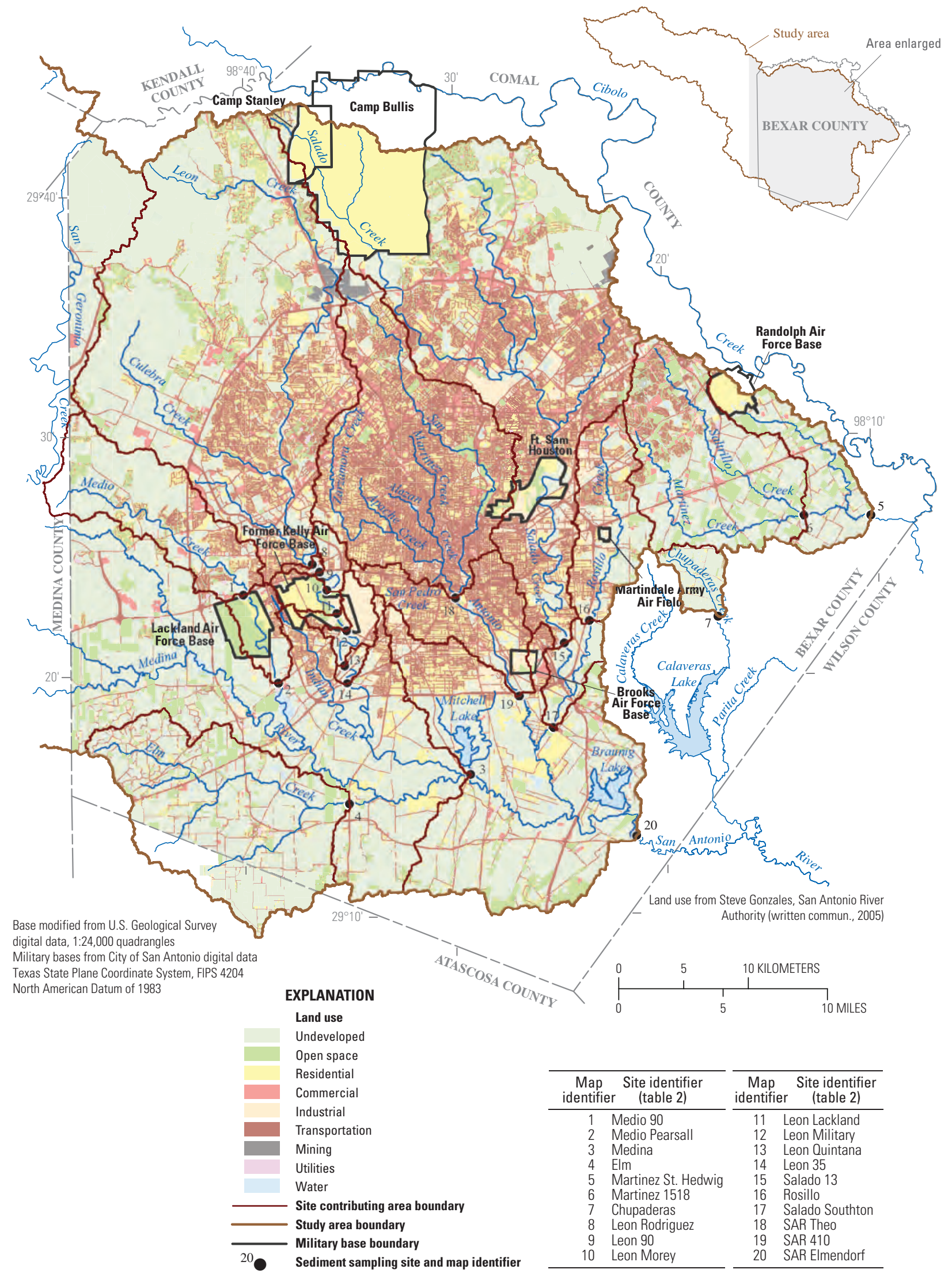

Figure 2. Land use in associated contributing area of each site where streambed-sediment and suspended-sediment samples were collected in Bexar County, Texas, 2007-09. 
Table 2. Characteristics of associated contributing area of each site where streambed-sediment and suspended-sediment samples were collected in Bexar County, Texas, 2007-09.

[km², square kilometers; --, not applicable]

\begin{tabular}{|c|c|c|c|c|c|c|c|c|c|c|c|c|c|c|}
\hline \multirow[b]{2}{*}{$\begin{array}{l}\text { U.S. Geological Survey station } \\
\text { number and name }\end{array}$} & \multirow{2}{*}{$\begin{array}{c}\text { Map } \\
\text { identi- } \\
\text { fier } \\
\text { (figs. 1, } \\
2,4,14 \text { ) }\end{array}$} & \multirow[b]{2}{*}{$\begin{array}{c}\text { Site } \\
\text { identifier }\end{array}$} & \multirow{2}{*}{$\begin{array}{c}\text { Site } \\
\text { contri- } \\
\text { buting } \\
\text { area }^{1} \\
\left(\mathrm{~km}^{2}\right)\end{array}$} & \multirow[b]{2}{*}{$\begin{array}{c}\text { Popu- } \\
\text { lation }^{2} \\
\text { (per } \\
\text { km²) }\end{array}$} & \multicolumn{9}{|c|}{ Land-use category ${ }^{3}$ (percent) } & \multirow{2}{*}{$\begin{array}{l}\text { Percent of } \\
\text { contributing } \\
\text { area with } \\
\text { available } \\
\text { land-use } \\
\text { data }\end{array}$} \\
\hline & & & & & $\begin{array}{c}\text { Un- } \\
\text { devel- } \\
\text { oped }\end{array}$ & $\begin{array}{l}\text { Open } \\
\text { space }\end{array}$ & $\begin{array}{c}\text { Resi- } \\
\text { dential }\end{array}$ & $\begin{array}{l}\text { Com- } \\
\text { mer- } \\
\text { cial }\end{array}$ & $\begin{array}{c}\text { Indus- } \\
\text { trial }\end{array}$ & $\begin{array}{c}\text { Trans- } \\
\text { por- } \\
\text { tation }\end{array}$ & $\begin{array}{c}\text { Min- } \\
\text { ing }\end{array}$ & $\begin{array}{l}\text { Utili- } \\
\text { ties }\end{array}$ & Water & \\
\hline $\begin{array}{l}08180740 \text { Medio Creek at U.S. Highway 90, San Antonio, } \\
\text { Tex. }\end{array}$ & 1 & Medio 90 & 100 & 453 & 66.0 & 4.7 & 17.8 & 2.8 & 0.59 & 7.7 & 0 & 0.23 & 0.22 & 93 \\
\hline $\begin{array}{l}08180750 \text { Medio Creek at Pearsall Road, San Antonio, } \\
\text { Tex. }\end{array}$ & 2 & Medio Pearsall & 123 & 425 & 58.1 & 11.9 & 18.1 & 2.5 & 1.5 & 7.5 & 0 & .19 & .25 & 94 \\
\hline 08181500 Medina River at San Antonio, Tex. & 3 & Medina & 3,368 & 112 & 65.7 & 7.3 & 14.4 & 2.2 & 2.6 & 6.7 & .25 & .11 & .72 & 37 \\
\hline $\begin{array}{l}08180840 \text { Elm Creek at State Highway 16, San Antonio, } \\
\text { Tex. }\end{array}$ & 4 & Elm & 195 & 54 & 79.2 & 8.7 & 4.9 & .79 & .39 & 4.9 & 0 & .16 & 1.0 & 78 \\
\hline 08185100 Martinez Creek near St. Hedwig, Tex. & 5 & $\begin{array}{l}\text { Martinez St. } \\
\text { Hedwig }\end{array}$ & 210 & 329 & 58.1 & 16.8 & 12.0 & 2.7 & .64 & 8.1 & 0 & .42 & 1.2 & 100 \\
\hline $\begin{array}{l}08185095 \text { Martinez Creek at Farm Road } 1518 \text { near St. } \\
\text { Hedwig, Tex. }\end{array}$ & 6 & Martinez 1518 & 152 & 415 & 54.9 & 17.6 & 11.0 & 3.5 & .81 & 10.2 & 0 & .56 & 1.4 & 100 \\
\hline $\begin{array}{l}08182410 \text { Chupaderas Creek at State Road } 106 \text { near San } \\
\text { Antonio, Tex. }\end{array}$ & 7 & Chupaderas & 19 & 61 & 83.6 & 5.0 & 5.0 & .46 & .46 & 3.0 & 0 & .11 & 2.5 & 100 \\
\hline $\begin{array}{l}292443098364600 \text { Leon Creek at Rodriguez Park, San } \\
\text { Antonio, Tex. }\end{array}$ & 8 & Leon Rodriguez & 488 & 422 & 58.4 & 5.6 & 21.3 & 3.7 & 1.6 & 8.4 & .64 & .10 & .24 & 100 \\
\hline $\begin{array}{l}\text { 08181445 Leon Creek at State Highway 90, San Antonio, } \\
\text { Tex. }\end{array}$ & 9 & Leon 90 & 491 & 424 & 58.3 & 5.5 & 21.4 & 3.7 & 1.6 & 8.5 & .64 & .10 & .23 & 100 \\
\hline $\begin{array}{l}292338098360501 \text { Leon Creek at Morey Road, San } \\
\text { Antonio, Tex. }\end{array}$ & 10 & Leon Morey & 500 & 422 & 58.0 & 5.6 & 21.2 & 3.6 & 1.9 & 8.6 & .63 & .10 & .23 & 100 \\
\hline $\begin{array}{l}292240098353600 \text { Leon Creek at Lackland Air Force Base } \\
\text { golf course, San Antonio, Tex. }\end{array}$ & 11 & Leon Lackland & 513 & 434 & 56.7 & 6.0 & 22.1 & 3.6 & 2.1 & 8.5 & .61 & .10 & .24 & 100 \\
\hline $\begin{array}{l}292156098350900 \text { Leon Creek at Southwest Military } \\
\text { Drive, San Antonio, Tex. }\end{array}$ & 12 & Leon Military & 517 & 440 & 56.3 & 6.2 & 22.2 & 3.6 & 2.3 & 8.5 & .61 & .10 & .24 & 100 \\
\hline $\begin{array}{l}292029098351400 \text { Leon Creek at Quintana Road, San } \\
\text { Antonio, Tex. }\end{array}$ & 13 & Leon Quintana & 532 & 433 & 55.3 & 6.0 & 21.7 & 3.5 & 4.2 & 8.4 & .59 & .09 & .24 & 100 \\
\hline $\begin{array}{l}08181480 \text { Leon Creek at Interstate Highway 35, San } \\
\text { Antonio, Tex. }\end{array}$ & 14 & Leon 35 & 536 & 429 & 55.3 & 6.0 & 21.6 & 3.5 & 4.3 & 8.5 & .58 & .09 & .25 & 100 \\
\hline 08178800 Salado Creek at Loop 13, San Antonio, Tex. & 15 & Salado 13 & 479 & 616 & 28.2 & 4.8 & 43.3 & 4.8 & 6.0 & 12.0 & .44 & .09 & .27 & 100 \\
\hline $\begin{array}{l}08178825 \text { Rosillo Creek at New Sulphur Springs Road, } \\
\text { San Antonio, Tex. }\end{array}$ & 16 & Rosillo & 70 & 657 & 41.0 & 3.8 & 24.6 & 4.6 & 11.9 & 13.5 & 0 & .19 & .34 & 100 \\
\hline $\begin{array}{l}08178830 \text { Salado Creek at Southton Road, San Antonio, } \\
\text { Tex. }\end{array}$ & 17 & Salado Southton & 571 & 602 & 31.6 & 4.7 & 39.6 & 4.7 & 6.6 & 12.1 & .37 & .10 & .29 & 100 \\
\hline $\begin{array}{l}08178505 \text { San Antonio River at Theo Avenue, San } \\
\text { Antonio, Tex. }\end{array}$ & 18 & SAR Theo & 229 & 1768 & 6.1 & 3.1 & 50.9 & 7.3 & 5.3 & 25.7 & 1.18 & .04 & .23 & 100 \\
\hline $\begin{array}{l}08178565 \text { San Antonio River at Loop 410, San Antonio, } \\
\text { Tex. }\end{array}$ & 19 & SAR 410 & 297 & 1765 & 7.0 & 2.5 & 51.1 & 6.1 & 6.3 & 25.7 & .91 & .03 & .20 & 100 \\
\hline 08181800 San Antonio River near Elmendorf, Tex. & 20 & SAR Elmendorf & 4,508 & 290 & 49.9 & 5.9 & 25.1 & 3.2 & 4.1 & 10.5 & .33 & .10 & .93 & 53 \\
\hline Median & & & 483 & 427 & 56.5 & 5.7 & 21.5 & 3.5 & 2.2 & 8.5 & .40 & .10 & .25 & -- \\
\hline
\end{tabular}


previous studies in the Austin and Fort Worth, Tex., areas. Inferences concerning potential sources of the contaminants measured in the eight watersheds where samples were collected are made by analyzing potential sources of contamination and land use in the contributing area for each samplecollection site in Bexar County by evaluating trace element and organic compound concentrations with statistical analyses, including:

- Similarity of or difference between contaminant concentration by watershed;

- Relations between land use and potential sources of contaminants measured in streambed- and suspendedsediment samples; and

- A preliminary evaluation of possible sources of the PCBs and PAHs measured in streambed-sediment samples.

\section{Description of Study Area}

The study area consists of the cumulative drainage areas (watersheds) for eight streams where streambed- and suspended-sediment sites were sampled in Bexar County during 2007-09 (fig. 1). The sampling sites are located in the contributing areas of the following eight streams: Medio Creek, Medina River, Elm Creek, Martinez Creek, Chupaderas Creek, Leon Creek, Salado Creek, and San Antonio River. The sum of all contributing areas for sites on a given stream is considered the watershed for that stream. The watersheds for the sampling sites compose most of Bexar County, as well as parts of adjacent counties to the west and north (fig. 1). Most of the urban development in the study area has occurred in Bexar County where San Antonio is located. For each sampling site, the part of the contributing area located in Bexar County is delineated in figure 2. Characteristics of the contributing area for each sampling site such as size, population density, land use (table 2), and potential sources of contamination vary widely. Most contributing areas in the study area drain to the downstream-most sampling site on the San Antonio River (USGS station 08181800 San Antonio River near Elmendorf, Tex.) (hereinafter, SAR Elmendorf site [fig. 2, map identifier 20]). Martinez Creek is the easternmost stream of the eight major streams in the study area sampled for this study and the only stream that does not contribute flow directly to the San Antonio River. Martinez Creek in eastern Bexar County drains toward the east into Cibolo Creek, which flows into the San Antonio River north of Karnes City, Tex. (approximately 90 kilometers [km] southeast of San Antonio). The population density and percentages of residential, commercial, and industrial land use are lowest in the Elm Creek and Chupaderas Creek contributing areas and highest in the Salado Creek and San Antonio River contributing areas (table 2). Population density and percentages of residential, commercial, and industrial land use in the Leon Creek contributing area are typical (near the median) for the study area in Bexar County.
There are several military installations in Bexar County, and the land use for each military installation includes a mixture of undeveloped, residential, commercial, industrial, and open space (fig. 2). The Camp Bullis Military Training Reservation in northern Bexar County is in the contributing area of USGS station 08178800 Salado Creek at Loop 13, San Antonio, Tex. (hereinafter, Salado 13 site [fig. 2, map identifier 15]). When Loop 13 was built, much of the road incorporated parts of the older Southwest Military Drive, and official station names in the USGS National Water Information System (NWIS) (U.S. Geological Survey, 2011) refer to Loop 13 or Southwest Military Drive depending on when the station was installed (A.M. Miller, U.S. Geological Survey, oral commun., 2011). The former Kelly Air Force Base (AFB), which was decommissioned in 2001, is mostly in the contributing areas of USGS stations 292240098353600 Leon Creek at Lackland AFB golf course, San Antonio, Tex. (hereinafter, Leon Lackland site [fig. 2, map identifier 11]); 292156098350900 Leon Creek at Southwest Military Drive, San Antonio, Tex. (hereinafter, Leon Military site [fig. 2, map identifier 12]); and 292029098351400 Leon Creek at Quintana Road, San Antonio, Tex. (hereinafter, Leon Quintana site [fig. 2, map identifier 13]). Most of Lackland AFB is in the contributing area of USGS station 08180750 Medio Creek at Pearsall Road, San Antonio, Tex. (hereinafter, Medio Pearsall site [fig. 2, map identifier 2]). Randolph AFB is partly in the contributing area of USGS station 08185095 Martinez Creek at Farm Road 1518 near St. Hedwig, Tex. (hereinafter, Martinez 1518 site [fig. 2, map identifier 6]) and partly in the contributing area of USGS station 08185100 Martinez Creek near St. Hedwig, Tex. (hereinafter, Martinez St. Hedwig site [fig. 2, map identifier 5]). Fort Sam Houston is in the contributing area of the Salado 13 site. Brooks AFB is in part of the contributing areas of USGS station 08178565 San Antonio River at Loop 410, San Antonio, Tex. (hereinafter, SAR 410 site [fig. 2, map identifier 19]) and the SAR Elmendorf site.

The locations of floodwater-retention structures in the study area were compiled by the San Antonio River Authority (John Refolo, written commun., 2010). A total of 44 floodwater-retention structures (small dams) on streams are depicted in figure 1. Not all streams and floodwater-retention structures in the study area are depicted; according to the San Antonio River Authority, there are 89 floodwater-retention structures in the study area, many of which are on first-order streams not shown on figure 1 . The floodwater-retention structures trap sediment during stormwater runoff, preventing some of the sediment from being transported downstream.

The Texas Commission on Environmental Quality (TCEQ) is required by the 1996 Safe Drinking Water Act Amendments to assess every public drinking water source for susceptibility to certain chemicals (Texas Commission on Environmental Quality, 2009a). The TCEQ Source Water Assessment Program (SWAP) fulfills that requirement and includes a detailed listing of potential sources of contamination (PSOC) that might affect source waters. Although San Antonio drinking water is not obtained from any of the 
streams in the study area (San Antonio Water System, 2009), the SWAP PSOC list is useful for understanding what chemicals are known to be present in the contributing areas of sites where streambed- and suspended-sediment samples were collected during 2007-09 (fig. 3). The top 10 PSOC categories in the contributing area of each site in Bexar County were identified and ranked on the basis of the standard area of impact (Texas Commission on Environmental Quality, 2009a) designated for each type of PSOC (fig. 3). Abandoned municipal solid-waste landfills and industrial wastewater outfalls are the most common PSOC in all contributing areas in Bexar County. TCEQ determined that the third most prominent PSOC at each site in the Leon Creek contributing areas are active or abandoned mined lands (fig. 3). Plastic manufacturing and sales and septic systems are not shown in figure 3 because of their low occurrence ( 0 to 4 percent for both PSOC categories) in all contributing areas except in the contributing areas of the Medio sites, where plastic manufacturing and sales and septic systems represent 11 to 16 percent of the PSOC categories.

\section{Previous Studies}

The USGS and other Federal agencies and State agencies have assessed the concentrations of various contaminants in Bexar County streams in previous studies. This section provides a brief review of those sampling efforts, the results of which are useful for comparison to the results obtained from samples collected during 2007-09. Samples collected during previous studies were obtained at the same sampling sites used during 2007-09 (or at nearby locations) and were analyzed for the same constituents as the 2007-09 samples.

The USGS collected streambed-sediment samples at the Medio Pearsall site, at USGS station 08181480 Leon Creek at Interstate Highway 35, San Antonio, Tex., (hereinafter, Leon 35 site; [fig. 2, map identifier 14]), and at the Salado 13, SAR 410, and SAR Elmendorf sites between 1995 and 2001. The samples were analyzed for trace elements, halogenated organic compounds, and PAHs. During 1995-97, the USGS collected biological samples (organisms) at the Leon 35, Salado 13, and SAR Elmendorf sites. The organisms were analyzed for trace elements or halogenated organic compounds, or both. Detailed comparisons between previous USGS sampling results and the 2007-09 results are provided in the section of this report entitled "Comparison of Findings to Data from Previous Studies."

In 1982, an Installation Restoration Program (IRP) at Kelly AFB initiated the investigation and cleanup of contaminated sites on the base. The AFCEE oversees compliance sampling of groundwater, Leon Creek surface water, and sediment near the former Kelly AFB, done semiannually as required by TCEQ hazardous waste and permit compliance (Paul Carroll, Department of Defense, Defense Base Closure and Realignment Commission, Environmental Coordinator, personal commun., January 2011). AFCEE sampled 31 sites on Leon Creek during 1994-2008 for streambed sediment; 8 of those 31 sites were selected for comparison to the 2007-09 results on the basis of their proximity to the 7 USGS Leon Creek streambed-sediment sampling sites (fig. 4) and the availability of similar analytical results at the sites. Among the constituents of interest for this report, $p, p^{\prime}$-DDT and PCBs were analyzed in samples from the eight AFCEE sites. Detailed comparisons between the results of semiannual compliance sampling and the present USGS study are provided in the "Comparison of Findings to Data from Previous Studies" section of this report.

The industrial processes associated with military operations at the former Kelly AFB involved many hazardous substances. Industrial wastes entered the environment through leaks, spills, and previously approved disposal practices (U.S. Air Force, 2007). A tier 2 screening level ecological risk assessment (CH2M Hill, 2001) provided descriptions of the historical operations at sites affected by industrial wastes near Leon Creek at the former Kelly AFB. For the assessment, CH2M Hill divided the former Kelly AFB into five areas or zones; Leon Creek flows through or adjacent to zones 1 and 2. Eleven sites in zone 1 and 16 sites in zone 2 were evaluated. Zone 1 included sites used for the disposal of scrap metal, munitions, electroplating sludge, pesticides, and waste petroleum, oil, and lubricants. A waste oil burn pit or chemical disposal pit was also at one of the disposal sites. One site was a sludge spreading area for waste sludge containing high heavy metal concentrations. Zone 2 included a disposal pit for chromium plating sludge and waste; a chemical evaporation pit for disposal of solvents, insecticides, and sludges; two industrial waste treatment plants (IWTPs) that received plating, painting, and degreasing effluents; a liquid incineration site that handled pesticides; an industrial waste lagoon; and a sludge spreading area for wastes from a former IWTP. Many of these sites were regraded (leveled) and filled, capped, or remediated. However, the ecological risk assessment identified the presence of contaminants in surface soils at the affected sites, including trace elements, pesticides, PCBs, and PAHs (CH2M Hill, 2001, appendix $\mathrm{B}$, table 5-3), and migration pathways from the affected sites to Leon Creek, primarily through overland flow associated with storms.

Although the former Kelly AFB receives considerable attention from Federal and State regulatory agencies, in part because fish consumption advisories were issued in 2003 and 2010 (Texas Department of Health, 2003; Texas Department of State Health Services, 2010) for the reach of Leon Creek between State Highway 90 and Loop 13, environmental investigations also have been done at all other military installations in Bexar County. For example, the ATSDR performed a public health assessment in 1998 at Brooks AFB to investigate volatile organic compound (VOC) contamination of groundwater attributed to a fire protection training area. The ATSDR concluded that the groundwater contamination did not present a public health hazard (Agency for Toxic Substances and Disease Registry, 1998). A USEPA facility report on Brooks AFB lists the installation in the Air Facility, (hazardous waste) Biennial Reporters, CERCLA, National Compliance, Resource Conservation and Recovery Act (RCRA), and Safe Drinking 


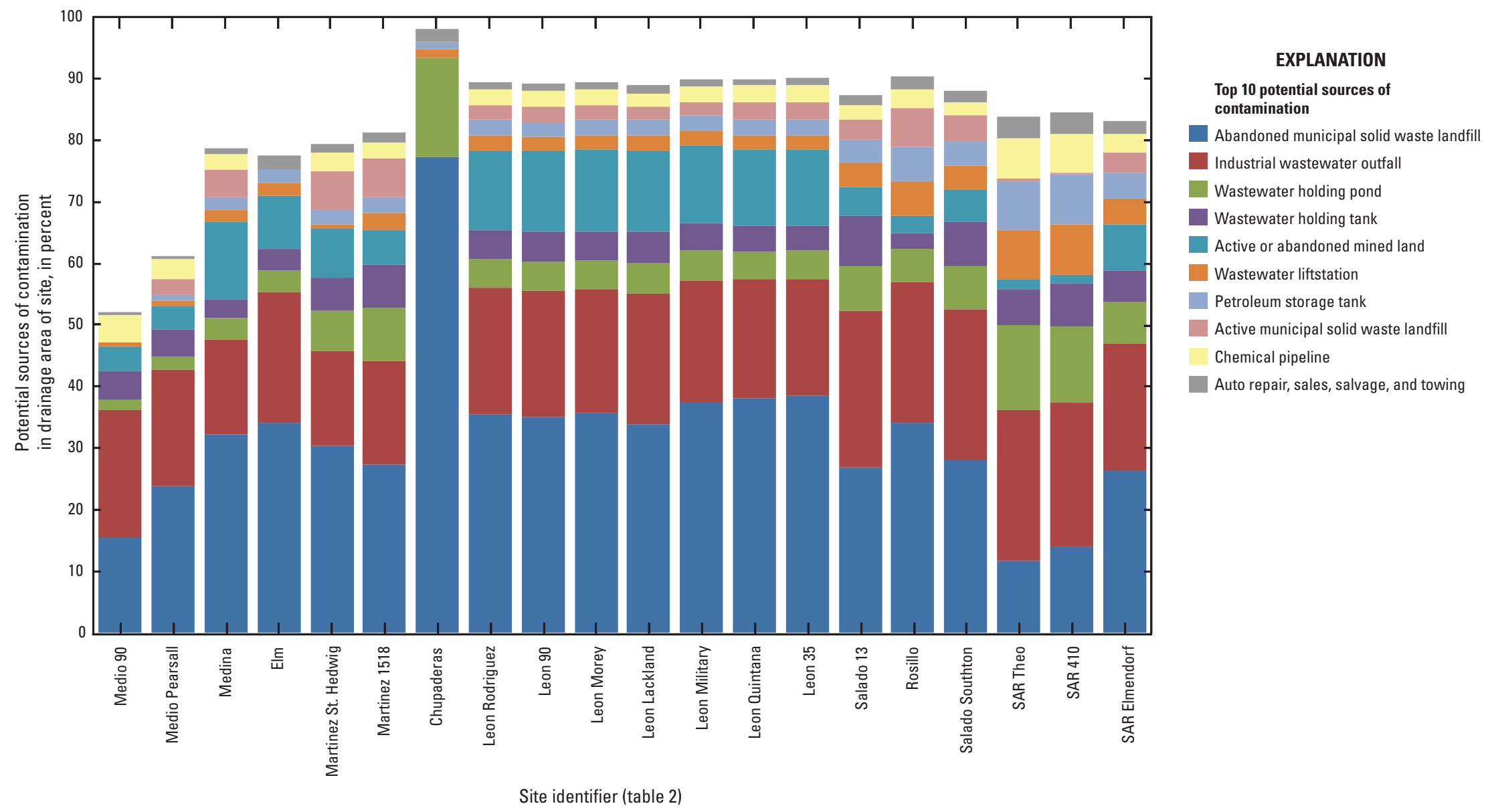

Figure 3. Top 10 potential sources of contamination (Texas Commission on Environmental Quality, 2009a) in contributing areas of sites where streambed-sediment and suspended-sediment samples were collected in Bexar County, Texas, 2007-09. 


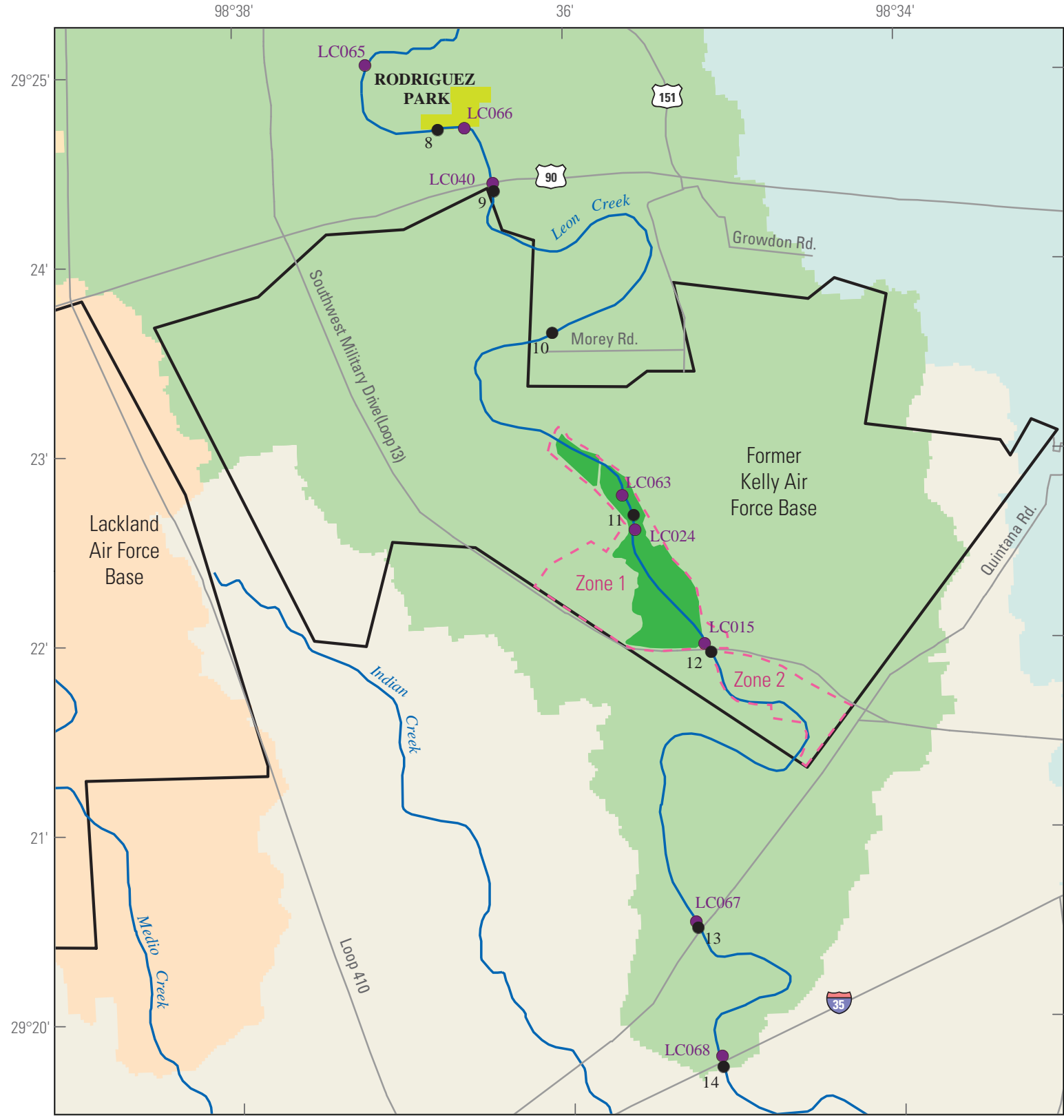

Base modified from U.S. Geological Survey digital data, 1:24,000 quadrangles Military bases and highways from Texas Natural Resources Information System (http://www.tnris.state.tx.us/)

Texas State Plane Coordinate System, FIPS 4204

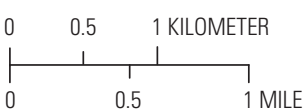

North American Datum of 1983

\section{EXPLANATION}

Medio Creek watershed Medina River watershed Leon Creek watershed San Antonio River watershed Former Kelly Air Force Base golf course

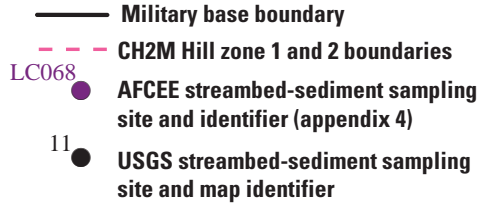

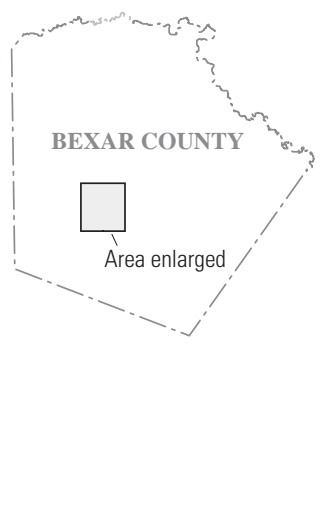

Figure 4. Location of U.S. Air Force Center for Engineering and the Environment (AFCEE) and U.S. Geological Survey (USGS) streambed-sediment sampling sites on Leon Creek, Bexar County, Texas. 
Water information systems (U.S. Environmental Protection Agency, 2011). It is classified as a small-quantity generator of hazardous wastes, producing less than 1,000 kilograms $(\mathrm{kg})$ but more than $100 \mathrm{~kg}$ of hazardous wastes per month. Mostly laboratory wastes and chemicals are products of laboratory test procedures (Brooks Air Force Base, 2000). In 2008, the U.S. Army Environmental Command (2009) evaluated the environmental restoration sites at Camp Bullis and Fort Sam Houston. Camp Bullis environmental restoration activities are being done under the RCRA; Fort Sam Houston environmental restoration activities are being done under the CERCLA and the Clean Water Act (U.S. Army Environmental Command, 2009). The TCEQ is the lead agency for environmental restoration activities at Camp Bullis and Fort Sam Houston. One landfill at Camp Bullis and 11 landfills at Fort Sam Houston are open sites under the IRP. Camp Bullis and Fort Sam Houston each have two munitions sites that are open sites under the Military Munitions Response Program. Additionally, there are three Compliance Cleanup open sites-an open burn/ open detonation site at Camp Bullis, a former dry cleaning facility at Fort Sam Houston, and a newly discovered landfill suspected to contain construction debris at Fort Sam Houston (U.S. Army Environmental Command, 2009). A USEPA facility report on Lackland AFB lists the installation in the Air Facility, CERCLA, Integrated Compliance, National Compliance, National Emissions, RCRA, Safe Drinking Water, and Toxics Release Inventory systems (U.S. Environmental Protection Agency, 2010b). Randolph AFB is listed in the Air Facility, Integrated Compliance, RCRA, Safe Drinking Water, and Toxic Release Inventory information systems (U.S. Environmental Protection Agency, 2010a).

The Texas Department of State Health Services (DSHS) Seafood and Aquatic Life Group (formerly Texas Department of Health Seafood Safety Division) tests for certain contaminants in tissue samples to inform recreational fishermen of possible disease or contamination in fish and other aquatic species. Fish from the San Antonio River were tested in 1998 for trace elements, pesticides, PCBs, semivolatile organic compounds (SVOCs), and VOCs and were determined to pose no apparent public health hazard (Texas Department of State Health Services, 2008). A fish consumption advisory for the lower Leon Creek reach was issued for PCBs in all species of fish on the basis of analytical results from 22 fish skin-off fillet samples obtained from fish collected in 2002 from three sites near sites in this study-USGS station 08181445 Leon Creek at State Highway 90, San Antonio, Tex. (hereinafter, Leon 90 site [fig. 2, map identifier 9]); Leon Lackland (referred to as KAFB by the DSHS); and Leon Military (Texas Department of Health, 2003). The tissues were analyzed for trace elements (no chromium), pesticides, PCBs, SVOCs, and VOCs. At least one contaminant was detected in every sample. Although the concentrations of most constituents were not much larger than the respective laboratory reporting limit (LRL) established by the analytical laboratory for each constituent, concentrations of PCBs in some samples were much greater than the respective LRL.
Mercury, selenium, and zinc were detected (concentrations greater than the respective LRL) in all samples; in contrast, arsenic and lead were not detected (concentrations less than the respective LRL) in any samples. Chlordane and $p, p^{\prime}$-DDE were commonly detected in fish from all three sites. The compound $p, p^{\prime}$-DDT was detected at low concentrations in some samples from a site near the former Kelly AFB golf course. PCBs were detected in fish tissues from all three Leon Creek sites (Leon 90, Leon Lackland, and Leon Military); the most frequent detections and highest PCB concentrations, particularly Aroclor 1260, were detected in samples collected from the Leon Lackland site near the former Kelly AFB golf course (fig. 4). The Texas Department of Health (2003) concluded that all trace element and pesticide concentrations were low, did not exceed the health-based assessment comparison (HAC) values, and were therefore of no toxicological significance, but that consumption of any fish species from Leon Creek at or near the former Kelly AFB golf course poses a public health hazard because the fish might contain unsafe amounts of PCBs.

The DSHS resampled fish in Leon Creek in November 2007 and analyzed skin-off fillet samples from 50 edible fish to assess potential adverse human health effects from consumption of fish from the stream (Texas Department of State Health Services, 2010). The fish were collected during 2007 by the DSHS from five sites where sediment samples were collected by the USGS during 2007-09-USGS station 292443098364600 Leon Creek at Rodriguez Park, San Antonio, Tex. (hereinafter, Leon Rodriguez site [fig. 2, map identifier 8]); Leon 90; Leon Lackland (called KAFB by the DSHS); Leon Quintana (called Ruiz Ranch by the DSHS ); and Leon 35. Analyses included trace elements (no chromium), pesticides, PCB congeners, VOCs, SVOCs, and congeners of polychlorinated dibenzofurans (PCDFs) or dibenzop-dioxins (PCDDs), or both. VOC and SVOC concentrations did not exceed levels of concern (Texas Department of State Health Services, 2010). Copper, lead, mercury, selenium, and zinc were detected (concentrations greater than the respective LRL) in all samples. Arsenic was detected in 31 of 50 fish samples and cadmium was less than the LRL in all samples. In 10 of 50 samples analyzed for pesticides, $p, p^{\prime}$-DDE and chlordane concentrations were greater than the applicable LRL. PCB concentrations greater than the LRL for each congener were detected in all fish tissue samples. PCBs were the only contaminant that equaled or exceeded the HAC values for evaluating systemic (noncancerous) adverse human health effects $\left(\mathrm{HAC}_{\text {noncan }}\right)$ from consumption of fish from Leon Creek. PCB concentrations in fish samples from Leon 90, Leon Lackland (KAFB), Leon Quintana (Ruiz Ranch), and Leon 35 exceeded DSHS guidelines for protection of human health. No trace elements or other organic compounds were detected at concentrations of public health concern (Texas Department of State Health Services, 2010).

Every 2 years, the TCEQ determines if surface-water bodies in Texas are meeting State water-quality standards on the basis of available data and recently reported its findings 
in the "Draft 2010 Texas Integrated Report for Clean Water Act Sections 305(b) and 303(d)" (Texas Commission on Environmental Quality, 2010b), formerly called the "Texas Water Quality Inventory and 303(d) List.” Water bodies that are not meeting the water-quality standards established for their intended use (such as aquatic life, recreation, fish consumption, or general use) are included in the report. Once water bodies are added to the impaired or 303(d) list, the State develops and implements strategies to meet those standards (Texas Commission on Environmental Quality, 2010b). The draft 2010 list of impaired water bodies includes Cibolo Creek from its confluence with the San Antonio River north of Karnes City to a point 100 meters (m) downstream from Interstate Highway 10 in Bexar County. This reach of Cibolo Creek is included because of high levels of bacteria and an impaired fish community; it receives runoff from the contributing areas of the Martinez 1518 and Martinez St. Hedwig sites. Segments of Leon Creek from its confluence with the Medina River to its confluence with Indian Creek are listed as impaired, including the segment extending $3 \mathrm{~km}$ upstream from Highway 353, which is listed as impaired because of low dissolved oxygen concentrations, as are the segment from $3 \mathrm{~km}$ upstream from Highway 353 to U.S. Highway 90 and the segment from $5 \mathrm{~km}$ upstream from the confluence with Medina River to the confluence with Indian Creek. The segment of Leon Creek from $3 \mathrm{~km}$ upstream from Highway 353 to U.S. Highway 90 also is listed as impaired because of PCB detections in edible fish tissue. Salado Creek is listed because of impaired fish and macrobenthic communities, and the San Antonio River upstream from San Pedro Creek is listed because of an impaired fish community. Apache Creek from its confluence with San Pedro Creek to just upstream from its confluence with Zarzamora Creek is listed because of high bacteria levels; Alazan Creek from its confluence with Apache Creek upstream to its confluence with a small tributary named Martinez Creek (different from the Martinez Creek in eastern Bexar County from which samples were collected) and San Pedro Creek from its confluence with the San Antonio River to its confluence with Apache Creek also are listed because of high bacteria levels. These three streams are new additions to the draft 2010 list of impaired water bodies since the last list was prepared in 2008 (Texas Commission on Environmental Quality, 2010b). Apache, Alazan, and San Pedro Creeks are tributaries to the San Antonio River upstream from USGS station 08178505 San Antonio River at Theo Avenue, San Antonio, Tex. (hereinafter, SAR Theo site [fig. 2, map identifier 18]). These impairments were attributed to non-point, unknown point, or unknown sources; loss of riparian habitat; dams or impoundments; or habitat modification (Texas Commission on Environmental Quality, 2010b). Medio Creek, Medina River, and Rosillo Creek (fig. 1) were evaluated but not listed. Concerns noted but not on the 303(d) list are measurable cadmium and silver concentrations in Leon Creek sediment from its confluence with the Medina River to its confluence with Indian Creek (Texas Commission on Environmental Quality, 2010b).

\section{Methods}

The USGS periodically collected surficial streambedsediment samples during base flow and suspended-sediment samples during periods of stormwater runoff from selected streams. The collection of streambed-sediment samples was based on methods of the USGS National Water-Quality Assessment (NAWQA) program (Shelton and Capel, 1994). The NAWQA streambed-sediment collection guidelines recommend collecting fine-grained particulates from 5 to 10 depositional zones along a stream reach about $100 \mathrm{~m}$ in length, however 2 to 5 depositional zones along stream reaches ranging from 60 to $500 \mathrm{~m}$ in length were sampled in Bexar County during 2007-09 (table 3) because many suitable depositional zones were too deeply inundated with water to wade, too widely spaced along the stream reach, inaccessible because of thick vegetation or steep banks, or in access-restricted parts of military installations.

When possible, sites where the USGS collected samples during 2007-09 were at or near previous sediment or biological sampling locations and at existing USGS streamflowgaging stations. The streambed-sediment sampling sites were located along stream reaches with several depositional zones that could be readily sampled by wading the stream. All sites were required to be underwater during sampling because comparability of wet to dry sediment chemistry is unreliable, especially for organic compounds (Shelton and Capel, 1994). Furthermore, the site locations were selected on the basis of their physical accessibility by field personnel.

The amount of urban development differs among contributing areas in Bexar County for each of the eight streams. Urban development is greater in the contributing areas for Leon Creek, Salado Creek, and San Antonio River compared to the contributing areas for Medio Creek, Medina River, Elm Creek, Martinez Creek, and Chupaderas Creek. Streambed- and suspended-sediment samples were collected more frequently from sites in the more developed contributing areas compared to sites in the less developed contributing areas. Two or more streambed-sediment sampling sites were selected in the contributing areas of each of the eight streams in Bexar County and their major tributaries, with the following exceptions: One site on Elm Creek (USGS station 08180840 Elm Creek at State Highway 16, San Antonio, Tex. [hereinafter, Elm site; fig. 2, map identifier 4]); one site on the Medina River downstream from Elm Creek (USGS station 08181500 Medina River at San Antonio, Tex. (hereinafter, Medina site; fig. 2, map identifier 3]); and one site on Chupaderas Creek (USGS station 808182410 Chupaderas Creek at State Road 106 near San Antonio, Tex. [hereinafter, Chupaderas site; fig. 2, map identifier 7]). Calaveras Creek was considered for sampling but was dry during field reconnaissance. Five biological-monitoring sites and numerous existing streambedsediment sampling sites on Leon Creek were sampled semiannually for AFCEE compliance (for example, $\mathrm{CH} 2 \mathrm{M}$ Hill, 1999) for regulatory (compliance-monitoring) purposes (fig. 4); locations of existing sampling sites on Leon 
Table 3. Streambed-sediment and suspended-sediment samples collected in contributing areas of sites in Bexar County, Texas, 2007-09.

[Shading indicates streambed-sediment sample; $\mathrm{X}$ indicates large-volume suspended-sediment sample]

\begin{tabular}{|c|c|c|c|c|c|c|}
\hline \multirow{2}{*}{$\begin{array}{l}\text { Map identifier } \\
\text { (figs. 1, 2, 4, 14) }\end{array}$} & \multirow{2}{*}{$\begin{array}{l}\text { Site identifier } \\
\text { (table 2) }\end{array}$} & \multirow{2}{*}{$\begin{array}{l}\text { Length of reach } \\
\text { (meters) }\end{array}$} & \multirow{2}{*}{$\begin{array}{c}\text { Number of } \\
\text { depositional } \\
\text { zones }^{1}\end{array}$} & \multicolumn{3}{|c|}{ Collection of samples } \\
\hline & & & & 2007 & 2008 & 2009 \\
\hline 1 & Medio 90 & 170 & 3 & & & \\
\hline 2 & Medio Pearsall & 160 & 3 & & & \\
\hline 3 & Medina & 130 & 4 & & $\mathrm{X}$ & \\
\hline 4 & Elm & 60 & 3 & & & \\
\hline 5 & Martinez St. Hedwig & 90 & 5 & & $\mathrm{X}$ & $\mathrm{X}$ \\
\hline 6 & Martinez 1518 & 100 & 3 & & & \\
\hline 7 & Chupaderas & 90 & 4 & & & \\
\hline 8 & Leon Rodriguez & 190 & 3 & & & \\
\hline 9 & Leon 90 & 180 & 3 & & & \\
\hline 10 & Leon Morey & 230 & 5 & & & \\
\hline 11 & Leon Lackland & 500 & 4 & & & \\
\hline 12 & Leon Military & 100 & 3 & & & \\
\hline 13 & Leon Quintana & 180 & 4 & & & \\
\hline 14 & Leon 35 & 160 & 4 & & $\mathrm{X}$ & $\mathrm{X}$ \\
\hline 15 & Salado 13 & 90 & 3 & & & \\
\hline 16 & Rosillo & 190 & 5 & & & \\
\hline 17 & Salado Southton & 130 & 4 & & $\mathrm{X}$ & $\mathrm{X}$ \\
\hline 18 & SAR Theo & 100 & 3 & & & \\
\hline 19 & SAR 410 & 260 & 4 & & $\mathrm{X}$ & \\
\hline 20 & SAR Elmendorf & 190 & 2 & & $\mathrm{X}$ & $\mathrm{X}$ \\
\hline
\end{tabular}

${ }^{1}$ Streambed-sediment sample for each site composited from multiple depositional zones within a single stream reach.

Creek were used to help determine the locations of sites on Leon Creek that were sampled during 2007-09. The Leon Rodriguez site was the most upstream site sampled for streambed sediments during 2007-09; Leon Creek upstream from the Leon Rodriguez site is usually dry except immediately after a storm. The SAR Theo site was sampled only one time because construction of bank-retention walls and other channel improvements began at the site after the first sample was collected, disturbing the soils and sediments in the stream channel (Brian Petri, U.S. Geological Survey, written commun., 2007).

In addition to collecting streambed-sediment samples, large-volume suspended-sediment (LVSS) samples were collected at selected sites. LVSS samples were collected from the downstream-most sites on Martinez Creek (Martinez St. Hedwig site), Leon Creek (Leon 35 site), and Salado Creek (USGS station 08178830 Salado Creek at Southton Road, San Antonio, Tex. [hereinafter, Salado Southton site; fig. 2, map identifier 17), from the SAR 410 and SAR Elmendorf sites on the San Antonio River, and from the Medina site on the Medina River (fig. 1; table 3). The LVSS sampler was installed at the SAR 410 site upstream from where the Medina River and Salado Creek flow into the San Antonio River (fig. 1).

\section{Sample Collection}

The location of each sampling site was documented by using a global positioning system (GPS), digital photographs, and field notes to describe the site relative to surrounding landmarks, as well as plotting the site on USGS quadrangle maps or smaller scale site maps when necessary. Streambedsediment and LVSS samples were collected more frequently at sites with more developed contributing areas (sites on Leon Creek, Salado Creek, and San Antonio River) compared with sites with less development in their contributing areas (sites on Medio Creek, Medina River, Elm Creek, Martinez Creek, and 
Chupaderas Creek) (fig. 2). The LVSS samples were collected at some sites that were active USGS streamflow-gaging stations (Medina, Martinez St. Hedwig, Leon 35, SAR 410, and SAR Elmendorf sites). The number of depositional zones, type of sample, and year of sample collection at each site are shown in table 3.

Sampling began in November 2007 and was completed in August 2009. Streambed-sediment samples were collected during November and December 2007; February, March, April, and August 2008; and August 2009. LVSS samples were retrieved after rainfall caused sufficient runoff for sampling, which varied depending on the site. LVSS samples were collected in July and August 2008, and March and May 2009 (fig. 5). Fewer LVSS samples were collected than originally planned because relatively few storms resulted in sufficient runoff for sampling during the study period. Figure 5 shows rainfall for National Weather Service cooperative station 417945 San Antonio International Airport during November 2007-August 2009.

\section{Streambed-Sediment Samples}

Streambed-sediment samples were composited from multiple depositional zones within a single stream reach at each site (table 3). The smallest number of depositional zones sampled was two zones at the SAR Elmendorf site, where field personnel were only able to access areas of thick deposits of fine-grained sediment near the banks. Five zones each were sampled at the Martinez St. Hedwig site, one site on Leon Creek (USGS station 292338098360501 Leon Creek at Morey Road, San Antonio, Tex., [hereinafter, Leon Morey site; fig. 2, map identifier 10]), and one site in the Salado Creek watershed (USGS station 08178825 Rosillo Creek at New Sulphur Springs Road, San Antonio, Tex. [hereinafter, Rosillo site; fig. 2, map identifier 16]), where the depositional zones were small and had small amounts of fine-grained surficial sediments. All sediment samples were collected by wading the stream; each depositional zone was approached by one or two field personnel at a time from the downstream direction so as not to disturb the streambed sediment. The GPS coordinates of each depositional zone sampled were recorded. After rinsing the sampling equipment with native water, two scoops of the surficial streambed sediment were collected from smaller depositional zones and three scoops were collected from larger depositional zones and composited in a glass bowl. The total volume of streambed sediment collected at each stream reach was about 1 liter (L) (wet).

Streambed-sediment samples were processed either in the field or in the laboratory of the USGS Texas Water Science Center, San Antonio office. Samples not processed in the field were stored on ice immediately after collection until processed later in the laboratory. Samples were mixed and then sieved to reduce grain-size variability thus allowing for more informative comparisons among samples.

Trace element concentrations measured in streambedsediment samples were not normalized by grain size; these samples were sieved to a uniform grain size. About one-half of the sample was sieved with a 63-micrometer $(\mu \mathrm{m})$ nyloncloth sieve for analysis of major and trace elements. Sediment greater than $63 \mu \mathrm{m}$ (the diameter differentiating larger sand size particles from smaller clay and silt size particles) was discarded. The fine material (less than $63 \mu \mathrm{m}$ ) was transferred into 125-milliliter $(\mathrm{mL})$ polypropylene jars that were placed on ice and transported to the local USGS laboratory in San Antonio. The samples were then transported on ice to the USGS Texas Water Science Center, Austin office; freeze-dried and pulverized; and shipped to the USGS Mineral Resources Program Analytical Laboratories in Lakewood, Colo., for analysis. The remaining part of the sample that was not analyzed for major and trace elements was sieved with a 2.0-millimeter (mm) stainless-steel mesh sieve on the opening of a 500-mL pre-cleaned glass jar and analyzed for organic compounds. Coarse sediment (greater than $2.0 \mathrm{~mm}$ ) was discarded. The samples for organic compound analyses were stored chilled in the same manner as samples for major and trace element analysis and similarly shipped on ice to the USGS National Water Quality Laboratory (NWQL) in Lakewood, Colo., for analysis.

\section{Large-Volume Suspended-Sediment Samples}

LVSS samples were collected to investigate the occurrence and distribution of sediment contaminants in stormwater; sample collection followed the methods of Mahler and Van Metre (2003) and Van Metre and others (2003). As stormwater runoff enters streams, the stage, discharge, suspended-sediment concentration (SSC), and turbidity all increase (Curriero and others, 2001; Mahler and others, 2006). Analysis of constituents sorbed to particulates in the streamflow containing stormwater runoff provides information on transport of sediment-associated constituents (Larson and others, 2010). LVSS samples were collected with passive samplers (fig. 6) that filled once the stage of the stream increased to a predetermined threshold as a result of stormwater runoff. Once the carboy was full, no more water entered the carboy, resulting in a sample from the rising limb of the hydrograph (also referred to as a first-flush sample). The LVSS passive samplers consisted of a 25-L polyethylene sample bottle inside a cylindrical steel housing installed near the stream channel (fig. 6). Each sampler had two water intake nozzles pointed upstream and an air vent line designed to passively collect first-flush grab samples at the sampling sites when the stream depth increased and inundated the intake nozzles. Intake nozzles were about $0.6 \mathrm{~m}$ above the bottom of the cylinder. The amount of flow required to collect a sample varied by site. The air vent line allowed air in the bottle to leave as water flowed in and blocked outflow when the bottle was full so that water did not continue to cycle through the bottle. After the storm passed and streamflow receded, the LVSS sample was removed from the sampler and transported to the laboratory at the USGS Austin or San Antonio office for processing. 


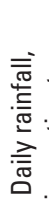

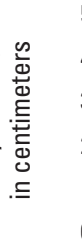

National Weather Service cooperative station 417945

- San Antonio International Airport, San Antonio, Tex.

- (National Oceanic and Atmospheric Administration, 2010)

-

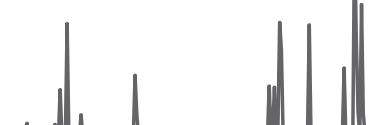

لس لل

.
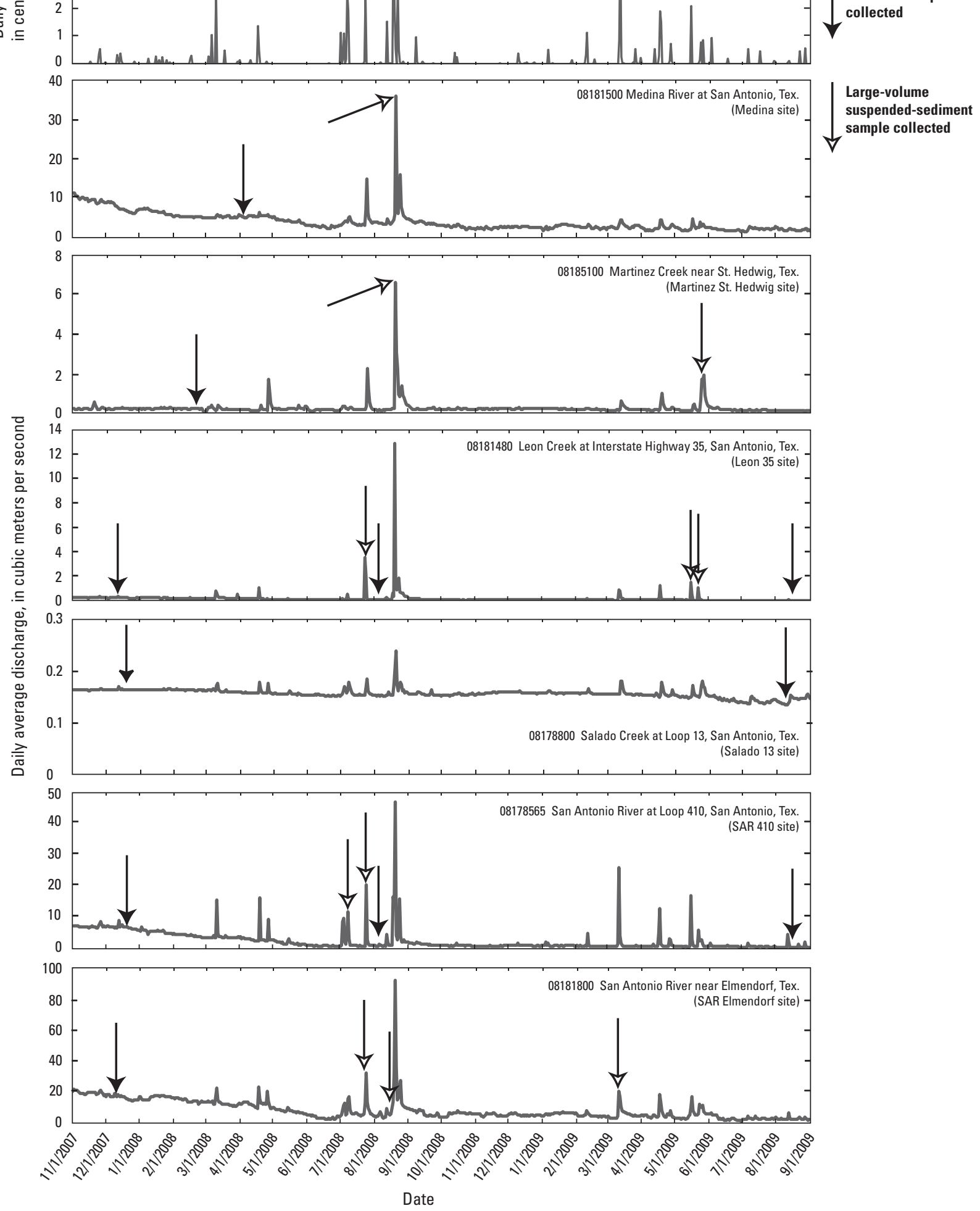

Figure 5. Hyetograph showing rainfall at San Antonio International Airport and hydrographs showing stream discharge and streambed-sediment and suspended-sediment sampling at selected sites in Bexar County, Texas, 2007-09. 
$\boldsymbol{A}$

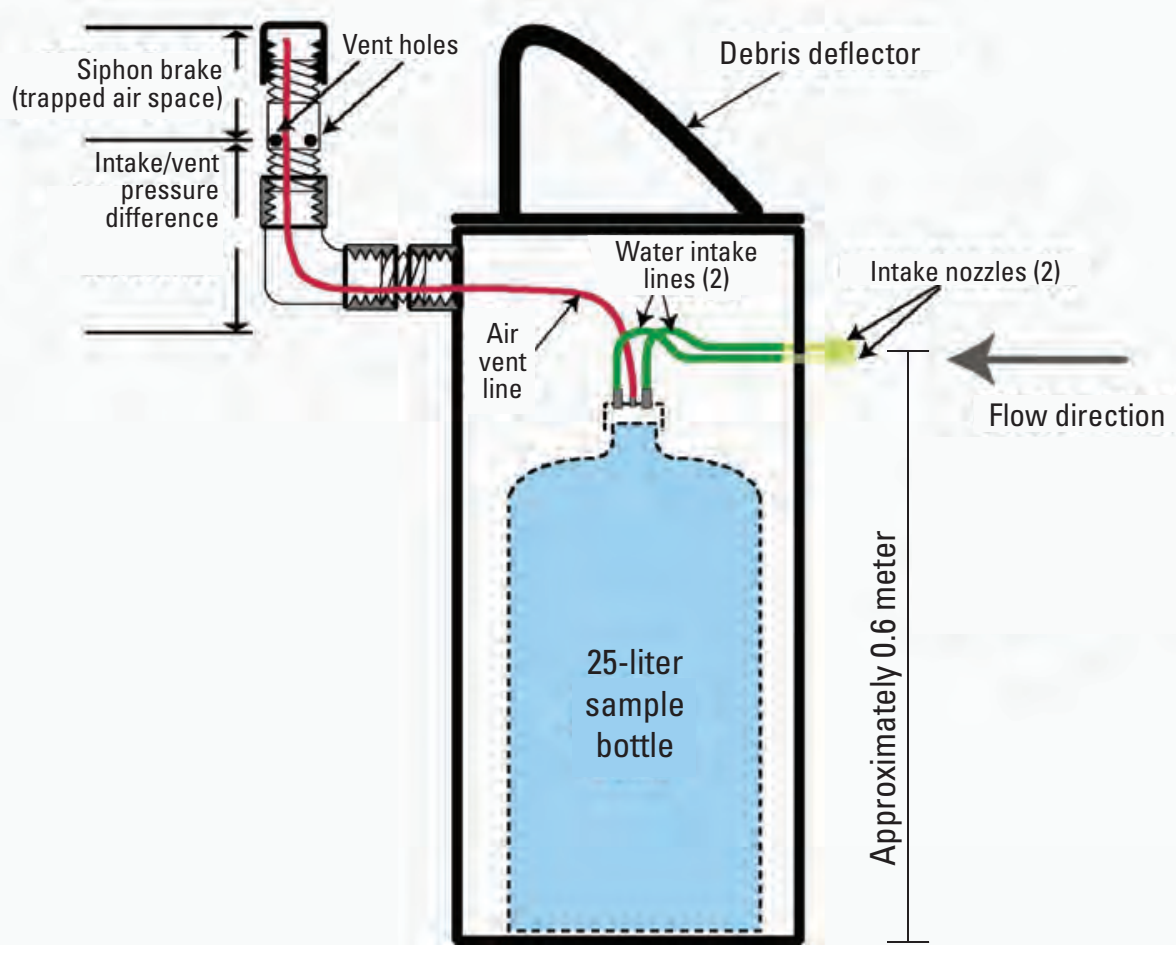

B

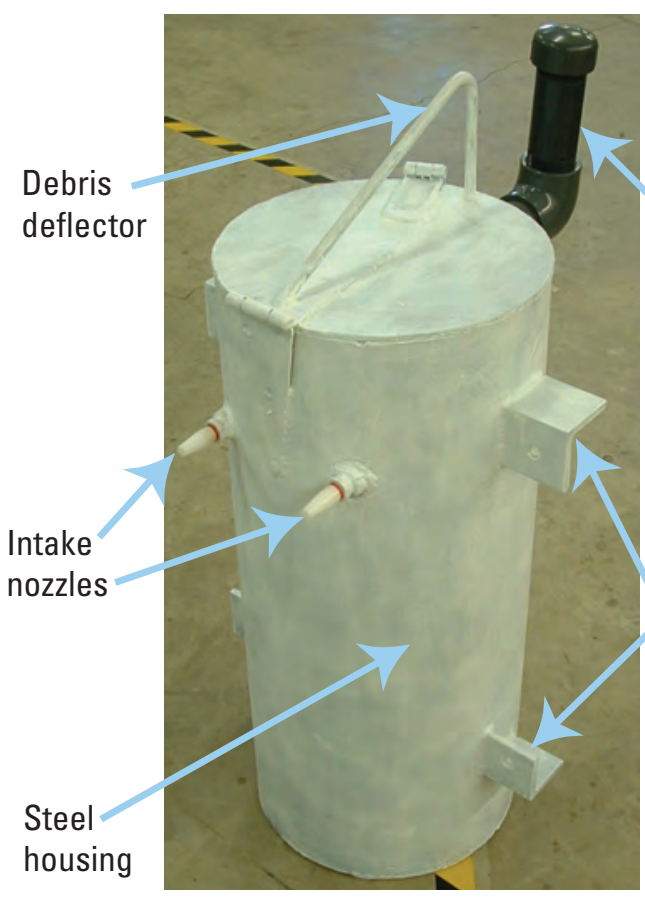

C

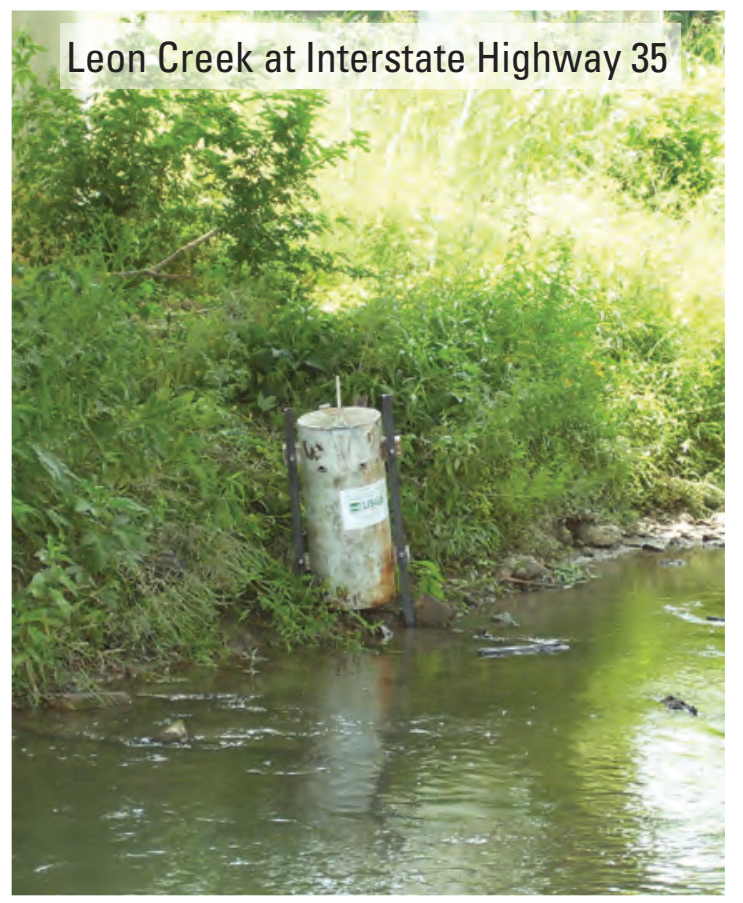

Figure 6. Schematic $(A)$ and photographs (B and $C)$ of passive samplers used to collect large-volume suspended-sediment samples at selected sites in Bexar County, Texas, 2007-09. 
An LVSS sample was transferred from the 25-L sample bottle into a custom 50-L churn so the sample could be stirred constantly during subsampling and filtration. The LVSS samples were filtered with a $0.45-\mu \mathrm{m}$ Teflon membrane to separate the sediment from the water. To enable water to readily pass through the filters, the Teflon membranes were sprayed with methanol before placing them on the filter holders. About two-thirds of the sample was filtered for organic compound analyses with a stainless-steel filter holder. The remaining onethird of the sample was filtered for analysis of major and trace elements with an acrylic filter holder. Duplicate samples of unfiltered water were pumped from the churned sample during filtration for SSC analysis. After filtration, the sediment was gently scraped from the Teflon membranes and transferred into sample jars. Samples for organic analyses were placed into pre-cleaned glass jars and shipped on ice to the NWQL for analysis. Samples for inorganic analyses were placed into polypropylene jars, freeze-dried, and pulverized before sending to the analytical laboratory. Both jars of the streambedsediment sample collected from the Martinez 1518 site on August 11, 2009, for the analysis of organic compounds broke during shipment to the laboratory. SSC samples inadvertently were not obtained from the LVSS samples collected from the Leon 35 site on May 16, 2009, and from the SAR Elmendorf site on March 12, 2009.

The LVSS samples were not sieved. For 18 of the 21 LVSS samples analyzed for grain size, more than 90 percent of particles were finer than $63 \mu \mathrm{m}$ (appendix 1.4).

\section{Analytical Methods}

Streambed-sediment samples were analyzed for major and trace elements and organic compounds. Organic compounds included halogenated organic compounds (chlordane, dieldrin, DDT, DDD [common name for dichlorodiphenyldichloroethane], and DDE [common name for dichlorodiphenyldichloroethylene], PCBs, and brominated flame retardants), SVOCs, and PAHs.

LVSS samples were analyzed for the same constituents as streambed-sediment samples; SSC also was determined for most LVSS samples. The USGS Sediment Laboratory at the Louisiana Water Science Center, Baton Rouge office, analyzed the LVSS samples for SSC by using the filtration method described by Guy (1969).

Freeze-dried sediment samples were analyzed for major and trace elements by the USGS Mineral Resources Program Analytical Laboratories in Lakewood, Colo. Total and inorganic carbon were determined by using methods described by Taggart (2002). Total carbon was analyzed by combustion with an automated carbon analyzer; inorganic carbon was determined as carbon dioxide by coulometric titration. Organic carbon was computed as the difference between the concentrations of total and inorganic carbon. Samples for major and trace element analyses were digested completely by using a mixture of hydrochloric, nitric, perchloric, and hydrofluoric acids and analyzed by inductively coupled plasma-mass spectrometry (ICP-MS) (Briggs and Meier, 2002). Concentrations of mercury were determined by continuous flow-cold vapor-atomic fluorescence spectrometry (CVAFS) (Hageman, 2007).

The sediment samples were analyzed for SVOCs and PAHs by gas chromatography/mass spectrometry (GC/MS) (Zaugg and others, 2006) at the NWQL. Surrogate compounds were added to the sample prior to extraction to monitor laboratory preparation, matrix effects, and method performance. The samples were extracted twice by using the ASE 200 accelerated solvent extraction system (Dionex, Sunnyvale, Calif.) at a pressure of 13,800 kilopascals with a water/isopropyl alcohol mixture (50:50, volume-to-volume ratio) at 120 degrees Celsius $\left({ }^{\circ} \mathrm{C}\right)$ and then a water/isopropyl alcohol mixture (20:80, volume-to-volume ratio) at $200{ }^{\circ} \mathrm{C}$ for 40 minutes. The constituents of interest were isolated from the extract by using disposable solid-phase extraction (SPE) cartridges containing divinylbenzene-vinylpyrrolidone copolymer resin. The SPE cartridge was dried partially with nitrogen gas, and sorbed compounds were eluted with a dichloromethane/diethyl ether mixture (80:20, volume-to-volume ratio) and passed through a second SPE cartridge, either a sodium sulfate or Florisil SPE cartridge, to dry and further "clean up" the extract by removing unwanted impurities. The concentrated extract was solvent exchanged into ethyl acetate, the solvent volume reduced, internal standard compounds added, and then analyzed by capillary-column GC/MS on an Agilent Technologies Model 5973, with the MS operated in the electron impact, full scan mode (Zaugg and others, 2006).

The samples were analyzed for halogenated organic compounds at the NWQL by using a custom analytical method. Custom methods have not been completely evaluated with USGS guidelines for developing official laboratory methods (U.S. Geological Survey, 2004), thus the official method prove-out has not been completed at the time of sample analyses. The samples were extracted by using the ASE 200 accelerated solvent extraction system as described previously for the PAHs. The extracts were analyzed by capillary-column GC/MS on an Agilent Technologies Model 5975, with the MS operated in the electron capture negative ion (ECNI) mode using ammonia as the reactant gas. The halogenated organic compounds were identified by selected ion monitoring (SIM) using the ions of interest (Mark Burkhardt and Steven Zaugg, U.S. Geological Survey, written commun., 2007).

\section{Quality Control}

Quality control for major and trace elements consisted of analyzing one or more laboratory blank samples, standard reference materials (SRMs), and duplicate or replicate samples submitted with each set of environmental samples (appendix 2.1). The samples collected during 2007-09 were analyzed for major and trace elements in 11 different sets. A lower reporting limit described by Taggart (2002, p. viii) as greater than or equal to "five times the standard deviation determined from the method blank" was used for major and trace elements. 
Major and trace element concentrations less than the respective lower reporting limits are hereinafter referred to as nondetections or nondetected concentrations, and concentrations equal to or greater than the respective lower reporting limits are hereinafter referred to as detections or detected concentrations. One or more major or trace elements were detected in 3.5 percent of the blank samples; beryllium, lithium, and scandium were the most frequently detected. The laboratory analyzed SRMs, compared the values to published or standard results, and computed the percent recovery. The SRM results are used to assess bias for each analysis. It is difficult to assess the results of the SRMs because the acceptable uncertainty of concentrations varies between elements and SRMs. For example, the National Institute of Standards and Technology (NIST) SRMs 8704 and 2709 were analyzed with the samples collected in Bexar County during 2007-09 (appendix 2.1). The true concentration of lead in SRM 8704 is 150 micrograms per gram $(\mu \mathrm{g} / \mathrm{g})$ plus or minus 11 percent ( 1 standard deviation), whereas the true concentration of cadmium in SRM 2709 is $18.9 \mu \mathrm{g} / \mathrm{g}$ plus or minus 2.6 percent (1 standard deviation) (National Institute of Standards and Technology, 2008 and 2003, respectively). The certificates of analysis could not be obtained for all SRMs analyzed with the Bexar County samples collected during 2007-09; therefore, no conclusions are made about the overall acceptability of the results of the SRMs.

Quality control for organic analyses consisted of analyzing a laboratory blank sample, a spike sample, and a duplicate sample, as well as monitoring recovery of surrogate compounds with each set of environmental samples (Mark Burkhardt and Steven Zaugg, U.S. Geological Survey, written commun., 2007). The samples collected during 2007-09 were analyzed for halogenated organic compounds in 12 different sets (appendix 2.2). Halogenated organic compound concentrations less than the respective interim reporting levels (IRLs) are hereinafter referred to as nondetections or nondetected concentrations, and concentrations equal to or greater than the respective IRLs are referred to as detections or detected concentrations. The IRL is a temporary reporting level used for new or custom schedules when long-term method detection level data are unavailable and an LRL has not yet been established (William Foreman, U.S. Geological Survey, written commun., 2011). In 7 percent of the blank samples, one or more halogenated organic compounds were detected; triclosan and polybrominated diphenyl ethers (PBDEs) 47, 99, and 100 were the most frequently detected compounds. Detections in the triclosan, PBDE 47, PBDE 99, and PBDE 100 blanks were at concentrations greater than the respective IRLs 85 percent of the time. Detections of halogenated organic compounds in blank samples, particularly at concentrations equal to or greater than the IRLs, indicate the possibility of false positives during environmental sample analyses. Whenever a halogenated organic compound was detected and identified in the blank, the quantification of that same compound in the environmental sample was qualified as estimated with the "E" remark code.
Spike results provide information about method performance and are used to assess potential bias of environmental sample results (Pirkey and Glodt, 1998). The average halogenated organic compound spike recoveries, by compound, ranged from 54.2 percent for PCB 52 to 145.2 percent for PBDE 47 (appendix 2.2). The overall average spike recovery for the halogenated organic compounds was 80.7 percent. The NWQL established acceptable spike recovery ranges after the analysis of some of the samples collected during 2007-09; those acceptable ranges were reported with the last three sets of samples and applied to all spike results. Spike recoveries were within acceptable ranges for 98 percent of the spike results. Spike recoveries were low in set one for PCB 206 and pentabromotoluene; in set two for fipronil sulfide; in set four for pendimethalin; in set 200926406 for triclosan and pentabromotoluene; and in set 201002204 for triclosan, desulfinyl fipronil, fipronil, fipronil sulfide, and pentabromotoluene (appendix 2.2). Spike recoveries were high in set one for cyhalothrin, $p, p^{\prime}$-DDD, and PBDE 47; in set two for PBDE 47; in set ten for PCB 49; and in sets 200926405 and 200926406 for fipronil (appendix 2.2). Concentrations of the halogenated organic compounds in those sets with low or high spike recoveries were considered unreliable and the environmental sample results were qualified as estimated with an "E" remark code when detected concentrations were reported (appendix 1.2).

Surrogates are used to monitor the recovery efficiency of the analytical processes. Surrogate recoveries are not used to correct concentrations because the surrogates do not chemically mimic all compounds in the laboratory method (Noriega and others, 2003). The average surrogate recoveries of all environmental and quality control samples analyzed for halogenated organic compounds were 61.1, 67.4, and 79.4 percent for dibromoocta-fluorobiphenyl, PCB $202-{ }^{13} C_{12}$, and DDT- $d_{8}$, respectively. Surrogate recovery control limits are established similarly to spike recoveries. Surrogate recoveries were within control limits of 20 to 104 percent for dibromooctafluorobiphenyl, 38 to 110 percent for PCB $202-{ }^{13} C_{12}$, and 39 to 129 percent for DDT- $d_{8}$ for 88 percent of the sample analyses. The NWQL checks and adjusts the method when surrogate recoveries are outside control limits (Mark Burkhardt and Steven Zaugg, U.S. Geological Survey, written commun., 2007).

The samples were analyzed for SVOCs and PAHs in 11 sets (appendix 2.3). Compound concentrations less than the respective IRLs are hereinafter referred to as nondetections or nondetected concentrations, and concentrations equal to or greater than the respective IRLs are referred to as detections or detected concentrations. Detections were reported in 28 percent of the blank results, with most detections for 2-ethylhexyl phthalate, diethyl phthalate, fluoranthene, naphthalene, phenanthrene, and pyrene. Most of the blank detections (97 percent) were less than the IRLs for the respective compounds except for 2-ethylhexyl phthalate, which was detected in the blanks at concentrations greater than the IRLs in 64 percent of the sample sets. Diethyl phthalate was detected in 27 percent of the set blanks at concentrations greater than the IRLs. 
Concentrations of fluoranthene, pyrene, and benzo(g,h,i) perylene were greater than the IRLs in the blank sample for set 200901505. Whenever an SVOC or PAH was detected and identified in the blank, the quantification of that same compound in the environmental sample was qualified as estimated with an "E" remark code.

The average spike recoveries by compound ranged from 54.9 percent for pentachloronitrobenzene to 95.8 percent for benzo(b)fluoranthene. The overall average spike recovery for the SVOCs and PAHs was 81.2 percent. The NWQL establishes annually acceptable spike recovery ranges on the basis of historical spike analyses. Spike recoveries were within acceptable ranges for 98 percent of the spike results. Spike recoveries of hexachlorobenzene and pentachloroanisol in set 200926502 were slightly less than the acceptable recovery ranges, and naphthalene in set 200826801 and benzo(e)pyrene and benzo(k)fluoranthene in set 200915405 were slightly greater than the acceptable recovery ranges (appendix 2.3). Spike recoveries of 1,2,4-trichlorobenzene in sets 200915405 and 200826801 were much greater than the acceptable range of 19 to 89 percent and the concentrations of the compound in the two sets are considered unreliable (positive bias). Concentrations of SVOCs or PAHs in those sets with low or high spike recoveries were considered unreliable and the environmental sample results were qualified as estimated with an "E" remark code when detected concentrations were reported (appendix 1.3).

The average surrogate recoveries of all environmental and quality control samples analyzed for SVOCs and PAHs were 63.6, 37.3, and 73.3 percent for 2-fluorobiphenyl, nitrobenzene- $d_{5}$, and $p$-terphenyl- $d_{14}$, respectively. Surrogate recoveries were within control limits of 0 to 151 percent for 2-fluorobiphenyl, 4 to 157 percent for nitrobenzene- $d_{5}$, and 37 to 120 percent for $p$-terphenyl- $d_{14}$, for 93 percent of the sample analyses. The NWQL checks and adjusts the method when surrogate recoveries are outside the control limits (Zaugg and others, 2006).

Two types of duplicate or replicate samples were usedlaboratory replicates in which the laboratory runs the analysis two or more times, and environmental duplicates in which two or more separate jars of sediment collected concurrently or sequentially are submitted to the laboratory for separate analyses. Replicates provide information about variability in the analytical process, but their results can be affected by sample heterogeneity, particularly when sediments are the sample media (Pirkey and Glodt, 1998). The relative percent difference (RPD) was computed between each pair of duplicate analyses to provide a measure of precision by using the equation

$$
\mathrm{RPD}=\left|\mathrm{C}_{1}-\mathrm{C}_{2}\right| /\left(\left(\mathrm{C}_{1}+\mathrm{C}_{2}\right) / 2\right) \times 100,
$$

where

$\mathrm{C}_{1}$ is the constituent concentration, in micrograms per gram or micrograms per kilogram, from the environmental sample; and
$\mathrm{C}_{2}$ is the constituent concentration, in micrograms per gram or micrograms per kilogram, from the duplicate sample.

Eleven environmental samples were analyzed in duplicate or replicate for major and trace elements (appendix 2.1). The overall average RPD for the major and trace element duplicates was 5.1 percent. Nine laboratory duplicate and two environmental duplicate samples were analyzed for halogenated organic compounds (appendix 2.2). The overall average RPD for the halogenated organic compound duplicates was 45.4 percent. Two environmental duplicate samples were analyzed for SVOCs and PAHs (appendix 2.3) with an overall average RPD of 40.6 percent. The RPDs of duplicate organic analyses are larger than in previous USGS sediment studies using the NWQL and similar analyses (for example, Van Metre and others, 2003; Van Metre and others, 2004).

Numerous factors affect the analytical results of organic compounds reported by the NWQL. The IRLs for organic compounds increase as the sediment mass available for analysis decreases. This results in higher IRLs for small-mass samples such as the LVSS samples. The NWQL uses an "E" remark code to signify that the concentration is an estimated value for one or more possible reasons. For most samples, at least one constituent was qualified as estimated with an "E" remark code. When an organic compound is detected in the blank sample, an "E" remark code is assigned to the results of that same compound in the environmental sample. All alkylated PAH results are assigned an "E" remark code because no calibration standards exist for these compounds. Some organic compounds are assigned an "E" remark code either because of matrix interference or because the compounds are highly variable and the precision or accuracy of the analytical method is questionable. Concentrations that are extrapolated because they are less than the lowest calibration standard, method range, or instrument range are also assigned an "E" remark code (Childress and others, 1999). All major and trace element, SVOC, and PAH data from discrete environmental samples collected by the USGS, including results for qualitycontrol samples, were published in the USGS National Water Information System (NWIS) (U.S. Geological Survey, 2011).

\section{Assessment of Selected Contaminants in Streambed- and Suspended- Sediment Samples}

Selected constituents in streambed-sediment samples and suspended-sediment (LVSS) samples collected at sites in the watersheds of eight major streams in Bexar County during 2007-09 were assessed by using a variety of methods. The concentrations of trace elements and organic compounds measured in the streambed-sediment and LVSS samples are described and concentrations in streambed-sediment samples and LVSS samples are compared. Contaminant concentrations 
also are compared to sediment-quality guidelines (SQGs) and to concentrations in samples collected previously at the same locations.

Statistical analyses are used to describe similarities or differences in the sediment concentrations between watersheds and to describe the relation between concentrations and land use. Detailed land-use data were only available for Bexar County, resulting in less than 100-percent land-use coverage in the study area for the Medio Creek, Medina River, and Elm Creek contributing areas (figs. 1-2; table 2). Lastly, the sources of PCBs and PAHs are investigated by using source indicator ratios, profiles, and a chemical mass balance model (PAHs only).

Total concentrations of chlordane, DDT, PCBs, and PAHs were estimated by by using the Kaplan-Meier method to determine the mean concentration of a group of compounds while accounting for censored data points and then multiplying the mean by the number of compounds in the group to produce an estimate of the total (Helsel, 2009). Estimated concentrations (assigned an "E" remark code) were used at their concentration values and no values were substituted for the nondetected concentrations in the computation of means. In groups with a single detection, an estimate of the total concentration was not possible with the Kaplan-Meier method and the total concentration was listed as "not detected."

\section{Occurrence and Distribution of Sediment- Associated Constituents}

Comparisons of sediment-associated constituents between sites can be affected by variability in sediment properties such as grain size and organic carbon content. Trace element concentrations correlate positively with the less-than$125-\mu \mathrm{m}$ (very fine sand and finer) and less-than-63-mm (silt and finer) sediment fractions (Horowitz and Elrick, 1987). The streambed-sediment samples were sieved and the fraction finer than $63 \mu \mathrm{m}$ was analyzed for major and trace elements. The consistent grain size of LVSS samples also precluded the need to normalize trace-element concentrations for these samples.

Hydrophobic organic compounds are known to sorb to the organic matter in sediments (for example, Chiou and others, 1979; Karickhoff and others, 1979). A Kruskal-Wallis analysis of variance test (Iman and Conover, 1983) was used to determine that the amounts of organic carbon in each watershed have equivalent distributions; the attained significance level (p-value) was .062. Because the percent organic carbon did not vary significantly (p-value less than .05 statistically significant) among analyses obtained from sites in the eight watersheds, the concentrations of organic compounds were not normalized for organic carbon.

The average SSC was computed for each LVSS sample by using the SSC measured in the duplicate samples collected during churning and filtration (table 4). Because SSC samples were inadvertently not obtained from the LVSS sample at the Leon 35 site on May 16, 2009, and the SAR Elmendorf site on March 12, 2009, those SSCs are estimates computed as the average of the SSCs measured in other samples collected from the same sites. SSC for all sites ranged from relatively low values in samples from the Martinez St. Hedwig and Leon 35 sites (360 and 362 milligrams per liter [mg/L], respectively) to relatively high values in samples from the Medina and SAR 410 sites (2,296 and 2,744 mg/L, respectively). The SSC in the samples from the Salado Southton site was about 1 order of magnitude less in 2009 (311 mg/L) compared to $2008(1,988 \mathrm{mg} / \mathrm{L})$.

The mass of contaminant per unit volume of stormwater was compared among sites. The mass of contaminant per unit volume of stormwater (micrograms or nanograms per liter) was calculated by dividing the concentration of contaminant by the average SSC of each suspended-sediment sample. Compared to concentrations measured at others sites in the study area, relatively high contaminant concentrations and SSCs were measured in LVSS samples from the SAR 410 site. Some of the highest contaminant concentrations (except for cadmium, $p, p^{\prime}$-DDE, and a brominated flame retardant, dechlorane plus) and some of the highest SSCs in the study area were measured in samples collected from the SAR 410 site (table 4); these high LVSS concentrations are consistent with the streambed-sediment contaminant concentrations at the site. Conversely, despite high contaminant concentrations in the streambed-sediment and LVSS samples collected from the Leon 35 site, the mass of contaminant per liter of stormwater at this site is not particularly large because of the moderate SSCs in the stormwater samples. Samples collected from the Martinez St. Hedwig site typically had the lowest values of mass of contaminant per liter of stormwater, which is a result of both low LVSS contaminant concentrations and low SSCs.

Trace elements may be derived from geologic materials and anthropogenic sources (Garbarino and others, 1995). Arsenic, lead, mercury, and cadmium are among the top 10 (table 1) of the "CERCLA Priority List of Hazardous Substances" (Agency for Toxic Substances and Disease Registry, 2007a), all four priority trace elements were detected in all samples collected at all sites.

Arsenic was used as an agricultural insecticide until the 1950s and as a wood preservative until 2003. Arsenic also occurs naturally in groundwater in small amounts (generally 3 micrograms per liter $[\mu \mathrm{g} / \mathrm{L}]$ or less) in central Texas (Ryker, 2001) and groundwater contributes to streamflow in the study area (Ockerman and McNamara, 2003). The greatest concentrations of arsenic were in streambed-sediment samples collected from the following sites: Chupaderas $(22.2 \mu \mathrm{g} / \mathrm{g})$, Leon $90(12.8 \mu \mathrm{g} / \mathrm{g})$, and Leon Morey $(12.2 \mu \mathrm{g} / \mathrm{g}$ ) (appendix 1.1). The Chupaderas Creek watershed is the smallest of the watersheds for the eight major streams in Bexar County. The contributing area of the Chupaderas site has one of the lowest population densities (61 people per square kilometer) among all contributing areas composing the eight major watersheds in Bexar County and is 83.6 percent undeveloped land (table 2). Abandoned municipal solid waste landfill sites are the most common PSOC in the Chupaderas Creek watershed 
Table 4. Suspended-sediment concentration and mass of contaminant per unit volume of stormwater for large-volume suspendedsediment samples collected by passive samplers at selected sites in Bexar County, Texas, 2008-09.

[SSC, suspended-sediment concentration; mg/L, milligrams per liter; $\mu \mathrm{g} / \mathrm{L}$, micrograms per liter; E, estimated (SSC sample inadvertently not obtained from large-volume suspended-sediment sample; therefore, SSC estimated from average of SSCs measured in other samples collected at site); ng/L, nanograms per liter; PCBs, polychlorinated biphenyls; PAHs, polycyclic aromatic hydrocarbons; PBDE, polybrominated diphenyl ether; ND, not detected]

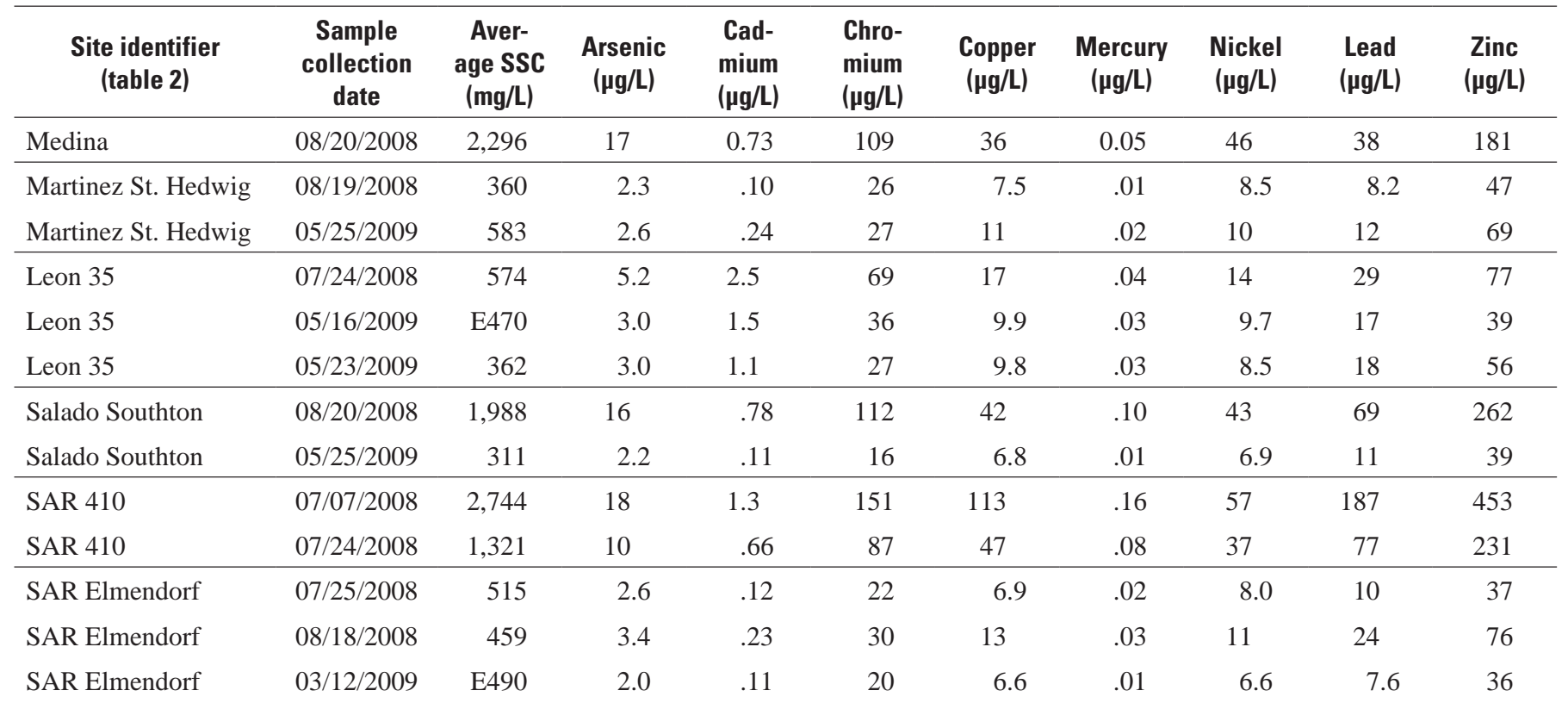

\begin{tabular}{|c|c|c|c|c|c|c|c|c|c|c|c|c|}
\hline $\begin{array}{l}\text { Site identifier } \\
\text { (table 2) }\end{array}$ & $\begin{array}{c}\text { Sample } \\
\text { collection } \\
\text { date }\end{array}$ & $\begin{array}{l}\text { Aver- } \\
\text { age } \\
\text { SSC } \\
\text { (mg/L) }\end{array}$ & $\begin{array}{c}\text { Diel- } \\
\text { drin } \\
\text { (ng/L) }\end{array}$ & $\begin{array}{l}\text { Total } \\
\text { chlor- } \\
\text { dane } \\
\text { (ng/L) }\end{array}$ & $\begin{array}{c}p, p^{\prime}- \\
\text { DDD } \\
\text { (ng/L) }\end{array}$ & $\begin{array}{c}p, p^{\prime}- \\
\text { DDE } \\
\text { (ng/L) }\end{array}$ & $\begin{array}{l}\text { Total } \\
\text { PCBs }^{2} \\
\text { (ng/L) }\end{array}$ & $\begin{array}{l}\text { Total } \\
\text { PAHs }^{3} \\
\text { (ng/L) }\end{array}$ & $\begin{array}{c}\text { PBDE } \\
153 \\
\text { (ng/L) }\end{array}$ & $\begin{array}{c}\text { PBDE } \\
154 \\
\text { (ng/L) }\end{array}$ & $\begin{array}{c}\text { Dechlor- } \\
\text { ane plus } \\
\text { (ng/L) }\end{array}$ & $\begin{array}{c}\text { 1,2-bis } \\
\text { (2,4,6-tri- } \\
\text { bromo- } \\
\text { phenoxy)- } \\
\text { ethane } \\
\text { (ng/L) }\end{array}$ \\
\hline Medina & 08/20/2008 & 2,296 & 0.11 & 0.56 & ND & ND & 2.8 & ND & 0.73 & 0.52 & 0.21 & 0.09 \\
\hline Martinez St. Hedwig & 05/25/2009 & 583 & ND & ND & ND & ND & ND & ND & ND & ND & ND & ND \\
\hline Leon 35 & 07/24/2008 & 574 & .18 & 2.2 & 4.0 & ND & 15 & 92 & .24 & .20 & 2.2 & .18 \\
\hline Leon 35 & 05/16/2009 & $\mathrm{E} 470$ & ND & ND & ND & ND & 3.9 & ND & ND & ND & .33 & ND \\
\hline Leon 35 & 05/23/2009 & 362 & ND & .94 & ND & ND & 4.7 & 724 & .12 & .09 & .40 & .16 \\
\hline SAR 410 & 07/24/2008 & 1,321 & 1.1 & 8.9 & 8.2 & ND & 13.2 & 4,756 & 1.0 & .98 & 1.7 & .41 \\
\hline SAR Elmendorf & $07 / 25 / 2008$ & 515 & .04 & .46 & .72 & ND & 1.6 & ND & .21 & .17 & .25 & .10 \\
\hline SAR Elmendorf & 08/18/2008 & 459 & .15 & 2.0 & ND & 2.8 & 5.5 & ND & .50 & .35 & .55 & .25 \\
\hline SAR Elmendorf & 03/12/2009 & E490 & ND & .45 & ND & ND & 1.3 & ND & ND & ND & .24 & ND \\
\hline \multicolumn{13}{|c|}{${ }^{1}$ Total chlordane is sum of cis-chlordane, trans-chlordane, cis-nonachlor, trans-nonachlor, and oxychlordane. } \\
\hline
\end{tabular}


(Texas Commission on Environmental Quality, 2009a; fig. 3). According to the Alamo Area Council of Governments (2002), two unauthorized landfills of unknown size and unknown dates of use were found near Chupaderas Creek; contaminants leaching from these landfills might be contributing to elevated arsenic concentrations in streambed sediment at the Chupaderas site.

Much of the lead in the environment comes from the burning of fossil fuels, mining, and manufacturing (Agency for Toxic Substances and Disease Registry, 2007b). The greatest lead concentrations, 69.3 and $65.0 \mu \mathrm{g} / \mathrm{g}$, were measured in streambed-sediment samples collected from the Leon 35 and Leon Quintana sites, respectively. A lead concentration of $68.2 \mu \mathrm{g} / \mathrm{g}$ was measured in an LVSS sample collected from the SAR 410 site (appendix 1.1). The percentages of industrial and mining land use in the contributing areas for these three sites are larger than the median values for all contributing areas in the study area (table 2).

Mercury historically was used in thermometers and other scientific meters and in dental amalgams. Mercury is emitted to the atmosphere by oceans, volcanoes, coal-fired power plants, waste incineration, gold mining, and caustic soda, cement, and metal production (Pacyna and others, 2006). Mercury concentrations were greatest in streambed-sediment samples collected from the Leon Quintana site ( 0.09 and 0.08 $\mu \mathrm{g} / \mathrm{g}$ ), an LVSS sample collected from the SAR Elmendorf site $(0.07 \mu \mathrm{g} / \mathrm{g})$, and two LVSS samples collected from the Leon 35 site (both $0.07 \mu \mathrm{g} / \mathrm{g}$ ) (appendix 1.1). The percentages of industrial and mining land use in the contributing areas for these three sites are relatively large compared to the median values for all contributing areas in the study area (table 2).

Cadmium is used predominantly in nickel-cadmium batteries but also has minor uses for coating and electroplating, in pigments, as a polyvinylchloride (PVC) stabilizer, and as an alloy in a variety of other metals; until the 1980 s, cadmium was commonly used for coating metals to prevent corrosion and as a pigment (Llewellyn, 1994). The greatest concentrations of cadmium were in streambed-sediment samples collected from the Leon Quintana site (6.5 and $5.4 \mu \mathrm{g} / \mathrm{g})$, an LVSS sample collected from the Leon 35 site $(4.4 \mu \mathrm{g} / \mathrm{g})$, and a streambed-sediment sample collected from the Leon 35 site (4.1 $\mu \mathrm{g} / \mathrm{g}$ ) (appendix 1.1). As previously stated, the percentages of industrial and mining land use in the contributing areas for these two sites are larger than the median values for all contributing areas in the study area (table 2). In addition, activities that used or involved cadmium such as electroplating and disposal of scrap metals were known to occur in zones 1 and 2 at the former Kelly AFB (fig. 4), upstream from the two sampling sites (CH2M Hill, 2001).

Halogenated organic compounds that were measured in sediment samples include pesticides, PCBs, and brominated flame retardants. At least three or more halogenated organic compounds were detected in each sediment sample collected from the Bexar County sites during 2007-09 (appendix 1.2) and 66 percent of the halogenated organic compound concentrations measured were less than the respective IRLs (nondetections). Detection frequencies of halogenated organic compounds in all streambed-sediment and LVSS samples are shown in figure 7 by watershed. Chlordane was widely used as an insecticide in agriculture and residential applications and for termite control until being banned in the United States in the 1980s (Agency for Toxic Substances and Disease Registry, 1994). Chlordane is a mixture of numerous related compounds; samples collected during 2007-09 were analyzed for two isomers (cis-chlordane and trans-chlordane), two other components (cis-nonachlor and trans-nonachlor), and a metabolite (oxychlordane). For this report, total chlordane is defined as the sum of these five chlordane-related compounds. The chlordane compounds were the most frequently detected of the halogenated organic compounds (detected in 94 percent of samples) with one or more detections of chlordane compounds in every watershed (fig. 7). The highest concentrations of total chlordane were in a streambed-sediment sample collected from the Leon Lackland site (11 micrograms per kilogram $[\mu \mathrm{g} / \mathrm{kg}]$ ) and in an LVSS sample collected from the SAR 410 site $(6.7 \mu \mathrm{g} / \mathrm{kg})$ (appendix 1.2). Chlordane was commonly used as a termite pesticide, especially in the southern U.S. Because of its widespread historical use and extreme environmental persistence, chlordane is commonly found in the environment throughout most of the United States (Agency for Toxic Substances and Disease Registry, 1994).

DDT is a pesticide that was used widely in the United States in agriculture applications and for the control of disease-carrying insects (such as mosquitoes and malaria) until being banned in 1972 because of its persistence in the environment and toxicity to wildlife. The parent product, DDT, and its breakdown products, DDD and DDE, all have similar chemical and physical properties (Agency for Toxic Substances and Disease Registry, 2002). Each compound has three forms (for example, the three forms of DDT are $p, p^{\prime}-$ DDT, $o, p^{\prime}$-DDT, and $o, o^{\prime}$-DDT), but only the primary form $(p, p)$ was analyzed in the samples collected during 2007-09. The most frequently detected compound of the group was the breakdown product $p, p^{\prime}$-DDE. Concentrations of $p, p^{\prime}$-DDT, $p, p^{\prime}$-DDD, or $p, p^{\prime}$-DDE were not detected in samples from sites in the Medina River, Elm Creek, or Chupaderas Creek watersheds (fig. 7). The DDT compounds were detected most frequently in the Leon Creek and San Antonio River watersheds. The highest concentrations were in streambed-sediment samples collected from the Leon Lackland and Leon Military sites (appendix 1.2), adjacent to zones 1 and 2 of the former Kelly AFB (fig. 4), where CH2M Hill (2001) documented the presence of pesticide disposal sites. Sediments with relatively higher concentrations of DDT than DDE are likely the result of a recent introduction of parent DDT into the environment (Hitch and Day, 1992). A DDE/DDT ratio greater than 1 is indicative of long-term degradation of DDT (Lindsey and others, 1998). Four samples had detections of DDE and DDT - three from the Leon Lackland site (DDE/DDT ratios $0.37,1.3$, and 0.19) and one from the Leon Military site (DDE/ DDT ratio 4.3). The ratios less than 1 at the Leon Lackland site imply recent introduction of parent DDT at or upstream 
from the sampling site, possibly by disturbance of buried waste or by recent use.

Dieldrin, an agricultural pesticide and termiticide widely used from the 1950s to 1970 s, was detected occasionally in all eight major watersheds except the Chupaderas Creek watershed (fig. 7). Dieldrin was detected in 50 percent of all samples collected during 2007-09 but not detected in any samples from the Martinez 1518, Chupaderas, and Leon Morey sites. Dieldrin concentrations were highest in a streambed-sediment sample from the Leon Rodriguez site $(1.1 \mu \mathrm{g} / \mathrm{kg})$ and an LVSS sample from the SAR 410 site $(0.84 \mu \mathrm{g} / \mathrm{kg})$ (appendix 1.2). Dieldrin is commonly found in the environment because of its persistence and widespread use as a termiticide.

Fipronil is currently (2010) a widely used broad spectrum insecticide. The compound or its metabolites, desulfinyl fipronil and fipronil sulfide, were detected frequently in samples from all sites except from the Elm Creek and Chupaderas Creek watersheds (fig. 7).

PCBs were first synthesized in the early 1930s and have had widespread industrial uses, primarily as plasticizers, hydraulic lubricants, and dielectric fluids in electrical capacitors (Smith and others, 1988). Adverse human health effects and cancer in animals have been associated with exposure to PCBs. PCBs were no longer manufactured in the United States beginning in 1977 and were banned in 1979 (Agency for Toxic Substances and Disease Registry, 2000). PCBs include as many as 209 theoretically possible chlorinated compounds, called congeners, with various numbers and positions of chlorine atoms attached to the biphenyl structure. Each congener has been assigned a congener number that generally increases with increasing chlorination of the biphenyl structure (Ballschmiter and Zell, 1980). The NWQL quantified 18 common PCB congeners for the sediment samples collected during 2007-09. Total PCBs, representing the sum of the 18 reported congeners (appendix 1.2), were computed by using the Kaplan-Meier method (Helsel, 2009).

PCBs sorb to organic matter and particulates and are commonly detected in sediments from urban water bodies (Van Metre and others, 1997; Wong and others, 2000). The larger congeners tend to sorb strongly to solids such as sediments, whereas the smaller congeners are more likely to volatilize (Eisenreich, Capel, and Looney, 1983; Eisenreich and others, 1992; Pearson and others, 1996). One or more PCB congeners were detected in 90 percent of streambed-sediment and LVSS samples collected from all sites (appendix 1.2). Samples with the fewest detections of PCBs were collected from the Martinez St. Hedwig and Chupaderas sites, whereas samples with the most detections were collected from the Leon Lackland, Leon 35, and SAR 410 sites.

In most watersheds, larger congeners (PCBs 118 to 206) were detected more frequently than the smaller congeners (PCBs 49 to 110). The highest total PCB concentrations were in a streambed-sediment sample collected from the Leon Lackland site $(77 \mu \mathrm{g} / \mathrm{kg})$ and an LVSS sample collected from the Leon 35 site $(26 \mu \mathrm{g} / \mathrm{kg})$. The percentage of industrial land use in the contributing area for the Leon Lackland site is near the median value for all contributing areas in the study area; in addition CH2M Hill (2001) documented the disposal of waste lubricants in zone 1 of the former Kelly AFB (fig. 4). The percentage of industrial land use in the contributing area for the Leon 35 site is larger than the median value for all contributing areas in the study area, which might explain the higher PCB concentrations in samples collected from these sites.

Brominated flame retardants are added to plastics and textiles polymers to increase the fire resistance of products such as electronics, clothing, and furniture (U.S. Environmental Protection Agency, 2010c). Global annual production of brominated flame retardants is in the hundreds of thousands tons per year (Alaee and others, 2003). Some brominated flame retardants have been in use since the 1960s, and the global demand for the compounds grew substantially during the 1990s and 2000s. One group of brominated flame retardants, PBDEs, includes 209 possible compounds; these compounds are structurally similar to PCBs and are also referred to as congeners (Agency for Toxic Substances and Disease Registry, 2004). PBDEs are ubiquitous in the environment and have been detected in house dust, sediments, human blood serum, and biota (Zegers and others, 2000; Sjödin, Patterson, and Bergman, 2001; Norstrom and others, 2002; Sjödin and others, 2008). There is some evidence that the compounds may have toxic effects on humans and animals (U.S. Environmental Protection Agency, 2010c). The European Union (European Parliament and European Council, 2003) and the U.S. Environmental Protection Agency (2006) have banned the manufacture and use of some PBDEs.

The sediment samples collected during 2007-09 were analyzed for PBDEs and three other brominated flame retardants: dechlorane plus, pentabromotoluene, and 1,2-bis(2,4,6tribromophenoxy)ethane (Firemaster 680). Brominated flame retardants were not detected in the samples collected from the Elm Creek or Chupaderas Creek watersheds (fig. 7). The most frequent detections occurred in samples collected from the Medio Creek, Leon Creek, and San Antonio River watersheds. The highest concentrations of the four most frequently detected brominated flame retardants, PBDEs 100, 153, 154, and dechlorane plus, were in samples collected from the Medio 90, Leon 35, Salado Southton, SAR 410, and SAR Elmendorf sites (fig. 8). This is one of the few instances when some of the highest concentrations of a constituent were measured in a sediment sample collected from the Medio 90 site and could be related to the high percentage of plastic manufacturing and sales in the contributing areas of Medio Creek watershed (see last paragraph in "Description of Study Area" section). Few reports describing the deposition of individual PBDEs to sediments in the United States have been published; the majority of reports describe total PBDEs or relative concentrations (not concentrations of individual congeners), PBDEs in animals, PBDEs sampled with semipermeable devices, or PBDEs in other media such as air or dust. Dodder and others (2002) reported PBDE congener concentrations in bottom sediments from Hadley Lake in northwest Indiana, south of the Great Lakes region, where PBDEs are of concern. 


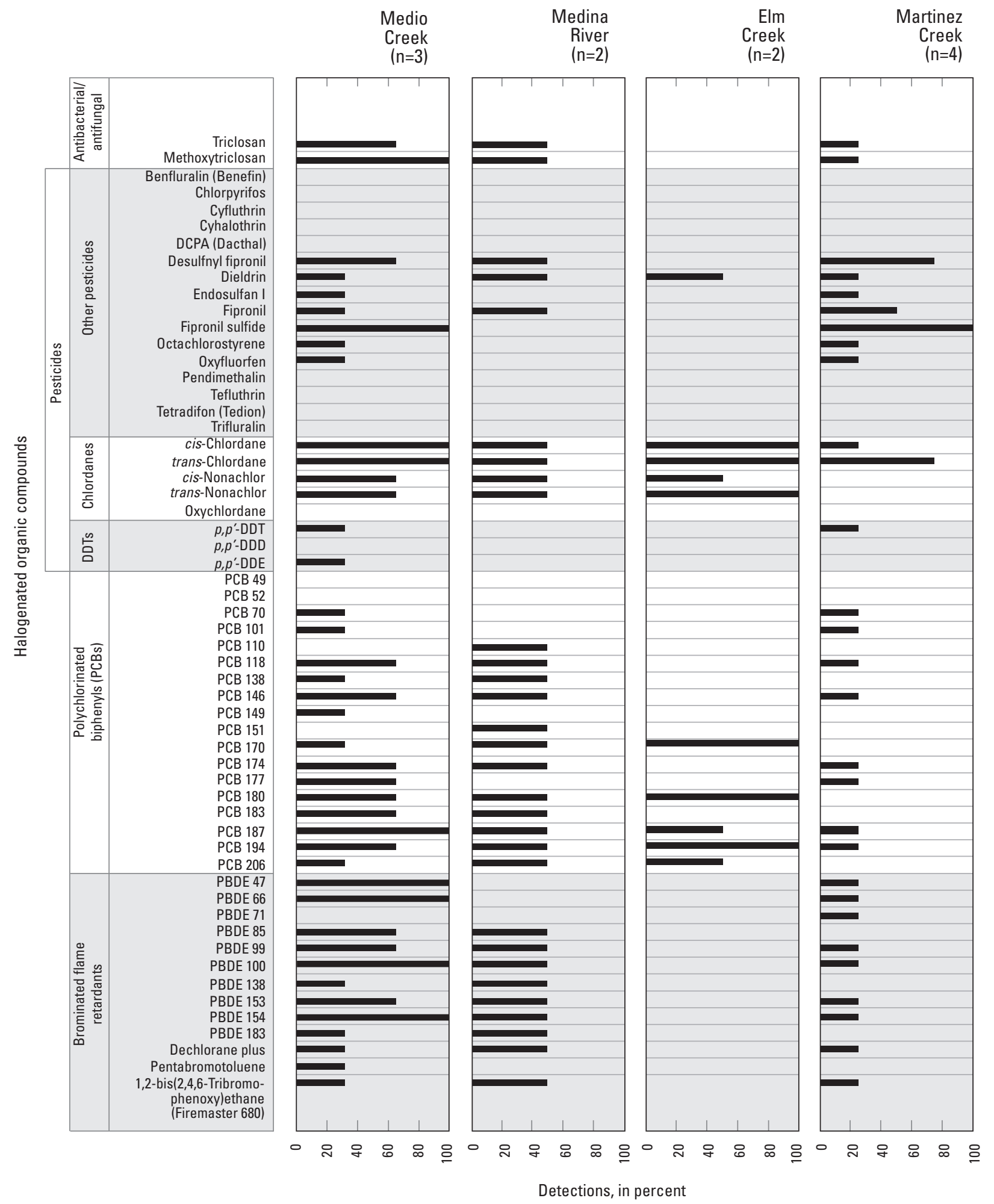

[n, number of samples; DCPA, dimethyltetrachloro terephthalate; DDT, dichlorodiphenyltrichloroethane; DDD, dichlorodiphenyldichloroethane; $\mathrm{DDE}$, dichlorodiphenyldichloroethylene; $\mathrm{PCB}$, polychlorinated biphenyl; PBDE, polybrominated diphenyl ether]

Figure 7. Detection frequencies of halogenated organic compounds in streambed-sediment and suspended-sediment samples, by watershed, in Bexar County, Texas, 2007-09. 


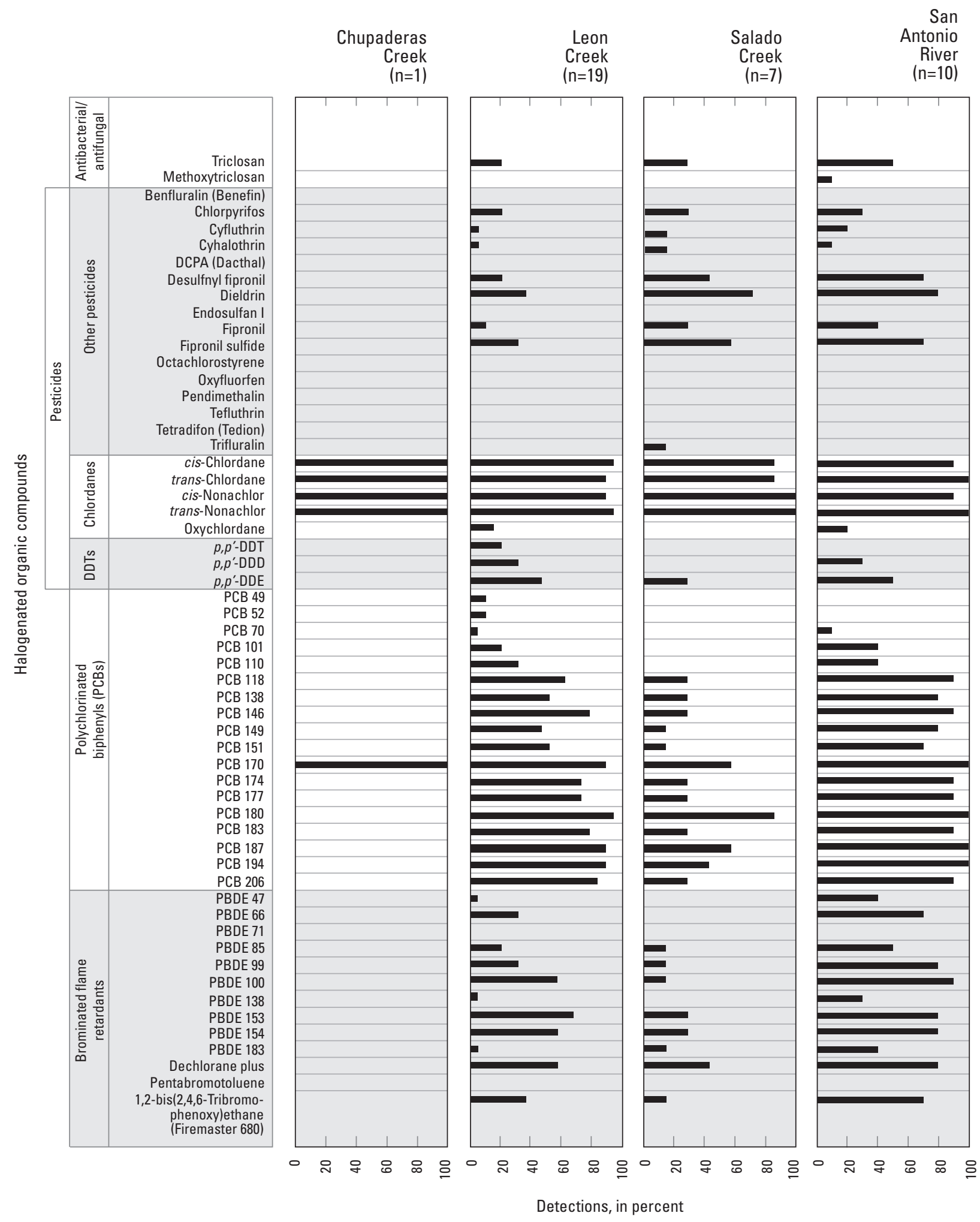

[n, number of samples; DCPA, dimethyltetrachloro terephthalate; DDT, dichlorodiphenyltrichloroethane; DDD, dichlorodiphenyldichloroethane; $\mathrm{DDE}$, dichlorodiphenyldichloroethylene; PCB, polychlorinated biphenyl; PBDE, polybrominated diphenyl ether]

Figure 7.-Continued. 

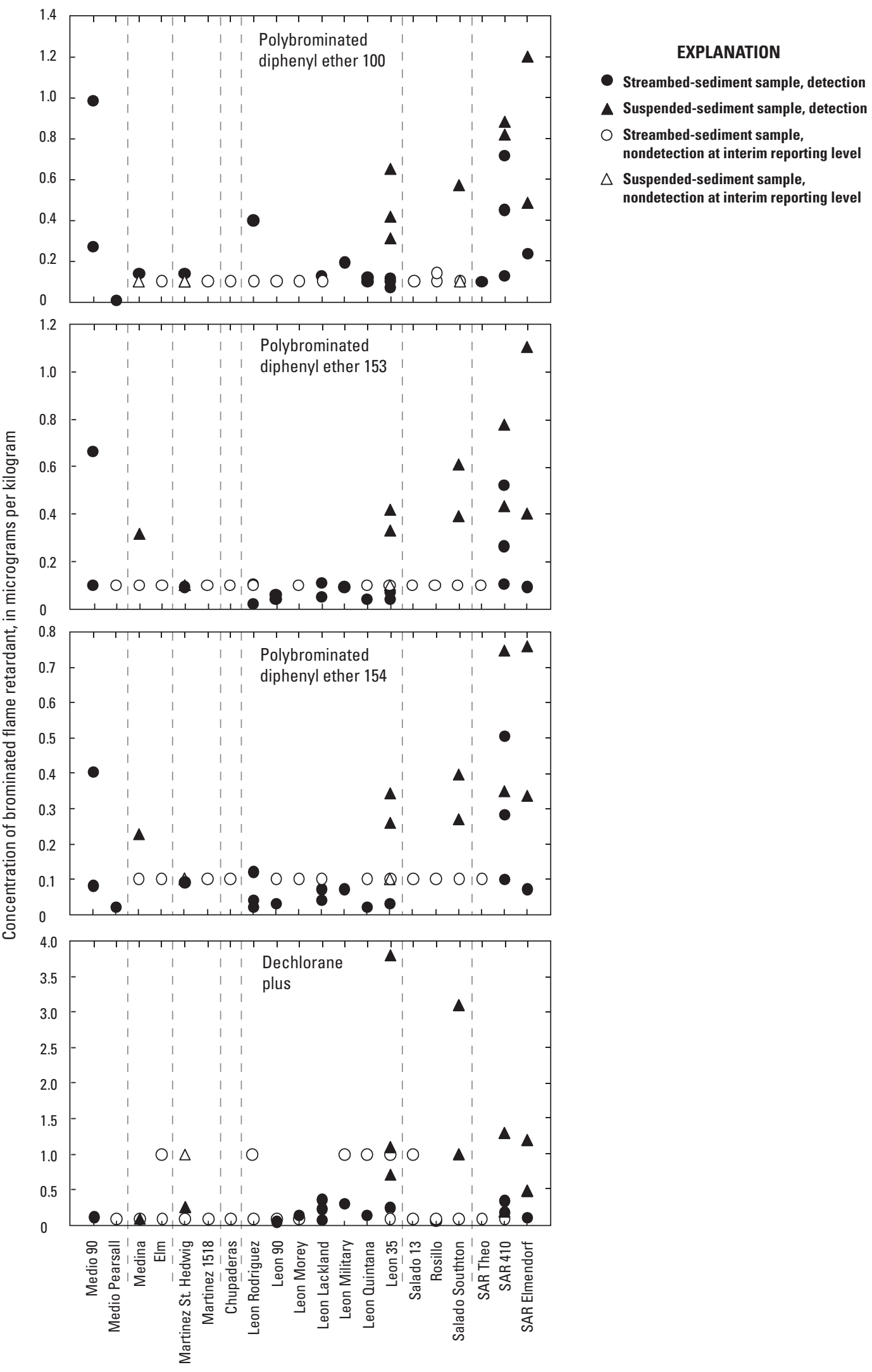

nondetection at interim reporting level

Site identifier (table 2)

Figure 8. Concentrations of the four most frequently detected brominated flame retardants in streambed-sediment and suspendedsediment samples collected from sites in Bexar County, Texas, 2007-09. 
Five PBDE congeners $(47,99,100,153$, and 154) were common between the Hadley Lake study and the samples collected during 2007-09 in Bexar County. Dodder and others (2002, table 2) reported $\mathrm{PBDE}$ congener concentrations ranging from less than $0.02 \mu \mathrm{g} / \mathrm{kg}$ (PBDE 190) to $22 \mu \mathrm{g} / \mathrm{kg}$ (PBDE 99), with a median concentration of $1.35 \mu \mathrm{g} / \mathrm{kg}$ and an 83 -percent detection frequency. Concentrations of these same PBDE congeners in the samples collected during 2007-09 in Bexar County ranged from less than $0.1 \mu \mathrm{g} / \mathrm{kg}$ (PBDEs 47, 99, 100, 153 , and 154) to $5.2 \mu \mathrm{g} / \mathrm{kg}$ (PBDE 47), with a median concentration of $0.34 \mu \mathrm{g} / \mathrm{kg}$ and a 45 -percent detection frequency.

PAHs are ubiquitous in the urban environment and are derived from numerous sources. Common sources in urban settings include automobile exhaust, used motor oil, automobile tire particles, parking lot sealcoat, and burning wood, oil, coal, or other combustibles for cooking, heating, or energy production; the relative contribution of PAHs to sediments from each of these sources varies (Van Metre and Mahler, 2010). PAHs rarely occur in the environment as individual compounds but are present as complex mixtures. PAHs are potential human health hazards; several PAH compounds, known as B2 PAHs, have been identified as probable carcinogens (U.S. Environmental Protection Agency, 1993). In this report, total PAH is the sum of 12 compounds: acenaphthene, acenaphthylene, anthracene, benz(a)anthracene, benzo(a) pyrene, chrysene, dibenzo(a,h)anthracene, fluoranthene, fluorene, naphthalene, phenanthrene, and pyrene (Ingersoll and others, 2001; 2-methylnaphthalene not included because not measured by the NWQL). PAHs were most frequently detected in the Leon Creek and San Antonio River watersheds (appendix 1.3). The greatest total PAH concentrations were measured in a streambed-sediment sample collected in 2007 from the Leon Rodriguez site $(4,000 \mu \mathrm{g} / \mathrm{kg})$ and in an LVSS sample collected in 2008 from the SAR 410 site $(3,600 \mu \mathrm{g} / \mathrm{kg})$. Land use in the contributing area of the Leon Rodriguez site is typical of the study area (table 2) and therefore provides no insight to the relatively high PAH concentrations measured in the streambed-sediment sample collected from the site. Total PAH concentrations in streambed-sediment samples collected at the Leon Rodriguez site in $2008(170 \mu \mathrm{g} / \mathrm{kg})$ and 2009 (260 $\mu \mathrm{g} / \mathrm{kg}$ ) were not similarly high. Relatively high total PAH concentrations in sediment samples collected from the SAR 410 site are expected because of the relatively high percentages of residential, commercial, industrial, and transportation land use in the contributing area of the SAR 410 site compared to these land uses in contributing areas of other sites in the study area. The land use in the contributing area of the SAR Theo site is similar to that of the SAR 410 site, and total PAH concentrations in streambed-sediment samples collected from the SAR Theo site $(1,500 \mu \mathrm{g} / \mathrm{kg})$ and SAR 410 site $(2,000,760$, and 460 $\mu \mathrm{g} / \mathrm{kg}$ ) were similarly high. PAHs were not detected often and only at relatively low concentrations in the samples collected at sites on Medio Creek, Medina River, Elm Creek, Martinez Creek, and Chupaderas Creek (appendix 1.3); contributing areas for these sites are among the most undeveloped in the study area.
Kendall's tau nonparametric correlation coefficients (Helsel, 2005) were computed to measure the strength of association between SSC and LVSS contaminant concentrations. The 13 LVSS samples were collected as follows: 1 at the Medina site, 2 at the Martinez St. Hedwig site, 3 at the Leon 35 site, 2 at the Salado Southton site, 2 at the SAR 410 site, and 3 at the SAR Elmendorf site. Correlation coefficients were computed three different ways: for the entire dataset of 13 samples, for the 3 samples collected from the Leon 35 site, and for the 3 samples collected from the SAR Elmendorf site. When considering the entire dataset, Kendall tau correlation coefficients were only statistically significant (p-value less than .05 ) for dieldrin (tau $=.416$; $\mathrm{p}$-value $.048 ; 8$ nondetections) and $p, p^{\prime}$-DDD (tau $=.414$; $\mathrm{p}$-value $.049 ; 10$ nondetections). Tau correlation coefficient values closer to +1.0 indicate a stronger, positive association between the variables; tau values closer to -1.0 indicate a stronger, negative association; and tau values near 0 indicate the variables are unrelated (Helsel and Hirsch, 2002). There were no statistically significant correlations between the SSC and LVSS contaminant concentrations for the datasets from the Leon 35 or SAR Elmendorf sites, which both had small sample sizes.

Loads were not computed using the LVSS samples collected in Bexar County during 2007-09; in some studies, an estimate of load (total mass of contaminant per storm) can be computed by using the contaminant concentration, SSC, and volume of stormwater (Mahler and others, 2006). Mahler and others (2006) measured sediment chemistry and mass in discreet samples over the storm hydrograph; contaminant concentrations were typically greatest in the first-flush samples, but the SSC was typically greatest in the samples collected at peak flow. When temporal loads were computed over a hydrograph, the variations in loads generally followed the same form as the hydrograph because the contaminant load was a function of sediment load. The first-flush samples collected during 2007-09 do not provide adequate information to compute contaminant loads. Additional measurements of SSC and contaminant concentrations over the hydrograph, stream discharge measurements, and stormwater samples from the center of the stream channel using an isokinetic sampler (intake does not change velocity of stream water) would be needed to provide meaningful estimates of loads. The addition of automatic water samplers at existing streamflow-gaging locations could provide the measurements and stormwater samples needed to compute loads.

Selected trace element and organic contaminant concentrations were compared between streambed-sediment and LVSS samples. A previous investigation of sediments in Fort Worth watersheds determined that the concentrations of most trace elements in streambed and suspended sediments were similar, whereas concentrations of organic contaminants in suspended sediments were often higher compared to concentrations in streambed sediments (Van Metre and others, 2003). The contaminant concentrations in the Bexar County streambed-sediment and LVSS samples varied similarly (fig. 9). The median ratio of median LVSS contaminant concentrations to 

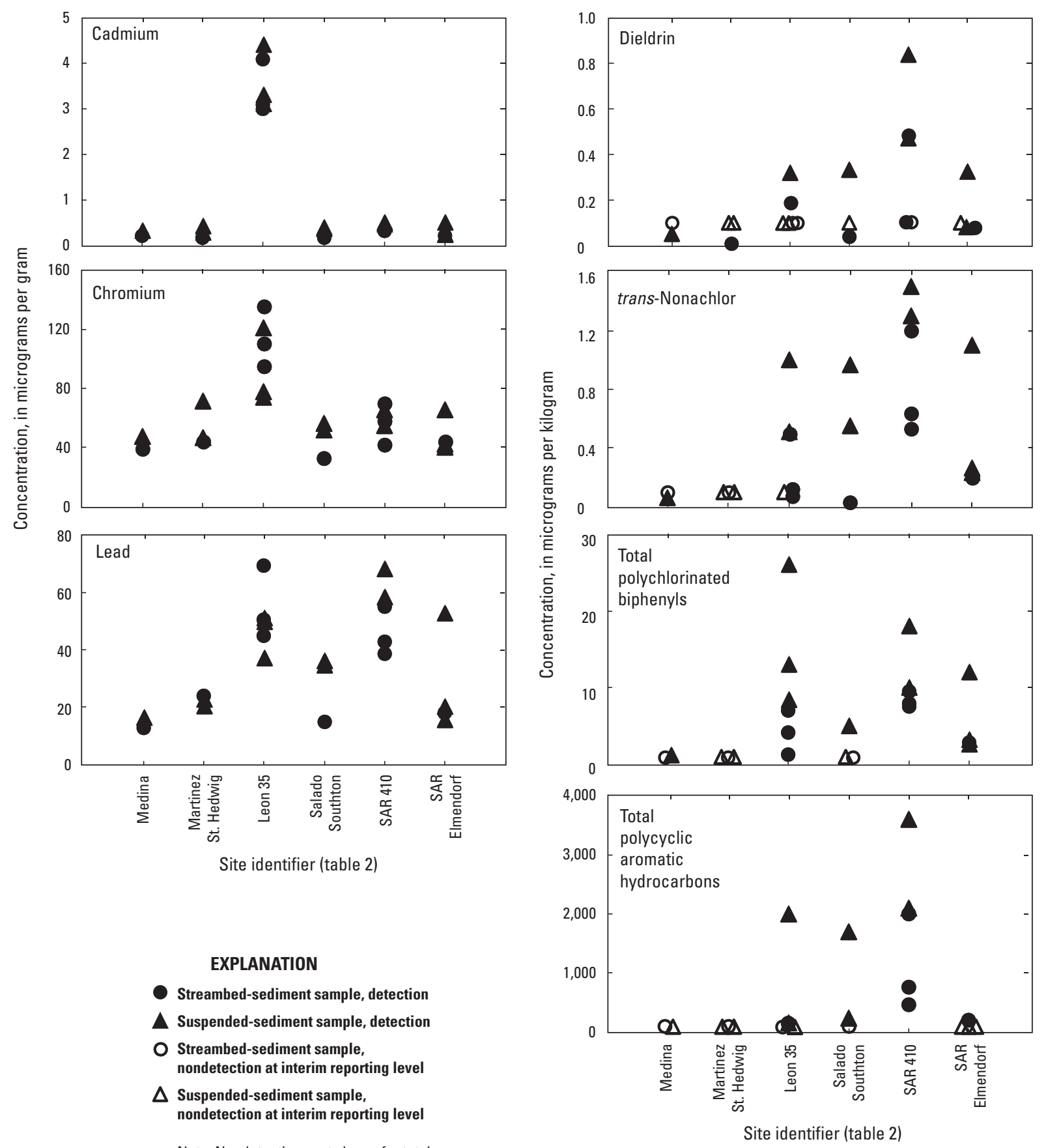

Figure 9. Comparison of concentrations of selected contaminants in streambed-sediment samples to concentrations in suspendedsediment samples collected from selected sites in Bexar County, Texas, 2007-09. 
median streambed-sediment contaminant concentrations was 1.18 for trace elements and 3.16 for organic contaminants. Van Metre and others (2003) proposed two hypotheses to explain the difference in streambed- and suspended-sediment contaminant concentrations: (1) LVSS contaminant concentrations are highly variable and typical concentrations are not well represented by a small sample size; and (2) contaminants are removed during transport and deposition through desorption as organic carbon breaks down, or by microbial degradation or bioaccumulation of the contaminants. Another possible explanation is that streambed sediments are typically coarser, even after sieving, than suspended sediments resulting in less surface area per given mass of sediment for adsorption of contaminants. This could also be related to differences in organic carbon values in streambed-sediment samples compared to values in LVSS samples. However, the median organic carbon values in streambed-sediment and LVSS samples collected during 2007-09 were 1.92 and 2.05 percent, respectively; for 36 streambed-sediment and 13 LVSS samples, the distributions in the two groups did not differ significantly at the 95-percent confidence level ( $\mathrm{p}$-value $<.05$ ) according to the Mann-Whitney test results (two-sided p-value $=.41$ ). The Mann-Whitney test is described in detail in Helsel and Hirsch (2002).

\section{Comparison of Findings to Sediment-Quality Guidelines}

Sediment contaminant concentrations can be compared to SQGs to determine the degree of contamination. The SQGs used in this report are not regulatory limits but benchmarks to evaluate the potential toxicity of bed sediment to biota. SQGs have been published by research scientists and government agencies to evaluate the potential toxicity of sediment-associated contaminants to benthic biota (for example, Ingersoll and others, 2000; MacDonald, Ingersoll, and Berger, 2000; Texas Commission on Environmental Quality, 2010a). SQGs were developed for streambed sediment but not for suspended sediment; however, the LVSS sample concentrations were evaluated relative to SQGs for comparisons between sites.

There are typically two SQG concentration levels-a lower level, below which adverse effects to aquatic biota are not expected, and a higher level, above which adverse effects are expected to occur. MacDonald, Ingersoll, and Berger (2000) developed consensus-based SQGs from numerous sets of published guidelines (table 5). The threshold effect concentration (TEC), or lower level, and probable effect concentration (PEC), or higher level, of MacDonald, Ingersoll, and Berger (2000) were used to evaluate the concentrations of trace elements, halogenated organic compounds, and PAHs in the streambed-sediment and LVSS samples collected during 2007-09. Sediment-contaminant concentrations less than the TEC should not have a harmful effect on sediment-dwelling organisms, whereas concentrations greater than the PEC are likely to have a harmful effect (MacDonald, Ingersoll, and
Berger, 2000). TCEQ, the environmental enforcement agency for the State, publishes screening levels for sediment similar to SQGs (Texas Commission on Environmental Quality, 2010a); many of these screening levels are based on the SQGs published by other researchers. All TCEQ sediment screening levels for the trace elements, halogenated organic compounds, and PAHs discussed in this section are identical to the higherlevel PECs of MacDonald, Ingersoll, and Berger (2000).

There are consensus-based SQGs for eight trace elements: arsenic, cadmium, chromium, copper, lead, mercury, nickel, and zinc. Generally, concentrations of trace elements in the samples collected during 2007-09 were low compared to SQGs (fig. 10). Trace element concentrations were greater than the PEC in 1.5 percent of the samples and greater than the TEC in 28 percent of the samples. Chromium concentrations exceeded SQGs more frequently than concentrations of any other constituents (greater than the TEC and PEC in 69 and 8 percent of samples, respectively). The PECs for both cadmium and chromium were exceeded in the two samples collected from the Leon Quintana site. The PEC for chromium also was exceeded in two samples collected from the Leon 35 site. The trace elements most frequently detected at concentrations greater than the TEC were chromium and lead (69 and 33 percent of all analyses, respectively), then zinc (35 percent), nickel (20 percent), cadmium (16 percent), arsenic (12 percent), and copper (10 percent). No concentrations of mercury were greater than the TEC (fig. 10). On the basis of the percentages of concentrations greater than the TEC for all eight trace elements, the greatest amounts of trace elements in the sediments were at the Leon Quintana (63 percent), Leon 35 (54 percent), and SAR 410 (48 percent) sites; the least amounts of trace elements in the sediments were at the Leon Rodriguez (8 percent), Medina (6 percent), Elm (0), and SAR Theo (0) sites. The SAR Theo site is about $9.7 \mathrm{~km}$ upstream from the SAR 410 site; trace element concentrations at these sites were expected to be similar. However, construction activities observed on the stream channel during the collection of samples at the SAR Theo site are believed to have increased sediment contributions at this site and diluted the trace element concentrations. There is no consensus-based SQG for silver, however the National Oceanic and Atmospheric Administration (Buchman, 2008) provides screening guidelines for silver in marine sediments at a lower level (effects range low-ERL) of $1.0 \mu \mathrm{g} / \mathrm{g}$ and a higher level (effects range median-ERM) of $3.7 \mu \mathrm{g} / \mathrm{g}$. Silver concentrations were less than the method detection level of $1 \mu \mathrm{g} / \mathrm{g}$ at all sites except the Leon Quintana and Leon 35 sites. In two streambed-sediment samples collected from the Leon Quintana site, silver concentrations were $3.8 \mu \mathrm{g} / \mathrm{g}$, which exceeded the ERM. Silver concentrations ranged from 1.5 to $2.5 \mu \mathrm{g} / \mathrm{g}$ in samples from the Leon 35 site. High trace element concentrations occurred most frequently in the Leon Creek watershed downstream from the former Kelly AFB where activities that involved the use and disposal of trace elements, such as electroplating and chrome plating sludge and paint disposal, were known to occur (CH2M Hill, 2001). 

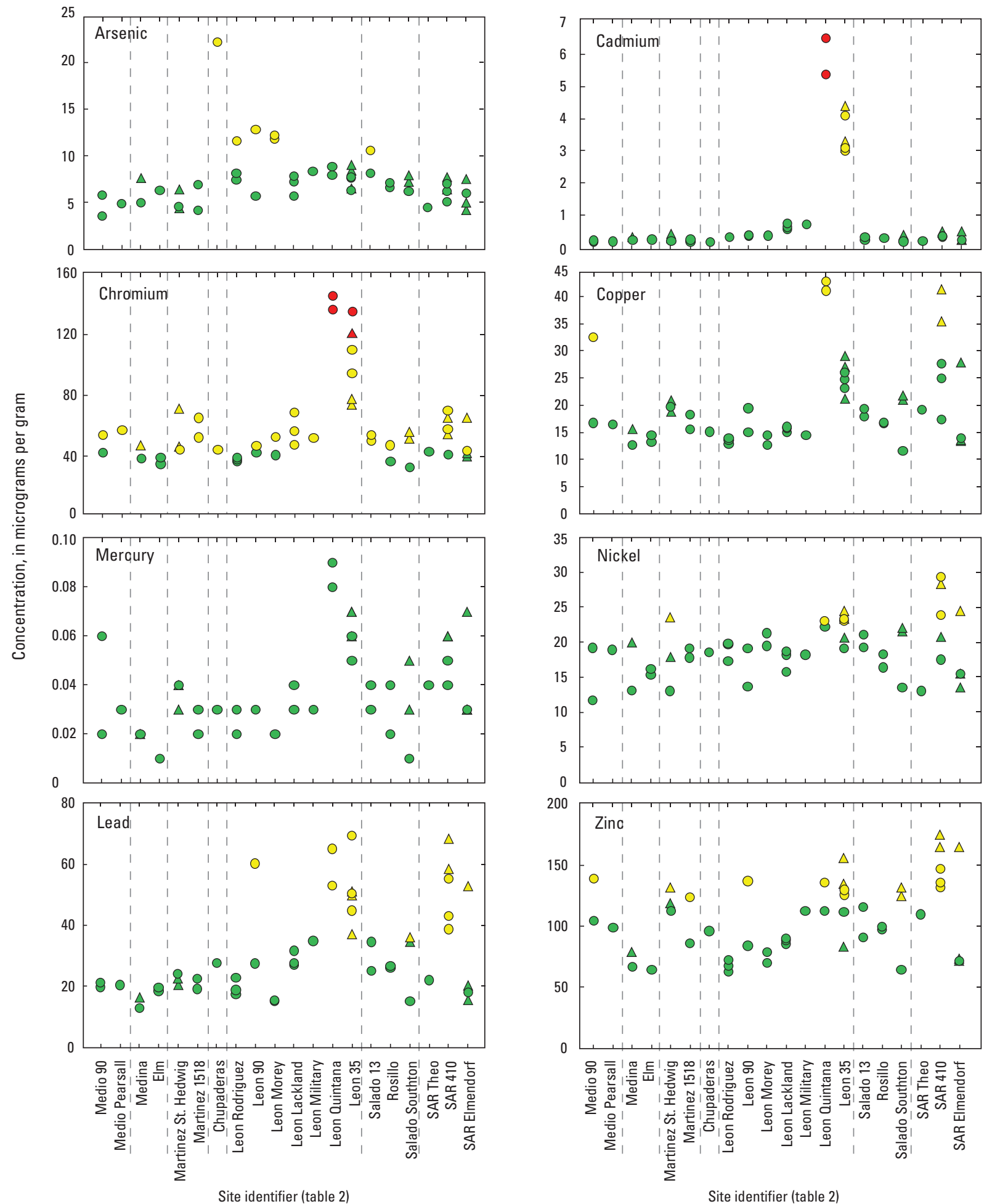

EXPLANATION

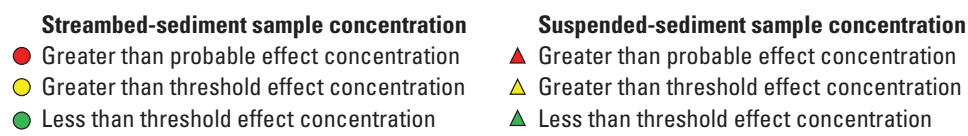

Figure 10. Comparison of consensus-based sediment-quality guidelines (MacDonald, Ingersoll, and Berger, 2000) with concentrations of selected trace elements in streambed-sediment and suspended-sediment samples collected from sites in Bexar County, Texas, 2007-09. 
Table 5. Consensus-based sediment-quality guidelines used for comparison to contaminant concentrations in streambedsediment and suspended-sediment samples collected from sites in Bexar County, Texas, 2007-09.

$[\mu \mathrm{g} / \mathrm{g}$, micrograms per gram; $\mu \mathrm{g} / \mathrm{kg}$, micrograms per kilogram; PCBs, polychlorinated biphenyls; PAHs, polycyclic aromatic hydrocarbons]

\begin{tabular}{lcc}
\hline \multicolumn{1}{c}{ Constituent } & $\begin{array}{c}\text { Threshold effect } \\
\text { concentration }\end{array}$ & $\begin{array}{c}\text { Probable effect } \\
\text { concentration }\end{array}$ \\
\hline Arsenic & Trace elements $(\mu \mathrm{g} / \mathrm{g})$ & \\
Cadmium & 9.79 & 33.0 \\
Chromium & .99 & 4.98 \\
Copper & 43.4 & 111 \\
Lead & 31.6 & 149 \\
Mercury & 35.8 & 128 \\
Nickel & .18 & 1.06 \\
Zinc & 22.7 & 48.6 \\
\hline & 121 & 459 \\
\hline Chlordane & Halogenated organic compounds $(\mu \mathrm{g} / \mathrm{kg})$ \\
Dieldrin & 3.24 & 17.6 \\
DDD & 1.90 & 61.8 \\
DDE & 4.88 & 28.0 \\
DDT & 3.16 & 31.3 \\
Total PCBs & 4.16 & 62.9 \\
\hline & 59.8 & 676 \\
\hline
\end{tabular}

Polycyclic aromatic hydrocarbons $(\mu \mathrm{g} / \mathrm{kg})$

\begin{tabular}{lcr}
\hline Anthracene & 57.2 & 845 \\
Benzo(a)pyrene & 150 & 1,450 \\
Benz(a)anthracene & 108 & 1,050 \\
Chrysene & 166 & 1,290 \\
Dibenzo(a,h)anthracene & 33.0 & none \\
Fluoranthene & 423 & 2,230 \\
Fluorene & 77.4 & 536 \\
Naphthalene & 176 & 561 \\
Phenanthrene & 204 & 1,170 \\
Pyrene & 195 & 1,520 \\
Total PAHs & 1,610 & 22,800 \\
\hline
\end{tabular}

${ }^{1}$ From MacDonald, Ingersoll, and Berger (2000).
MacDonald, Ingersoll, and Berger (2000) developed consensus-based SQGs for six of the halogenated organic compounds included in the analyses of sediment samples collected during 2007-09 in Bexar County: chlordane, dieldrin, DDD, DDE, DDT, and PCBs. The halogenated organic compounds for which SQGs are recommended are not the exact same compounds that were analyzed for this study. DDD, DDE, and DDT are primarily mixtures of different isomers, and the toxicity of each isomer is different (Ginsburg, 1947). For example, technical grade DDT that was generally used as an insecticide is primarily a mixture of the isomers $p, p^{\prime}$-DDT (active ingredient, comprising 65 to 80 percent of the mixture), $o, p^{\prime}$-DDT (15 to 21 percent), and $p, p^{\prime}$-DDD (up to 4 percent) (Metcalf, 1995). MacDonald, Ingersoll, and Berger (2000) recommended SQGs for the sum of the three isomers of the DDD, DDE, and DDT compounds. However, for this report only the $p, p^{\prime}$-form of each compound was determined by the NWQL so there might be more SQG exceedances than reported here because the concentrations of the $o, p^{\prime}$ - and $o, o^{\prime}$-forms of DDT, DDD, and DDE were not measured in the samples. MacDonald, Ingersoll, and Berger (2000) defined total chlordane as the sum of the two isomers cis-chlordane and trans-chlordane, and the sum of the two isomers was computed for the sediment samples collected in 2007-09 for comparison to the SQGs. MacDonald, Dipinto, and others (2000) did not designate total PCBs as a sum of specific congeners or Aroclors, but instead derived SQGs for an intentionally undefined mixture of PCBs, referred to as total PCBs because PCBs occur as complex mixtures in field-collected sediments. In this report, total PCBs was computed as the sum of the 18 reported congeners.

Concentrations of halogenated organic compounds in the 2007-09 samples generally were low in comparison to SQGs (fig. 11). The TECs of the six halogenated organic compounds with SQGs were exceeded in 32 of 288 analyses (11 percent) and PECs were exceeded in 3 of 288 analyses (1 percent). The PECs of DDT, DDD, and DDE were exceeded in one streambed-sediment sample collected from the Leon Lackland site on December 3, 2007 (110 $\mu \mathrm{g} / \mathrm{kg}$ of $p, p^{\prime}$-DDT, $55 \mu \mathrm{g} / \mathrm{kg}$ of $p, p^{\prime}$-DDD, and $41 \mu \mathrm{g} / \mathrm{kg}$ of $p, p^{\prime}$-DDE). DDD and DDE, in addition to composing part of the technical grade of DDT, are the most common metabolites of DDT; under aerobic conditions DDT degrades to DDE and under anaerobic conditions degrades to DDD (Spencer and Cliath, 1972). Although DDD and DDE were detected less frequently than other halogenated organic compounds, most detected concentrations exceeded the TECs. DDT was detected in 13 percent of the samples with 67 percent of those detections exceeding the TEC. DDD and DDE were detected in 19 and 35 percent of the samples with 78 and 53 percent of those detections exceeding the TECs, respectively. Chlordane compounds were detected in 94 percent of the samples and 6 percent of the analyses of cis-chlordane plus trans-chlordane were greater than the TEC. All dieldrin concentrations were less than the TEC of $1.90 \mu \mathrm{g} / \mathrm{kg}$. Only one sample exceeded the TEC for 



Site identifier (table 2)

\section{EXPLANATION}

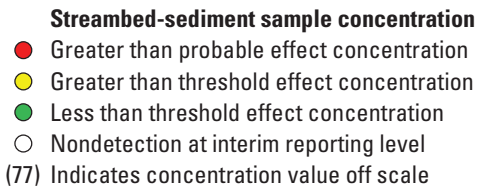

Greater than probable effect concentration

Greater than threshold effect concentration

(77) Indicates concentration value off scale
Suspended-sediment sample concentration

$\triangle$ Greater than threshold effect concentration

$\triangle$ Less than threshold effect concentration

$\triangle$ Nondetection at interim reporting level

Note: Nondetections not shown for cis-chlordane plus

trans-chlordane and for total polychlorinated biphenyls

Figure 11. Comparison of consensus-based sediment-quality guidelines (MacDonald, Ingersoll, and Berger, 2000) with concentrations of selected halogenated organic compounds in streambed-sediment and suspended-sediment samples collected from sites in Bexar County, Texas, 2007-09. 
total PCBs-the streambed-sediment sample collected from the Leon Lackland site on December 3, 2007.

Consensus-based SQGs were developed for several individual PAH compounds (anthracene, benz(a)anthracene, benzo(a)pyrene, chrysene, dibenzo(a,h)anthracene, fluorene, fluoranthene, naphthalene, phenanthrene, and pyrene) and total PAHs (MacDonald, Ingersoll, and Berger, 2000). The five PAHs with the highest average concentrations (benzo(a) pyrene, chrysene, fluoranthene, phenanthrene, and pyrene) and total PAH were selected for comparison to the SQGs (fig. 12). The TECs of the six selected PAHs were exceeded in 40 of 288 analyses (14 percent). None of the PAH concentrations exceeded the PECs. The PAH concentrations were typically highest in samples collected from the following sites: Leon Rodriguez, Leon Lackland, Leon 35, Salado Southton, and SAR 410. PAHs were not detected in the samples collected from the Medina and Chupaderas sites, except for perylene and 2,6-dimethylnaphthalene, which are not necessarily indicative of human-related contamination. Perylene is thought to be produced by in situ diagenesis under anoxic conditions and typically occurs in aquatic sediments a few centimeters below the sediment-water interface (Gschwend and others, 1983; Silliman and others, 1998). A study of water quality in the upper Snake River watershed in Idaho and Wyoming attributed frequent detections of 2,6-dimethylnaphthalene to industrial and recreational activities (Clark and others, 1998, p. 16). During sampling for the USGS NAWQA Contaminant Trends in Lake Sediments Program (Van Metre and others, 2004), 2,6-dimethylnaphthalene was frequently detected in streambed, suspended, and lake bottom sediments regardless of land use in the watersheds, possibly because of a problem with the analytical method that was used (Barbara Mahler, U.S. Geological Survey, written commun., 2006).

The overall degree of sediment contamination of the Bexar County sampling sites was assessed with the mean PEC quotient (MacDonald, Ingersoll, and Berger, 2000). The mean PEC quotient is derived by using the three groups of constituents for which consensus-based SQGs exist-trace elements, halogenated organic compounds, and PAHs. To compute the mean PEC quotient, the concentration of each constituent is divided by its respective PEC to get the individual PEC quotient, and then the individual PEC quotients are summed for each sample and divided by the number of PEC quotients to get the mean PEC quotient. Nondetected concentrations were included in the mean PEC quotient computations by following the procedures that Helsel (2009) used for toxic equivalence factors and by using the Kaplan-Meier procedure. The mean PEC quotient for the streambed-sediment sample collected from the Martinez 1518 site on August 11, 2009, included only the trace element concentrations because no halogenated organic compound or PAH concentrations were available (sample jar broke during shipment to analytical laboratory). Mean PEC quotients provide a basis for predicting sediment toxicity. MacDonald, Ingersoll, and Berger (2000) determined that a mean PEC quotient greater than 0.5 is a reasonable indicator of whether the sediment is toxic to benthic biota and were able to correctly predict toxicity in 85 percent of samples tested; and the higher the mean PEC quotient, the higher the incidence of toxicity in sediments. The SQGs were not developed for suspended sediments, and using the mean PEC quotient for predicting sediment toxicity has not been shown to apply to suspended sediments, however the guidelines still provide useful benchmarks for comparing constituent concentrations measured in samples collected from the different sites. The mean PEC quotient is less than 0.5 for all but one of the samples collected in this study. The highest mean PEC quotient (0.51) was measured in the streambedsediment sample collected from the Leon Lackland site on December 3, 2007. The next highest mean PEC quotients were measured in samples collected from the Leon Quintana, Leon 35, Leon Military, and SAR 410 (in order of increasing values; fig. 13).

\section{Comparison of Findings to Data from Previous Studies}

Several studies have demonstrated that benthic organisms bioaccumulate many sediment-associated contaminants and that concentrations of sediment contaminants, particularly organic compounds, correlate positively with the concentrations of these contaminants in benthic organisms (for example, Brown and others, 1998; Chalmers, 2002). The USGS collected biological samples at the Leon 35, Salado 13, and SAR Elmendorf sites during 1995-97. Asian clam, common carp, channel catfish, gray redhorse minnow, and spotted bass were collected and analyzed for trace elements and halogenated organic compounds (appendix 3.1). All eight trace elements with SQGs were detected in at least one organism from each site except for mercury, which was not detected in the sample collected from the SAR Elmendorf site. The highest concentrations of trace elements were measured in the Asian clam sample from the Leon 35 site, except for copper and zinc, which were highest in a common carp sample from the SAR Elmendorf site in 1996. The high concentrations of trace elements measured in biological samples from the Leon 35 and SAR Elmendorf sites are consistent with trace element concentrations in the streambed-ediment and LVSS samples in this study, which were elevated frequently in samples collected from sites on Leon Creek and the San Antonio River (fig. 10). Silver was detected in both the Asian clam and common carp samples from the Leon 35 site and in one common carp sample from the SAR Elmendorf site, but not in any biological samples from the Salado 13 site. Similarly, silver was detected in all 2007-09 sediment samples from the from Leon 35 site but not in any of the sediment samples from the SAR Elmendorf or Salado Creek sites (appendix 1.1). The organic analyses of biological samples included total PCBs, dieldrin, and various forms of chlordane and DDT. Total PCB concentrations typically were highest in biological samples from the SAR Elmendorf site (appendix 3.1). In contrast, total PCB concentrations in the 2007-09 sediment samples generally 

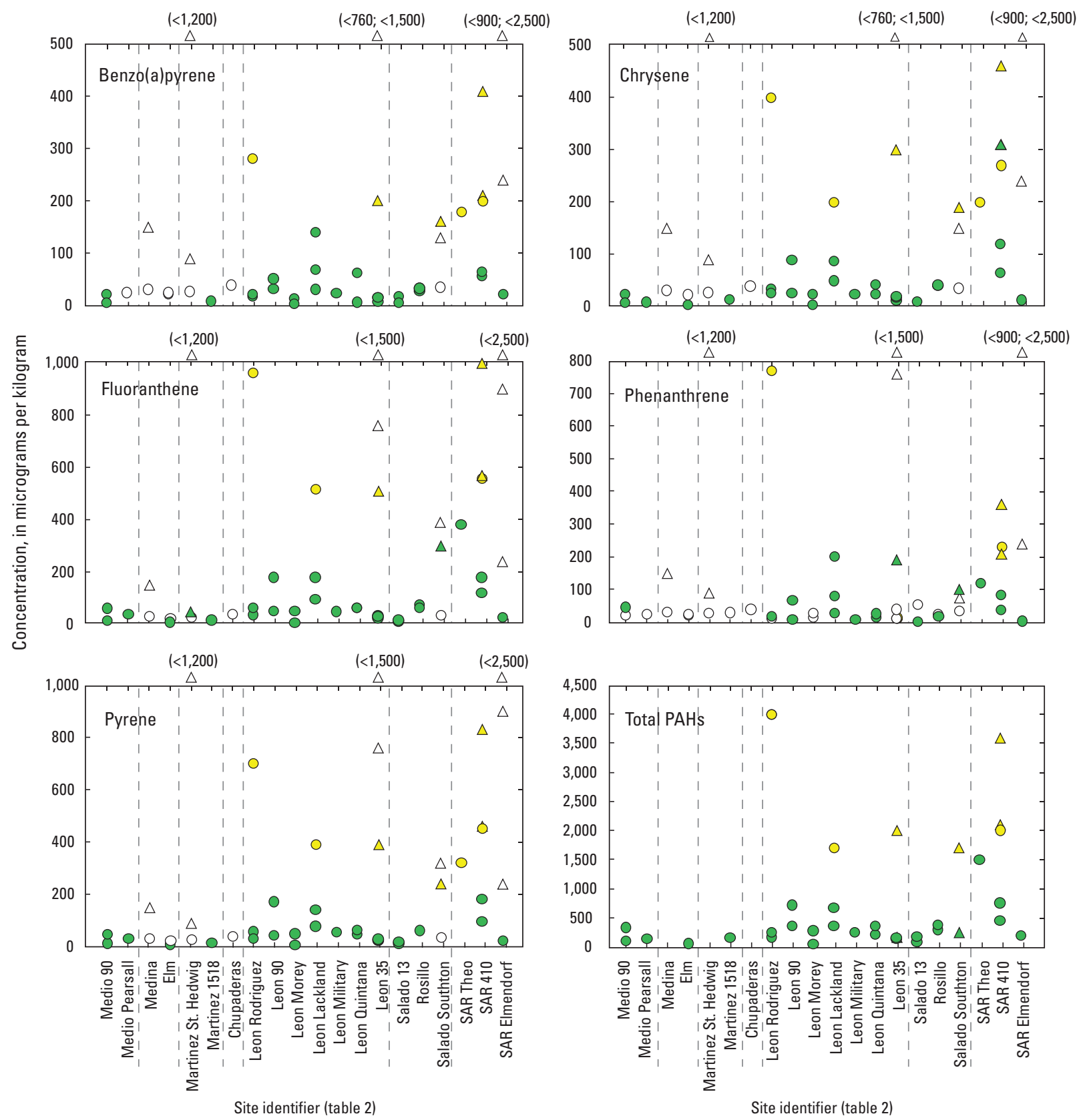

\section{EXPLANATION}

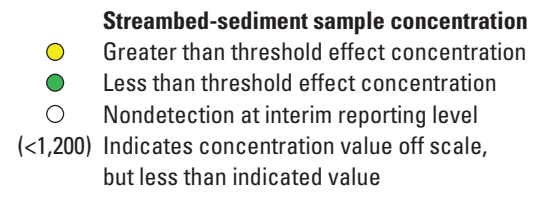

Suspended-sediment sample concentration

$\triangle$ Greater than threshold effect concentration

$\triangle$ Less than threshold effect concentration

$\triangle$ Nondetection at interim reporting level

Note: Nondetections not shown for total PAHs

Figure 12. Comparison of consensus-based sediment-quality guidelines (MacDonald, Ingersoll, and Berger, 2000) with concentrations of selected polycyclic aromatic hydrocarbons (PAHs) and total PAHs in streambed-sediment and suspended-sediment samples collected from sites in Bexar County, Texas, 2007-09. 


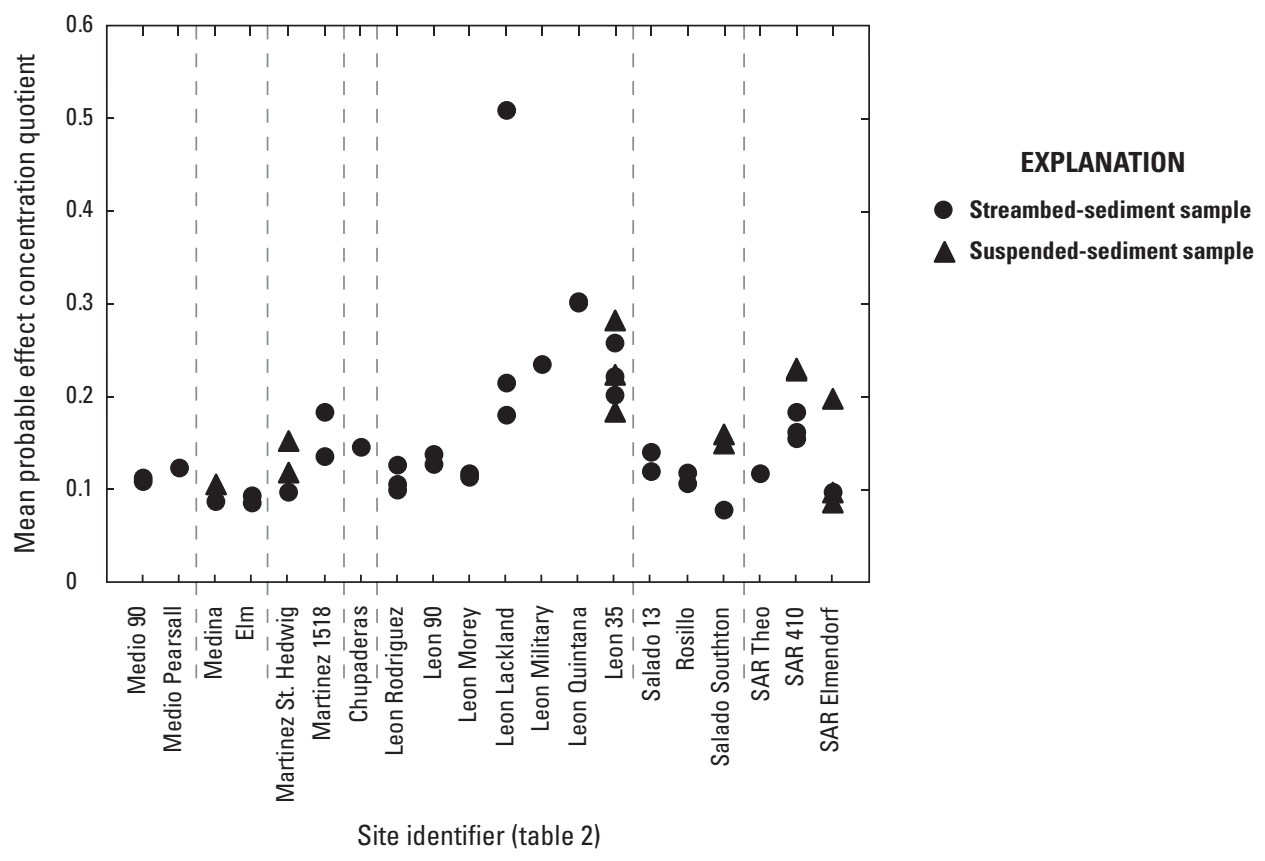

Figure 13. Mean probable effect concentration quotient of streambed-sediment and suspended-sediment samples collected from sites in Bexar County, Texas, 2007-09.

were higher at the Leon 35 site than at the SAR Elmendorf site (appendix 1.2).

The USGS collected streambed-sediment samples at the Medio Pearsall site in 1999, the Leon 35, Salado 13, and SAR Elmendorf sites in 1995 and 2001, and the SAR 410 in 2001 (appendix 3.2). These samples were analyzed for one or more of the following groups of constituents: trace elements, halogenated organic compounds, and PAHs. The 1995-2001 samples were sieved for grain size homogeneity (62 $\mu \mathrm{m}$ and 2 $\mu \mathrm{m}$ for trace elements and organic constituents, respectively) before being submitted to the laboratory for analysis (sample processing was similar during the Bexar County 2007-09 study). Most trace element concentrations were highest in the streambed-sediment sample collected in 1995 from the Leon 35 site, with six of eight concentrations exceeding the TECs. Among all trace elements, chromium concentrations were highest, exceeding the TEC of $43.4 \mu \mathrm{g} / \mathrm{g}$ in the streambedsediment samples from the Medio Pearsall, Leon 35, Salado 13, and SAR Elmendorf sites. The chromium concentrations in the 1995-99 streambed-sediment samples are similar to the chromium concentrations measured in the 2007-09 streambed-sediment and LVSS samples, where the most frequent exceedances of the TEC were for chromium (69 percent) and some of the highest concentrations were at the Leon 35 site (fig. 10). During 1995-99, silver was detected in samples from the Medio Pearsall, Leon 35, Salado 13, and SAR Elmendorf sites; the highest silver concentration was in a streambedsediment sample from the Leon 35 site (appendix 3.2). During 2007-09, silver was detected only in samples from the Leon
35 and Leon Quintana sites (appendix 1.1). Selected 1995 samples from the Leon 35, Salado 13, and SAR Elmendorf sites were analyzed for some halogenated organic compounds - various forms of chlordane and DDT, dieldrin, and total PCBs; dieldrin and total PCBs were not detected in any of these samples (appendix 3.2). In contrast, dieldrin and total PCBs were detected in some of the 2007-09 samples from the Leon 35, Salado 13, and SAR Elmendorf sites (appendix 1.2), but concentrations were less than the minimum reporting levels used to analyze samples collected in 1995. None of the halogenated organic compounds were detected in the 1995 sample collected the SAR Elmendorf site, but several halogenated organic compounds were detected in the 2007-09 samples; concentrations ranged from less than historical minimum reporting levels to more than historical minimum reporting levels. The more frequent detections of halogenated organic compounds in recent samples may be a result of the lower IRLs in the current study, sample variability, or new sourcesthe reason there were more detections is not possible to determine with the available data. Various forms of chlordane and DDT were detected in the 1995 samples from the Leon 35 and Salado 13 sites and in the 2007-09 samples from the same sites; the 1995 chlordane and DDT concentrations generally were higher than the 2007-09 concentrations. Ten streambedsediment samples collected in either 1995 or 2001 were analyzed for the 16 PAH compounds on the USEPA Priority Pollutants list (Code of Federal Regulations, 1998). The highest PAH concentrations were measured in the September 2001 sample from the Leon 35 site, in which all 16 PAHs were 
detected and total PAH was $7,000 \mu \mathrm{g} / \mathrm{kg}$ (appendix 3.2). The second highest PAH concentrations were at the SAR 410 site. PAH concentrations were less than the IRL in more than 50 percent of the samples from the SAR Elmendorf site. PAH concentrations in samples collected in either 1995 or 2001 at the Leon 35, Salado 13, and SAR Elmendorf sites are typically higher than the PAH concentrations in the 2007-09 samples from these sites. PAH concentrations exceeded TECs in an average of 28 percent of the 1995 and 2001 samples compared to an average of 14 percent of the 2007-09 samples. The data are not sufficient to determine if lower concentrations of chlordane, DDT, and PAHs in the current study relative to historical data indicate downward trends in these contaminants over time, or are a result of either sample variability or differences in analytical techniques.

The AFCEE oversees the semiannual compliance sampling near the former Kelly AFB of groundwater and Leon Creek surface water and streambed sediment. The results from streambed-sediment samples collected from eight selected AFCEE sampling sites (fig. 4) during 1994-2008 (appendix 4.0) and the results from streambed-sediment and LVSS samples collected from the Leon Creek sites during 2007-09 are compared in table 6 . The means and standard deviations were computed by using the Kaplan-Meier method when there were censored data (Helsel, 2005). Differences between the AFCEE and USGS analytical techniques make comparisons of the results somewhat uncertain. The mean concentrations of trace elements in the USGS samples are typically higher than those in the AFCEE samples. However, most of the AFCEE samples were extracted by using EPA method SW3050B (U.S. Environmental Protection Agency, 1996), which is a strong acid but not a total digestion, whereas the USGS method is a total digestion. The range of organic compound concentrations is much larger in the AFCEE samples compared to the range in the USGS samples, with numerous large outliers among the results for the AFCEE samples. Total chlordane was computed similarly for both sets of data, by using the sum of alpha- and gamma-chlordane isomers for the AFCEE samples and cis- and trans-chlordane isomers for the USGS samples. PCB Aroclors 1016, 1221, 1232, 1242, 1248, 1254, and 1260 were analyzed in the AFCEE samples. Aroclor is the industrial trade name for commercial PCB mixtures produced in the United States (Agency for Toxic Substances and Disease Registry, 2000). Total PCBs in the AFCEE samples was computed as the sum of the reported PCB Aroclors. Total PCBs in the USGS samples is the sum of 18 congeners (appendix 1.2). Total PAHs was computed as the sum of the same 12 PAH compounds in both sets of samples (acenaphthene, acenaphthylene, anthracene, benz(a)anthracene, benzo(a)pyrene, chrysene, dibenzo(a,h)anthracene, fluoranthene, fluorene, naphthalene, phenanthrene, and pyrene). All summations with censored data were computed by using the Kaplan-Meier method (Helsel, 2005). Despite differences in analytical methods, the USGS results are within concentration ranges of the AFCEE samples for all trace elements except zinc, all halogenated organic compounds except $p, p^{\prime}$-DDD and $p, p^{\prime}$-DDE, and for total PAHs (table 6). The mean concentrations of lead, mercury, dieldrin, $p, p^{\prime}$-DDE, total PCBs, and total PAHs are higher in the AFCEE samples compared to concentrations in the USGS samples. Inconsistencies in analytical methods used by the AFCEE and USGS preclude identifying changes in streambed-sediment chemistry over time, but could indicate that more frequent semiannual compliance sampling captures a wider range of contaminant concentrations than observed in the samples collected during 2007-09.

To evaluate sediment quality in Bexar County in a broader context, concentrations of sediment-associated constituents for LVSS samples collected from Bexar County streams during 2007-09 were compared with sediment-associated constituents measured in LVSS samples collected during previous studies in the Austin and Fort Worth areas (Mahler and others, 2006; Van Metre and others, 2003, respectively). The Austin and Fort Worth area studies included watersheds with land uses and background or reference conditions similar to those of the contributing areas in Bexar County, except that the Austin and Fort Worth watersheds did not have military installations. All three studies used similar LVSS sample collection and filtration methods and the same methods to analyze samples for trace elements. Mean trace element concentrations in the Bexar County LVSS samples generally were lower compared to the mean concentrations in the Austin and Fort Worth LVSS samples, but considering the relatively large ranges and standard deviations associated with the concentrations measured in all three areas, the trace element concentrations from the three areas are similar (table 7). LVSS samples for the analysis of halogenated organic compounds and PAHs from the Austin and Fort Worth areas were analyzed at the NWQL by using an older analytical method with Soxhlet extraction (Noriega and others, 2003; Olson and others, 2004) compared to the ASE method used for the Bexar County samples collected. The Soxhlet extraction method reported technical chlordane concentrations for the Austin and Fort Worth samples. The mean concentrations of the halogenated organic compounds and total PAH generally are lower in the Bexar County samples than in the Austin and Fort Worth samples but are similar overall when considering the large ranges and standard deviations.

\section{Statistical Analyses}

To compare the results obtained in the different watersheds and explore possible explanatory variables, concentrations of sediment-associated contaminants measured during 2007-09 in streambed-sediment samples collected from the sampling sites in Bexar County were evaluated by using statistical tests. LVSS samples were not included in the statistical analyses because they were not collected from all watersheds and the concentrations of organic compounds were markedly different (higher) in LVSS samples compared to concentrations in streambed-sediment samples. The Bexar County sediment contaminant concentration data set is small (less than 100 samples) and non-normally distributed 
Table 6. Percent detections, ranges, means, and standard deviations of sediment-associated constituents in sediment samples collected by the U.S. Air Force Center for Engineering and the Environment (AFCEE) during 1994-2008 and by the U.S. Geological Survey (USGS) during 2007-09 from Leon Creek in Bexar County, Texas.

$[\mu \mathrm{g} / \mathrm{g}$, micrograms per gram; $\mu \mathrm{g} / \mathrm{kg}$, micrograms per kilogram; <, nondetection (less than interim reporting level for USGS samples); PCBs, polychlorinated biphenyls; PAHs, polycyclic aromatic hydrocarbons]

\begin{tabular}{|c|c|c|c|c|c|c|c|c|c|c|}
\hline \multirow[b]{2}{*}{ Constituent } & \multicolumn{5}{|c|}{ AFCEE } & \multicolumn{5}{|c|}{ USGS } \\
\hline & $\begin{array}{c}\text { Number } \\
\text { of } \\
\text { samples }\end{array}$ & $\begin{array}{c}\text { Percent } \\
\text { detec- } \\
\text { tions }\end{array}$ & Range & Mean & $\begin{array}{l}\text { Standard } \\
\text { deviation }\end{array}$ & $\begin{array}{c}\text { Number } \\
\text { of } \\
\text { samples }\end{array}$ & $\begin{array}{c}\text { Percent } \\
\text { detec- } \\
\text { tions }\end{array}$ & Range & Mean & $\begin{array}{l}\text { Standard } \\
\text { deviation }\end{array}$ \\
\hline Arsenic $(\mu \mathrm{g} / \mathrm{g})$ & 136 & 85 & $<0.6-46.1$ & 6.6 & 5.4 & 19 & 100 & $5.7-12.8$ & 8.5 & 2.1 \\
\hline Cadmium $(\mu \mathrm{g} / \mathrm{g})$ & 136 & 78 & $<.05-26$ & 1.9 & 3.8 & 19 & 100 & $.3-6.5$ & 2.0 & 2.0 \\
\hline Copper $(\mu \mathrm{g} / \mathrm{g})$ & 136 & 98 & $<1.0-73.8$ & 11.5 & 10.0 & 19 & 100 & $12.8-42.7$ & 21.0 & 9.0 \\
\hline Lead $(\mu \mathrm{g} / \mathrm{g})$ & 136 & 100 & $5.8-1,760$ & 44.4 & 151 & 19 & 100 & $15.2-69.3$ & 37.9 & 17.2 \\
\hline Mercury $(\mu \mathrm{g} / \mathrm{g})$ & 136 & 45 & $<.004-9.5$ & .35 & 1.5 & 19 & 100 & $.02-.09$ & .04 & .02 \\
\hline Dieldrin $(\mu \mathrm{g} / \mathrm{kg})$ & 129 & 8 & $<.19-14$ & 1.5 & 10.3 & 19 & 37 & $<.1-1.1$ & .12 & .26 \\
\hline Total chlordane ${ }^{1}(\mu \mathrm{g} / \mathrm{kg})$ & 128 & 23 & $<.16-9.0$ & .71 & 1.8 & 19 & 95 & $<.2-7.8$ & 1.1 & 1.8 \\
\hline$p, p^{\prime}-\mathrm{DDD}(\mu \mathrm{g} / \mathrm{kg})$ & 120 & 39 & $<.78-51$ & 5.5 & 12.8 & 19 & 32 & $<1.0-55.0$ & 5.5 & 13.2 \\
\hline$p, p^{\prime}-\mathrm{DDE}(\mu \mathrm{g} / \mathrm{kg})$ & 120 & 67 & $<.39-37$ & 6.7 & 12.5 & 19 & 47 & $<1.0-41.0$ & 4.5 & 10.0 \\
\hline$p, p^{\prime}-\mathrm{DDT}(\mu \mathrm{g} / \mathrm{kg})$ & 118 & 42 & $<1.2-130$ & 6.6 & 15.5 & 19 & 21 & $<.1-110$ & 9.0 & 27.2 \\
\hline Total PCBs ${ }^{2}(\mu \mathrm{g} / \mathrm{kg})$ & 132 & 40 & $<2.0-2,100$ & 56.9 & 215 & 19 & 95 & $<.1-77.0$ & 9.6 & 17.6 \\
\hline
\end{tabular}

${ }^{1}$ Total chlordane is the sum of alpha and gamma-chlordane for AFCEE samples and the sum of cis-chlordane and trans-chlordane for USGS samples; USGS samples are censored at the highest interim reporting level of the individual compounds in the summation.

${ }^{2}$ Total PCBs is the sum of PCB Aroclors 1016, 1221, 1232, 1242, 1248, 1254, and 1260 for AFCEE samples and the sum of PCB congeners 49, 52, 70, 101, $110,118,138,146,149,151,170,174,177,180,183,187,194$, and 206 for USGS samples; USGS samples are censored at the highest interim reporting level of the individual compounds in the summation.

${ }^{3}$ Total PAHs is the sum of acenaphthene, acenaphthylene, anthracene, benz(a)anthracene, benzo(a)pyrene, chrysene, dibenzo(a,h)anthracene, fluoranthene, fluorene, naphthalene, phenanthrene, and pyrene (Ingersoll and others, 2001) for both sets of samples; USGS samples are censored at the highest interim reporting level of the individual compounds in the summation.

(Helsel, 2005). Concentrations are positively skewed (bulk of values below the mean) with a few high outliers (figs. 10-12), particularly for the halogenated organic compounds. Some constituents such as the halogenated organic compounds were frequently not detected. Nonparametric statistical tests were used that accounted for non-normal distributions of data, outliers, and numerous nondetected concentrations for some constituents. Statistica 9.0 was used for all statistical analyses (StatSoft, Inc., 2009) except the multiple comparison tests (Tukey's method), which were done with S-PLUS statistical analysis software (TIBCO Software Inc., 2008).

\section{Similarity or Difference of Contaminant Concentration by Watershed}

The Kruskal-Wallis test is a nonparametric test that can be used to determine the general equivalence of groups of 
Table 7. Percent detections, ranges, means, and standard deviations of selected constituents in suspended-sediment samples collected from streams in the Austin, Texas, area during 1999-2004 (Mahler and others, 2006), from streams in the Fort Worth, Texas, area during 2000-2002 (Van Metre and others, 2003), and from streams in Bexar County, Texas, during 2007-09.

[n, number of samples; $\mu \mathrm{g} / \mathrm{g}$, micrograms per gram; $\mu \mathrm{g} / \mathrm{kg}$, micrograms per kilogram; <, nondetection less than interim reporting level; PCBs, polychlorinated biphenyls; PAHs, polycyclic aromatic hydrocarbon]

\begin{tabular}{|c|c|c|c|c|c|c|c|c|c|c|c|c|}
\hline \multirow[b]{2}{*}{ Constituent } & \multicolumn{4}{|c|}{ Austin (n=61) } & \multicolumn{4}{|c|}{ Fort Worth (n=45) } & \multicolumn{4}{|c|}{ Bexar County (n=13) } \\
\hline & $\begin{array}{c}\text { Percent } \\
\text { detec- } \\
\text { tions }\end{array}$ & Range & Mean & $\begin{array}{l}\text { Standard } \\
\text { deviation }\end{array}$ & $\begin{array}{c}\text { Percent } \\
\text { detec- } \\
\text { tions }\end{array}$ & Range & Mean & $\begin{array}{l}\text { Standard } \\
\text { deviation }\end{array}$ & $\begin{array}{c}\text { Percent } \\
\text { detec- } \\
\text { tions }\end{array}$ & Range & Mean & $\begin{array}{l}\text { Standard } \\
\text { deviation }\end{array}$ \\
\hline Arsenic ( $\mu \mathrm{g} / \mathrm{g})$ & 100 & $5.5-22.8$ & 12.4 & 4.2 & 100 & $7.0-18.4$ & 11.6 & 2.4 & 100 & $4.2-9.0$ & 6.8 & 1.5 \\
\hline Cadmium $(\mu \mathrm{g} / \mathrm{g})$ & 100 & $.21-3.5$ & .70 & .68 & 100 & $.15-2.7$ & 1.1 & .7 & 100 & $.23-4.4$ & 1.1 & 1.5 \\
\hline Chromium $(\mu \mathrm{g} / \mathrm{g})$ & 100 & $28.4-94.3$ & 59.1 & 15.6 & 100 & $39.4-110$ & 66.3 & 15.3 & 100 & $40.3-121$ & 62.8 & 21.3 \\
\hline Copper $(\mu \mathrm{g} / \mathrm{g})$ & 100 & $10.3-72.9$ & 26.1 & 12.2 & 100 & $13.0-281$ & 50.0 & 47.5 & 100 & $13.4-41.3$ & 23.6 & 8.3 \\
\hline Lead $(\mu \mathrm{g} / \mathrm{g})$ & 100 & $12.6-196$ & 41.4 & 32.6 & 100 & $13.0-237$ & 94.6 & 55.2 & 100 & $15.7-68.2$ & 37.2 & 17.5 \\
\hline Mercury $(\mu \mathrm{g} / \mathrm{g})$ & 100 & $.03-.20$ & .06 & .03 & 100 & $.03-.3$ & .09 & .06 & 100 & $.02-.07$ & .05 & .02 \\
\hline Nickel $(\mu \mathrm{g} / \mathrm{g})$ & 100 & $10.7-52.3$ & 28.4 & 7.5 & 100 & $9.0-42.9$ & 28.5 & 6.6 & 100 & $13.5-28.3$ & 21.3 & 4.0 \\
\hline Zinc $(\mu \mathrm{g} / \mathrm{g})$ & 100 & $50.4-607$ & 168 & 110 & 100 & $67.3-1,600$ & 324 & 259 & 100 & $71.6-175$ & 124 & 36.8 \\
\hline Dieldrin $(\mu \mathrm{g} / \mathrm{kg})$ & 21 & $<.5-5.9$ & 1.3 & 2.2 & 65 & $<1.5-94$ & 13.8 & 19.3 & 54 & $<.1-.84$ & .22 & .25 \\
\hline Technical chlordane $^{1}(\mu \mathrm{g} / \mathrm{kg})$ & 38 & $<5.5-250$ & 28 & 39 & 76 & $<15-750$ & 160 & 180 & 77 & $<1.0-6.7$ & 2.4 & 2.1 \\
\hline$p, p^{\prime}-\mathrm{DDT}(\mu \mathrm{g} / \mathrm{kg})$ & 38 & $<.5-71$ & 8.0 & 14 & 41 & $<1.5-13,000$ & 300 & 1,900 & 0 & $<.1-<4.0$ & $\begin{array}{c}\text { Not } \\
\text { detected }\end{array}$ & $\begin{array}{c}\text { Not } \\
\text { detected }\end{array}$ \\
\hline$p, p^{\prime}-\mathrm{DDD}(\mu \mathrm{g} / \mathrm{kg})$ & 20 & $<.5-51$ & 2.6 & 7.8 & 9 & $<1.5-460$ & 13 & 77 & 31 & $<.1-16$ & 3.3 & 4.7 \\
\hline$p, p^{\prime}-\mathrm{DDE}(\mu \mathrm{g} / \mathrm{kg})$ & 61 & $<.5-70$ & 8.4 & 14 & 91 & $<1.5-620$ & 23 & 90 & 15 & $<1.0-6.2$ & 4.3 & .79 \\
\hline Total PCBs ${ }^{2}(\mu \mathrm{g} / \mathrm{kg})$ & 16 & $<16-170$ & 30 & 43 & 57 & $<45-1,220$ & 130 & 220 & 77 & $<1.0-26$ & 7.9 & 7.8 \\
\hline Total PAHs ${ }^{3}(\mu \mathrm{g} / \mathrm{kg})$ & 100 & $30.2-98,200$ & 12,800 & 22,100 & 100 & $64.3-75,200$ & 12,500 & 16,300 & 38 & $<90-3,600$ & 800 & 1,300 \\
\hline
\end{tabular}

${ }^{1}$ Technical chlordane is reported by the laboratory for Austin and Fort Worth samples; for Bexar County samples computed as sum of cis-chlordane, trans-chlordane, cis-nonachlor, trans-nonachlor, and oxychlordane and censored at highest interim reporting level of the individual compounds in the summation.

${ }^{2}$ Total PCBs is the sum of PCB Aroclors 1242, 1254, and 1260 for Austin and Fort Worth samples and the sum of PCB congeners 49, 52, 70, 101, 110, 118, 138, 146, 149, 151, 170, 174, 177, 180, 183, 187, 194, and 206 for Bexar County samples; Bexar County samples censored at highest interim reporting level of the individual compounds in the summation.

${ }^{3}$ Total PAHs is the sum of acenaphthene, acenaphthylene, anthracene, benz(a)anthracene, benzo(a)pyrene, chrysene, dibenzo(a,h)anthracene, fluoranthene, fluorene, naphthalene, phenanthrene, and pyrene; Bexar County samples censored at highest interim reporting level of the individual compounds in the summation. 
data (Helsel and Hirsch, 2002). Data from sampling sites were grouped by watershed, and the Kruskal-Wallis test was used in an attempt to answer the question: "Are contaminant concentrations the same or different among all the watersheds?" A minimum of five samples is required to perform the test, which restricted the assessment to the Leon Creek, Salado Creek, and San Antonio River watersheds. Different IRLs were frequently used for the same organic compounds depending on the mass of sample available for analysis. If some concentrations for a given constituent were nondetected concentrations, all values less than the highest IRL, including detections, were censored at the highest IRL so that they were ranked equally (Helsel, 2005). The null hypothesis that all groups had identical distributions and that the data were one group was rejected when the p-value was less than .05 , providing a 95-percent confidence level. The alternate hypothesis is that at least one of the distributions is different than one of the other distributions. The Kruskal-Wallis test results did not indicate a statistically significant difference among the concentrations of chromium, copper, mercury, nickel, lead, zinc, or silver in streambed-sediment samples collected from the Leon Creek, Salado Creek, and San Antonio River watersheds (table 8). Test results did indicate a statistically significant difference among arsenic and cadmium concentrations from the three watersheds. The test results also did not indicate a statistically significant difference among concentrations of dieldrin, total chlordane, $p, p^{\prime}$-DDT, $p, p^{\prime}$-DDD, $p, p^{\prime}$-DDE, or total PAH from the three watersheds; however, the test results did indicate a statistically significant difference among total PCB concentrations.

Tukey's multiple comparison test was used to determine which watersheds are different following the rejection of the null hypothesis for arsenic, cadmium, and total PCB concentrations by using the Kruskal-Wallis test. The Tukey's test computes a least significant range, or the distance between any two means that must be exceeded for the two groups to be considered significantly different, and is a powerful multiple comparison test for unequal sample sizes. The streambedsediment concentrations were rank transformed and Tukey's test was performed on the ranks for a nonparametric multiple comparison test (Helsel and Hirsch, 2002). Arsenic concentrations in the streambed-sediment samples from the Leon Creek watershed were significantly higher compared to concentrations from the San Antonio River watershed (p-value less than .05). The cadmium concentrations from the Leon Creek watershed were significantly higher compared to concentrations from the Salado Creek and San Antonio River watersheds ( $p$-value less than .05). Total PCB concentrations from the San Antonio River watershed were significantly higher compared to concentrations from the Salado Creek watershed (p-value less than .05). No statistical differences were determined between total PCB concentrations from the Leon Creek watershed compared to concentrations from the Salado Creek watershed or San Antonio River watershed. The large range of total PCB concentrations in the Leon Creek samples (multiple nondetected concentrations and some concentrations as high as 77 and $16 \mu \mathrm{g} / \mathrm{kg}$ ) is such that differences among watersheds could not be determined statistically even though mean total PCB concentrations in the streambed-sediment samples from each watershed are substantially different (Leon Creek, $9.2 \mu \mathrm{g} / \mathrm{kg}$; Salado Creek, no detected concentrations; and San Antonio River, $6.6 \mu \mathrm{g} / \mathrm{kg}$ ).

\section{Relations Between Land Use and Streambed- Sediment Contaminant Concentrations}

The nonparametric Mann-Whitney U (rank-sum) test was used to assess whether contaminant concentrations in streambed-sediment samples measured in the various watersheds in the study area differed depending on the presence or absence of suspected contaminant sources - military installations, USEPA Superfund sites, and USEPA Toxics Release Inventory (TRI) Program facilities and industries - in the watersheds. For example, the relations among six military installations and contaminant concentrations measured at sampling sites associated with each installation were assessed (fig. 14; table 9). Sixteen USEPA Superfund sites in the contributing areas of sediment-sampling sites reported releases of trace elements and PAHs (U.S. Environmental Protection Agency, 2010d) that were among the constituents analyzed in this study. Twenty-five USEPA TRI Program facilities and industries in the contributing areas of sediment-sampling sites also reported releases of trace elements and PAHs common to the constituents analyzed in this study (U.S. Environmental Protection Agency, 2010e). If some reported concentrations for a given constituent in a streambed-sediment sample were nondetected concentrations, all reported values less than the highest IRL, including detections, were censored to a common value so they were ranked equally (Helsel, 2005). For computed totals, such as total chlordane and total PCBs, data were censored at the highest IRL of the individual compounds summed. The results of the Mann-Whitney $\mathrm{U}$ test indicate that the presence of military installations is associated with statistically significant (p-value less than .05) higher concentrations of chromium, mercury, zinc, total chlordane, $p, p^{\prime}$-DDE, and total PCBs in the watersheds where those military installations are located. The test results also indicate that the presence of USEPA Superfund sites and TRI Program facilities and industries had no statistically significant relation to sediment contaminant concentrations in the watersheds where those sites, facilities, or industries are present (table 10).

Kendall's tau nonparametric correlation coefficients were computed to measure the strength of the relation among population, land uses (fig. 2; table 2), or PSOCs (fig. 3) in all 20 contributing areas of each sampling site and the median streambed-sediment constituent concentrations measured at each sampling site (table 11). Data were censored at the highest IRL when computing the medians and the Kendall's tau statistic. Tau correlation coefficient values closer to +1.0 indicate a stronger, positive association between the variables; tau values closer to -1.0 indicate a stronger, negative association; 


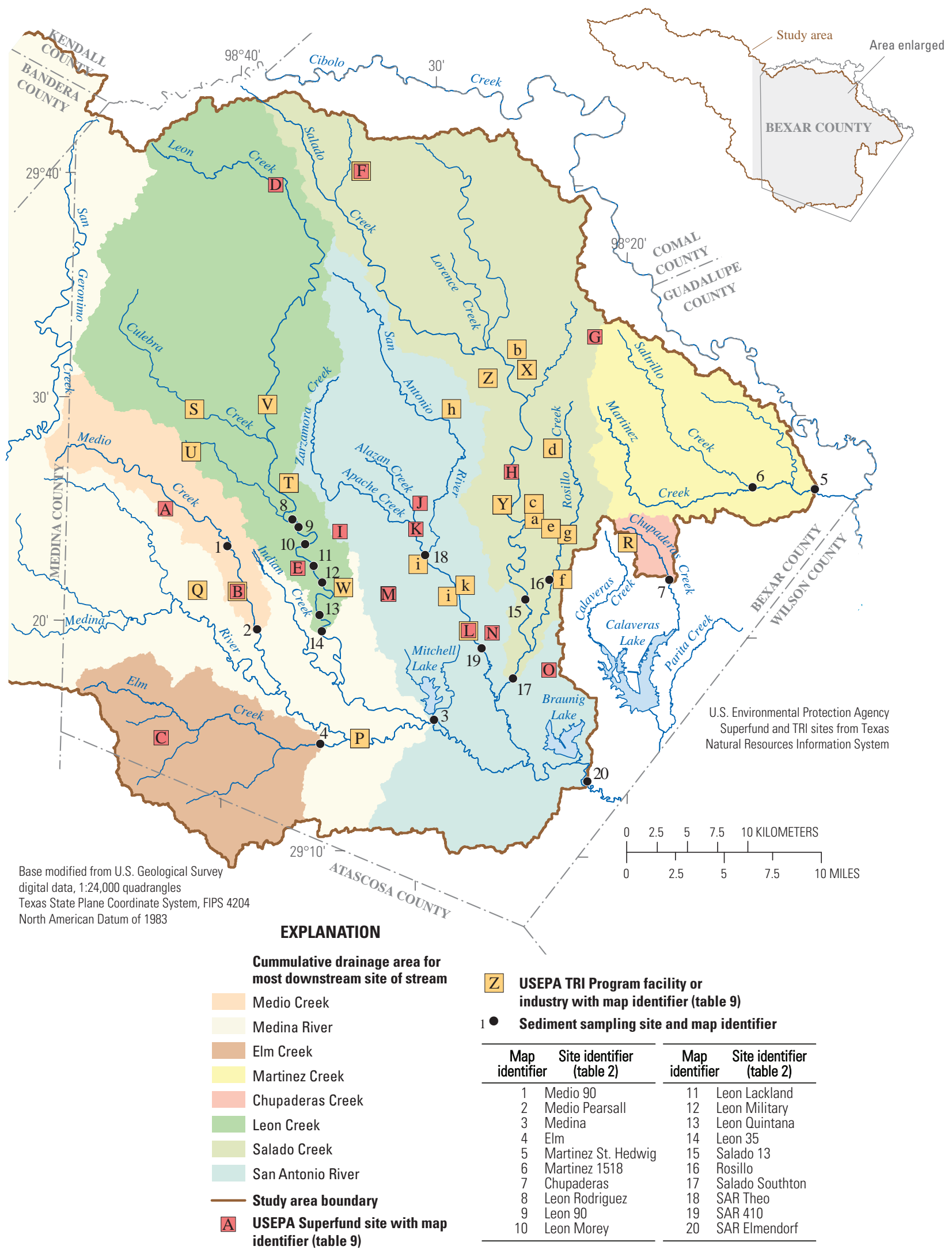

Figure 14. Locations of U.S. Environmental Protection Agency (USEPA) Superfund sites and Toxics Release Inventory (TRI) Program facilities and industries in contributing areas of streambed-sediment sampling sites in Bexar County, Texas, 2007-09 (Superfund and TRI sites from U.S. Environmental Protection Agency, 2010d, e). 
Table 8. Results of Kruskal-Wallis nonparametric tests for differences among trace element, halogenated organic compound, and polycyclic aromatic hydrocarbon concentrations in streambed-sediment samples from sample-collection sites in Bexar County, Texas, 2007-09.

$[\mu \mathrm{g} / \mathrm{g}$, micrograms per gram; <, nondetection less than lower reporting limit (silver) or less than interim reporting level (organic compounds); $\mu \mathrm{g} / \mathrm{kg}$, micrograms per kilogram; PCBs, polychlorinated biphenyls; PAHs, polycyclic aromatic hydrocarbons; shaded cells indicate statistically significant tests (p-values less than $.05)]$

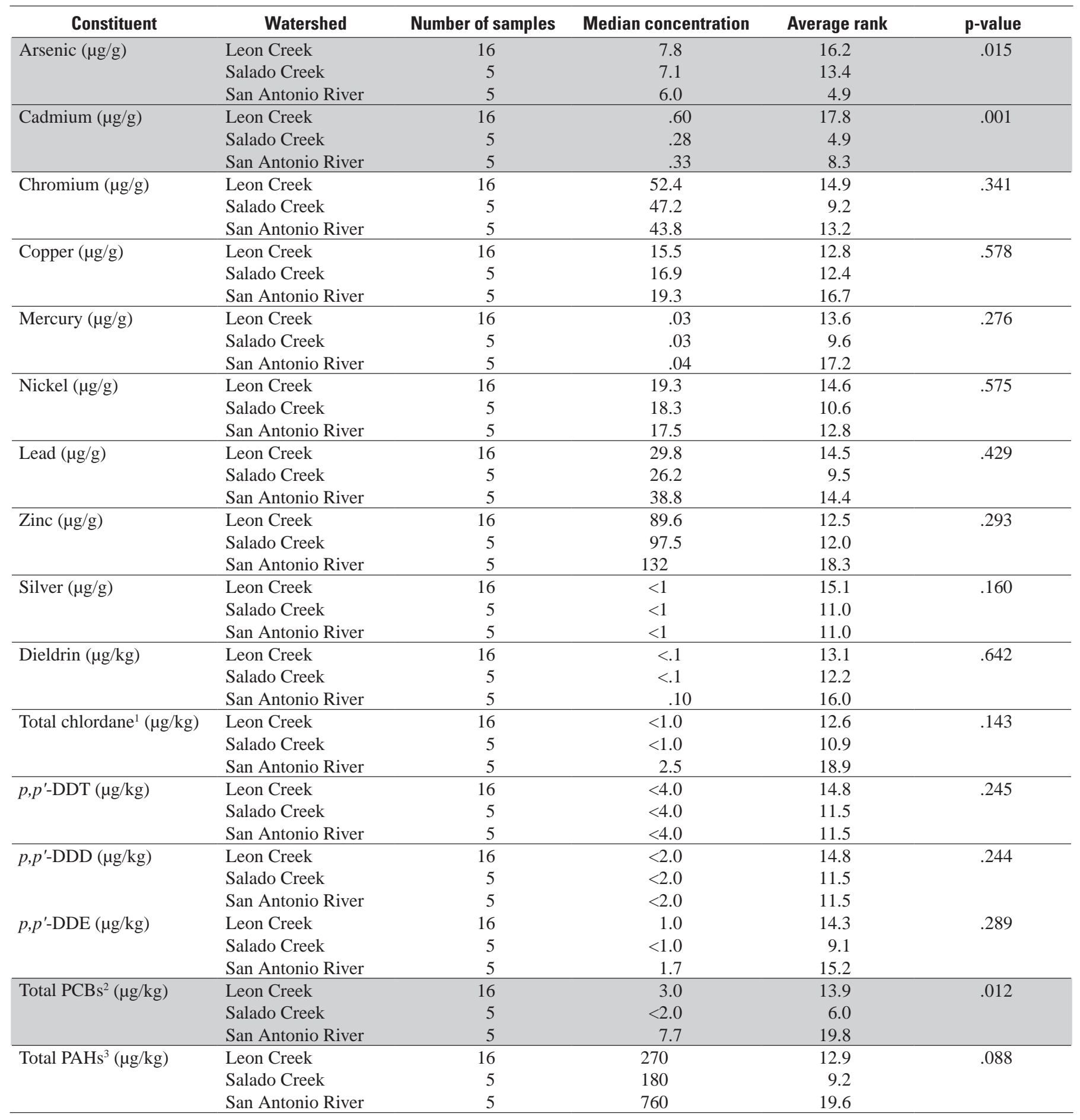

${ }^{1}$ Total chlordane is the sum of cis-chlordane, trans-chlordane, cis-nonachlor, trans-nonachlor, and oxychlordane; censored at the highest interim reporting level of the individual compounds in the summation.

${ }^{2}$ Total PCBs is the sum of PCB congeners 49, 52, 70, 101, 110, 118, 138, 146, 149, 151, 170, 174, 177, 180, 183, 187, 194, and 206; censored at the highest interim reporting level of the individual compounds in the summation.

${ }^{3}$ Total PAHs is the sum of acenaphthene, acenaphthylene, anthracene, benz(a)anthracene, benzo(a)pyrene, chrysene, dibenzo(a,h)anthracene, fluoranthene, fluorene, naphthalene, phenanthrene, and pyrene. 
Table 9. Military installations, U.S. Environmental Protection Agency Superfund sites, and U.S. Environmental Protection Agency Toxics Release Inventory Program facilities and industries in the contributing areas of the streambed-sediment sampling sites in Bexar County, Texas, 2007-09.

[--, not applicable]

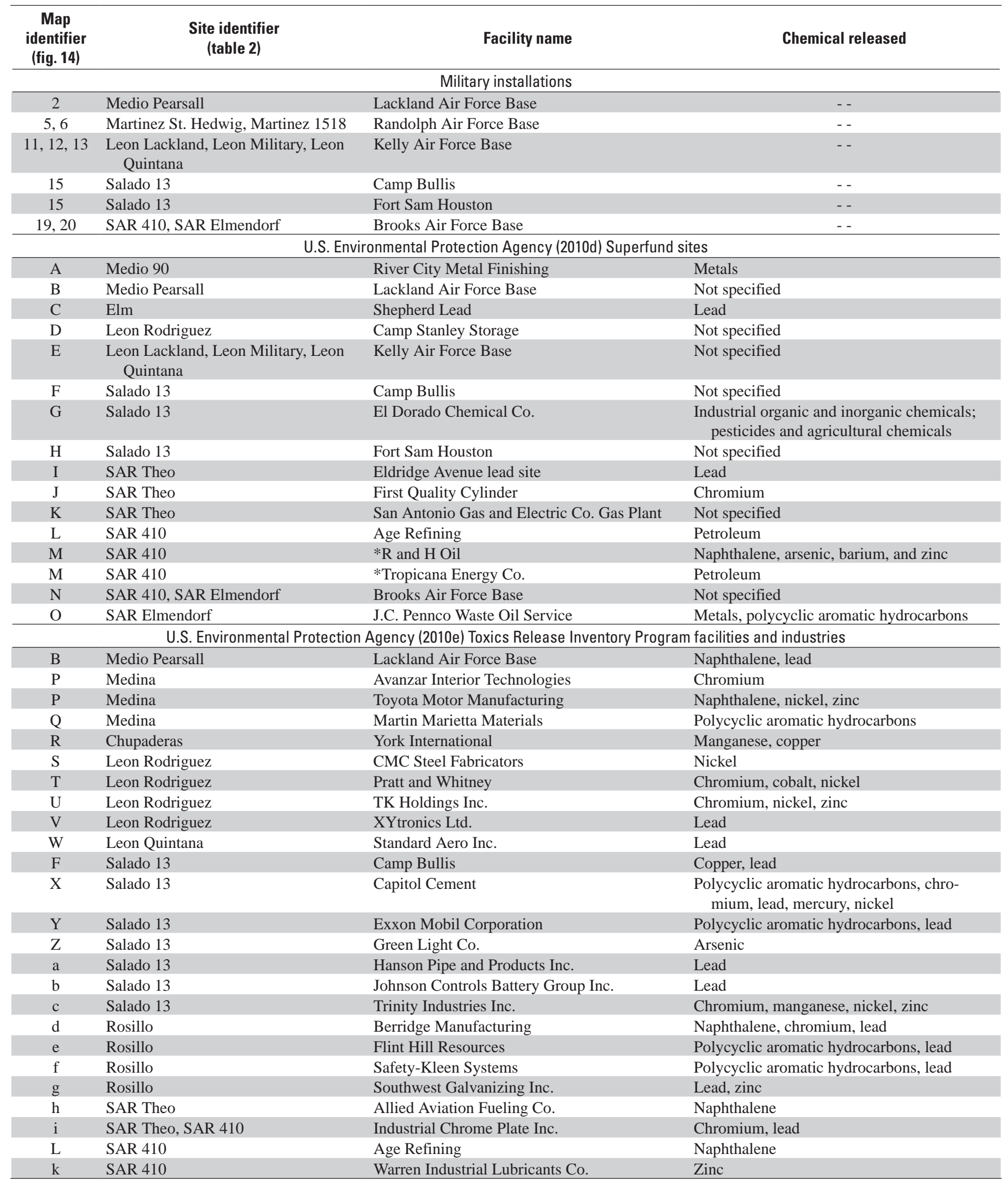

* On National Priorities List (Agency for Toxic Substances and Disease Registry, 2007a). 
Table 10. Results of Mann-Whitney $U$ test used to assess differences in contaminant concentrations measured in streambed-sediment samples on the basis of the presence or absence of suspected contaminant sources in selected watersheds of Bexar County, Texas, 2007-09.

$[\mu \mathrm{g} / \mathrm{g}$, micrograms per gram; <, nondetection less than lower reporting limit (silver) or less than interim reporting level (organic compounds); $\mu \mathrm{g} / \mathrm{kg}$, micrograms per kilogram; PCBs, polychlorinated biphenyls; PAHs, polycyclic aromatic hydrocarbons; shaded cells indicate statistically significant tests (p-value less than .05)]

\begin{tabular}{|c|c|c|c|c|c|c|}
\hline \multirow[b]{2}{*}{ Constituent } & \multicolumn{2}{|c|}{ Presence of suspected contaminant sources } & \multicolumn{2}{|c|}{ Absence of suspected contaminant sources } & \multirow[b]{2}{*}{$\mathbf{U}$} & \multirow[b]{2}{*}{ p-value } \\
\hline & $\begin{array}{l}\text { Number of } \\
\text { samples }\end{array}$ & $\begin{array}{c}\text { Median } \\
\text { concentration }\end{array}$ & $\begin{array}{l}\text { Number of } \\
\text { samples }\end{array}$ & $\begin{array}{c}\text { Median } \\
\text { concentration }\end{array}$ & & \\
\hline \multicolumn{7}{|c|}{ Military installations ${ }^{1}$} \\
\hline Arsenic $(\mu \mathrm{g} / \mathrm{g})$ & 16 & 7.0 & 20 & 6.9 & 140.5 & .55 \\
\hline Cadmium $(\mu \mathrm{g} / \mathrm{g})$ & 16 & .34 & 20 & .30 & 137.0 & .47 \\
\hline Chromium $(\mu \mathrm{g} / \mathrm{g})$ & 16 & 55.3 & 20 & 42.8 & 69.0 & .004 \\
\hline Nickel $(\mu \mathrm{g} / \mathrm{g})$ & 16 & 18.8 & 20 & 18.5 & 129.0 & .33 \\
\hline Lead $(\mu \mathrm{g} / \mathrm{g})$ & 16 & 29.8 & 20 & 21.8 & 100.0 & .058 \\
\hline Zinc $(\mu \mathrm{g} / \mathrm{g})$ & 16 & 113 & 20 & 90.3 & 97.0 & .046 \\
\hline Silver $(\mu \mathrm{g} / \mathrm{g})$ & 16 & $<1$ & 20 & $<1$ & 159.0 & .99 \\
\hline Dieldrin $(\mu \mathrm{g} / \mathrm{kg})$ & 15 & $<.1$ & 20 & $<.1$ & 128.5 & .48 \\
\hline Total chlordane ${ }^{2}(\mu \mathrm{g} / \mathrm{kg})$ & 15 & 2.4 & 20 & $<1.0$ & 69.0 & .007 \\
\hline Total PCBs ${ }^{3}(\mu \mathrm{g} / \mathrm{kg})$ & 15 & 4.5 & 20 & $<2.0$ & 71.5 & .009 \\
\hline Total PAHs ${ }^{4}(\mu \mathrm{g} / \mathrm{kg})$ & 15 & 260 & 20 & 165 & 105.0 & .14 \\
\hline \multicolumn{7}{|c|}{ U.S. Environmental Protection Agency (2010d) Superfund sites ${ }^{5}$} \\
\hline Arsenic $(\mu \mathrm{g} / \mathrm{g})$ & 18 & 6.3 & 18 & 7.3 & 125.5 & .25 \\
\hline Cadmium $(\mu \mathrm{g} / \mathrm{g})$ & 18 & .33 & 18 & .32 & 154.0 & .81 \\
\hline Chromium $(\mu \mathrm{g} / \mathrm{g})$ & 18 & 53.0 & 18 & 44.4 & 116.0 & .15 \\
\hline Copper $(\mu \mathrm{g} / \mathrm{g})$ & 18 & 17.2 & 18 & 15.4 & 113.5 & .13 \\
\hline Mercury $(\mu \mathrm{g} / \mathrm{g})$ & 18 & .04 & 18 & .03 & 110.5 & .11 \\
\hline Nickel $(\mu \mathrm{g} / \mathrm{g})$ & 18 & 18.5 & 18 & 18.9 & 162.0 & .99 \\
\hline Lead $(\mu \mathrm{g} / \mathrm{g})$ & 18 & 27.5 & 18 & 23.7 & 125.0 & .25 \\
\hline Zinc $(\mu \mathrm{g} / \mathrm{g})$ & 18 & 108 & 18 & 91.3 & 119.0 & .18 \\
\hline Mercury $(\mu \mathrm{g} / \mathrm{g})$ & 14 & .03 & 22 & .03 & 152.0 & .96 \\
\hline Nickel $(\mu \mathrm{g} / \mathrm{g})$ & 14 & 18.8 & 22 & 18.5 & 135.5 & .56 \\
\hline Lead $(\mu \mathrm{g} / \mathrm{g})$ & 14 & 25.7 & 22 & 25.8 & 148.0 & .86 \\
\hline Zinc $(\mu \mathrm{g} / \mathrm{g})$ & 14 & 98.2 & 22 & 97.8 & 153.5 & 1.00 \\
\hline Silver $(\mu \mathrm{g} / \mathrm{g})$ & 14 & $<1$ & 22 & $<1$ & 119.0 & .26 \\
\hline Total PAHs ${ }^{4}(\mu \mathrm{g} / \mathrm{kg})$ & 14 & 280 & 21 & 200 & 110.0 & .22 \\
\hline
\end{tabular}

${ }^{1}$ Located in Medio Pearsall, Martinez St. Hedwig, Martinez 1518, Leon Lackland, Leon Military, Leon Quintana, Salado 13, SAR 410, and SAR Elmendorf contributing areas (fig. 14; table 9).

${ }^{2}$ Total chlordane is the sum of cis-chlordane, trans-chlordane, cis-nonachlor, trans-nonachlor, and oxychlordane; censored at the highest interim reporting level of the individual compounds in the summation.

${ }^{3}$ Total PCBs is the sum of PCB congeners 49, 52, 70, 101, 110, 118, 138, 146, 149, 151, 170, 174, 177, 180, 183, 187, 194, and 206; censored at the highest interim reporting level of the individual compounds in the summation.

${ }^{4}$ Total PAHs is the sum of acenaphthene, acenaphthylene, anthracene, benz(a)anthracene, benzo(a)pyrene, chrysene, dibenzo(a,h)anthracene, fluoranthene, fluorene, naphthalene, phenanthrene, and pyrene; censored at the highest interim reporting level of the individual compounds in the summation.

${ }^{5}$ Located in Medio 90, Medio Pearsall, Elm, Leon Rodriguez, Leon Lackland, Leon Military, Leon Quintana, Salado 13, SAR Theo, SAR 410, and SAR Elmendorf contributing areas (fig. 14; table 9).

${ }^{6}$ Located in Medio Pearsall, Medina, Chupaderas, Leon Rodriguez, Leon Quintana, Salado 13, Rosillo, SAR Theo, and SAR 410 contributing areas (fig. 14; table 9). 
Table 11. Kendall's tau nonparametric correlation coefficients between population density, land use, or potential sources of contamination (PSOCs) and median streambed-sediment contaminant concentrations in all 20 contributing areas of the sampling sites in Bexar County, Texas, 2007-09.

[PCBs, polychlorinated biphenyls; PAHs, polycyclic aromatic hydrocarbons; shaded cells indicate statistically significant (p-value less than .05) tau correlation coefficients]

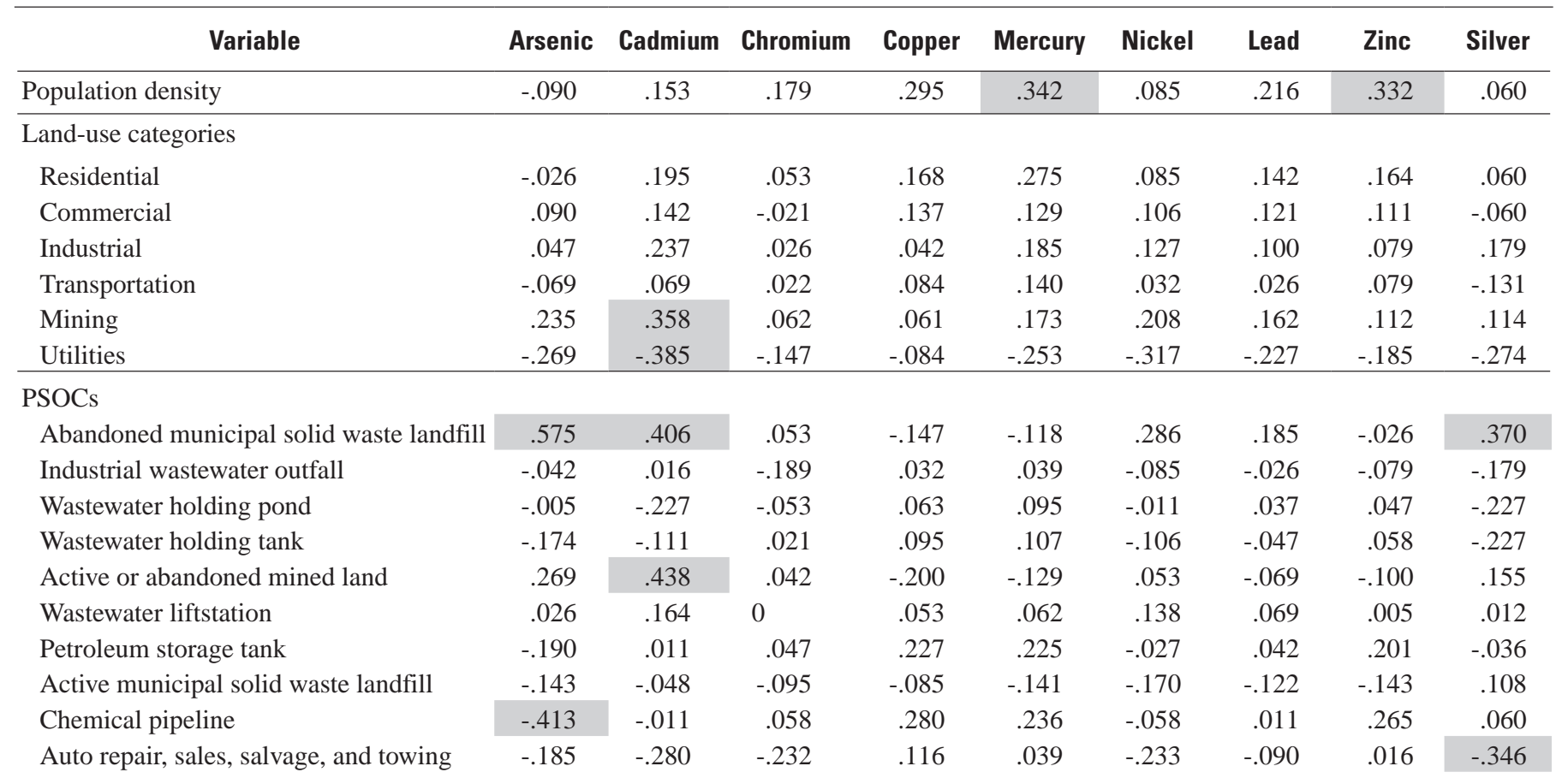

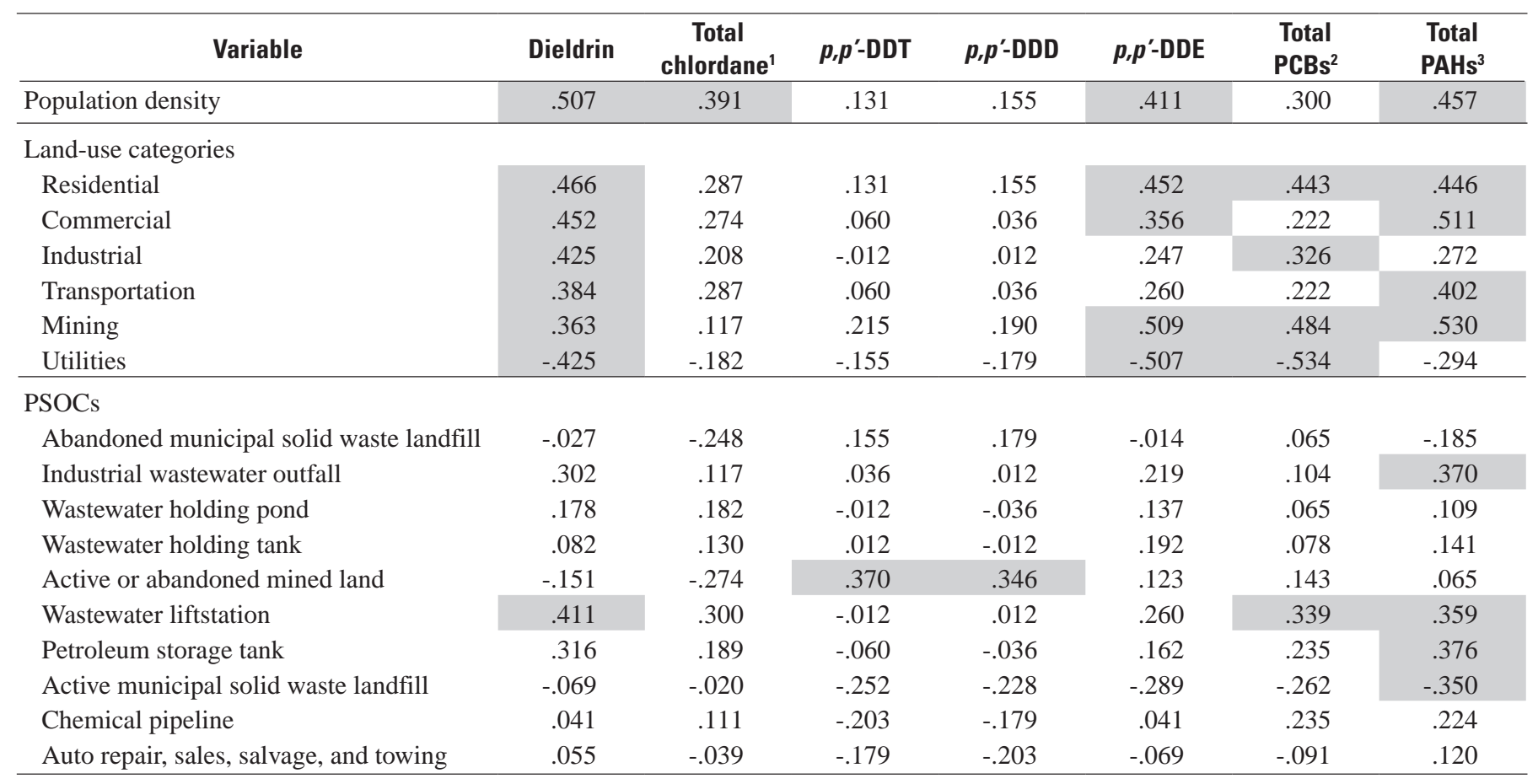

${ }^{1}$ Total chlordane is the sum of cis-chlordane, trans-chlordane, cis-nonachlor, trans-nonachlor, and oxychlordane.

${ }^{2}$ Total PCBs is the sum of PCB congeners 49, 52, 70, 101, 110, 118, 138, 146, 149, 151, 170, 174, 177, 180, 183, 187, 194 , and 206.

${ }^{3}$ Total PAHs is the sum of acenaphthene, acenaphthylene, anthracene, benz(a)anthracene, benzo(a)pyrene, chrysene, dibenzo(a,h)anthracene, fluoranthene, fluorene, naphthalene, phenanthrene, and pyrene. 
and tau values near 0 indicate the variables are unrelated (Helsel and Hirsch, 2002). The concentrations of mercury, zinc, dieldrin, total chlordane, $p, p^{\prime}$-DDE, and total PAHs in streambed-sediment samples were positively correlated with population density. Positive correlations also exist between dieldrin, $p, p^{\prime}$-DDE, and total PAHs and land-use categories (residential and commercial) typical of densely populated areas. Total PAHs also have a statistically significant positive correlation with the transportation land-use category and the industrial wastewater outfall, wastewater liftstation, and petroleum storage tank PSOC categories; and a negative correlation with the active municipal solid waste land-use category. Arsenic concentrations and abandoned municipal solid waste sites had the strongest, positive statistically significant correlation (tau $=.575$ ); cadmium and silver also were positively correlated with abandoned municipal solid waste sites. Statistically significant positive correlations exist between cadmium, dieldrin, $p, p^{\prime}$-DDE, total PCBs, and total PAHs and the mining land-use category and between cadmium, $p, p^{\prime}$-DDT, and $p, p^{\prime}$-DDD concentrations and the PSOC category of active or abandoned mined land. Total PCB concentrations also correlate positively with residential and industrial land-use categories. The strongest, negative correlation $($ tau $=-.534)$ is between total PCB concentrations and the utilities land-use category; cadmium, dieldrin, and $p, p^{\prime}$-DDE also were negatively correlated with the utilities land-use category. The negative correlation between the utilities landuse category and PCBs is surprising considering that PCBs were used until the mid-1970s as insulating fluids and coolants in electrical equipment (transformers and capacitors). The contributing areas of the Martinez St. Hedwig and Martinez 1518 sites have the highest percentages of utilities land use, 0.42 and 0.56 percent, respectively, and very low concentrations or nondetected concentrations of PCB congeners in the samples. One possible explanation for the negative correlation of PCBs and utilities in the Martinez Creek watershed is that the utilities might have been constructed in the watershed after the use of PCBs was halted. Chromium, which exceeded the SQGs more than any other constituent, copper, nickel, and lead do not correlate with any of the available land-use or PSOC categories.

\section{Indicators of Selected Organic Contaminant Sources}

PCB sources were explored by comparing the relative distributions of PCB congeners in the streambed-sediment samples. Patterns of PCB concentrations can be indicative of different PCB sources (Colman, 2000; Johnson and others, 2000; Cacela and others, 2002). PCB congener distribution patterns were determined by normalizing individual congener concentrations; normalization was done by dividing individual $\mathrm{PCB}$ congener concentrations by the sum of PCB congener concentrations for the 13 different PCB congeners with sufficient data (fig. 15). Because of limited use for comparison, samples in which fewer than 50 percent of the analyzed congeners were detected were excluded. Furthermore, PCB congeners not detected more than 50 percent of the time in the selected samples were excluded. This censoring excluded 15 of the 35 streambed-sediment samples and 5 of the 18 PCB congeners. Nondetected concentrations were not included in plots of the PCB congener distribution patterns to avoid creating false or misleading patterns by substituting zeroes or estimated values in place of the nondetected concentrations. Removing the nondetected concentrations resulted in discontinuous profiles for several of the samples.

The normalized PCB congeners were grouped by watershed and plotted for visual comparison of the congener patterns (fig. 15). The dominant congeners in the samples collected from sites in the Leon Creek, Salado Creek, and San Antonio River watersheds are PCB congeners 138, 180, and 187. With a few exceptions, the PCB congener patterns for the samples collected from these three watersheds are similar to one another. The similar PCB congener pattern suggests similar PCB sources in the three watersheds. One possible exception is the sample collected from the Leon Lackland site on December 3, 2007, with a total PCB concentration $(77 \mu \mathrm{g} / \mathrm{kg}$ ) higher than in all other samples in this study. The ratios of the individual $\mathrm{PCB}$ congener concentrations to the total PCB concentration for this sample is markedly different relative to other samples (lower, less variable ratios for PCB congeners 151 through 206); this difference in congener patterns might indicate a different source of PCBs at the Leon Lackland site compared to the other samples collected from Leon Creek, Salado Creek, or the San Antonio River. However, this is just one sample and the relatively anomalous PCB congener pattern was not corroborated by subsequent sampling along the same reach of Leon Creek. Additional information, such as PCB congener analyses of sediment or soil samples from contaminated areas in zones 1 and 2 at the former Kelly AFB plus the collection of a larger number of samples from the Leon Lackland site and other sites near the former Kelly AFB would be needed to make more definitive conclusions about the sources of PCBs measured in samples collected from the Leon Lackland site. The data are insufficient to make any conclusions about PCB sources to the sites in the Medio Creek watershed.

The PAH results were compared to common PAH sources documented in the literature (Van Metre and Mahler, 2010). Common PAH sources such as coal combustion (power plants), automobile-related sources, and coal-tar parking lot sealcoat were compared to PAH ratios measured in Bexar County streambed- and suspended-sediment samples with a chemical mass balance (CBM) source-receptor model. Source-receptor modeling uses an iterative process to attempt to quantify contributions of different sources to a receptor. The CMB source-receptor model is supported by the U.S. Environmental Protection Agency (2008) and requires source profiles (proportional concentrations of PAHs) and receptor data (PAH concentrations for streambed and suspended sediment). Van Metre and Mahler (2010, p. 336) summarized the 


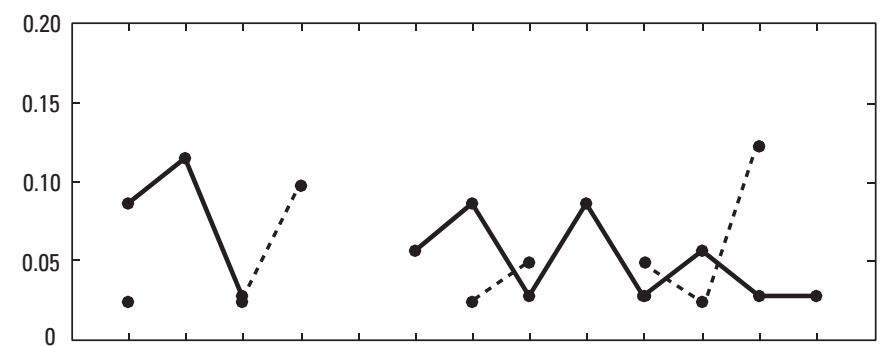

EXPLANATION

$\longrightarrow$ Medio 90; February 27, 2008

- - •- - Medio Pearsall; February 27, 2008

Site identifiers listed in table 2

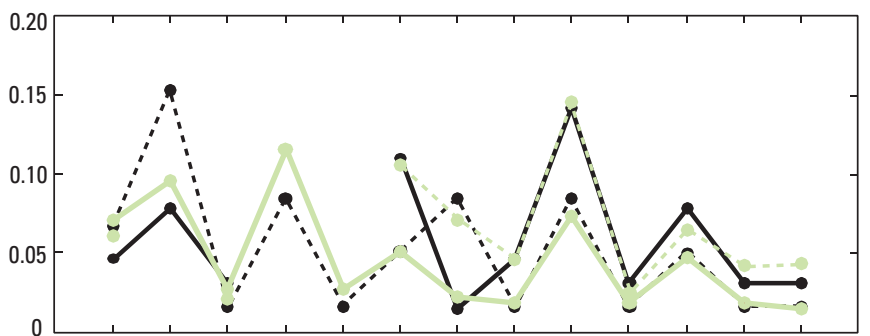

EXPLANATION

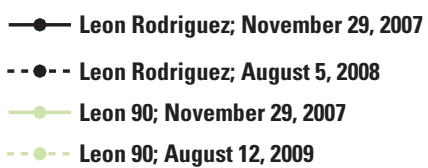

- - - Leon 90; August 12, 2009

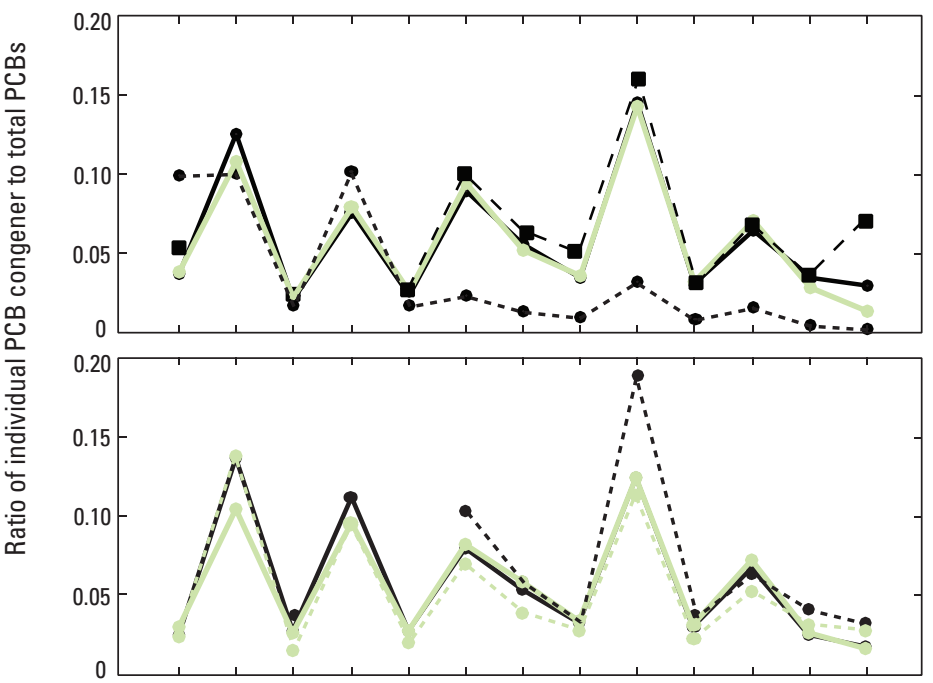

EXPLANATION
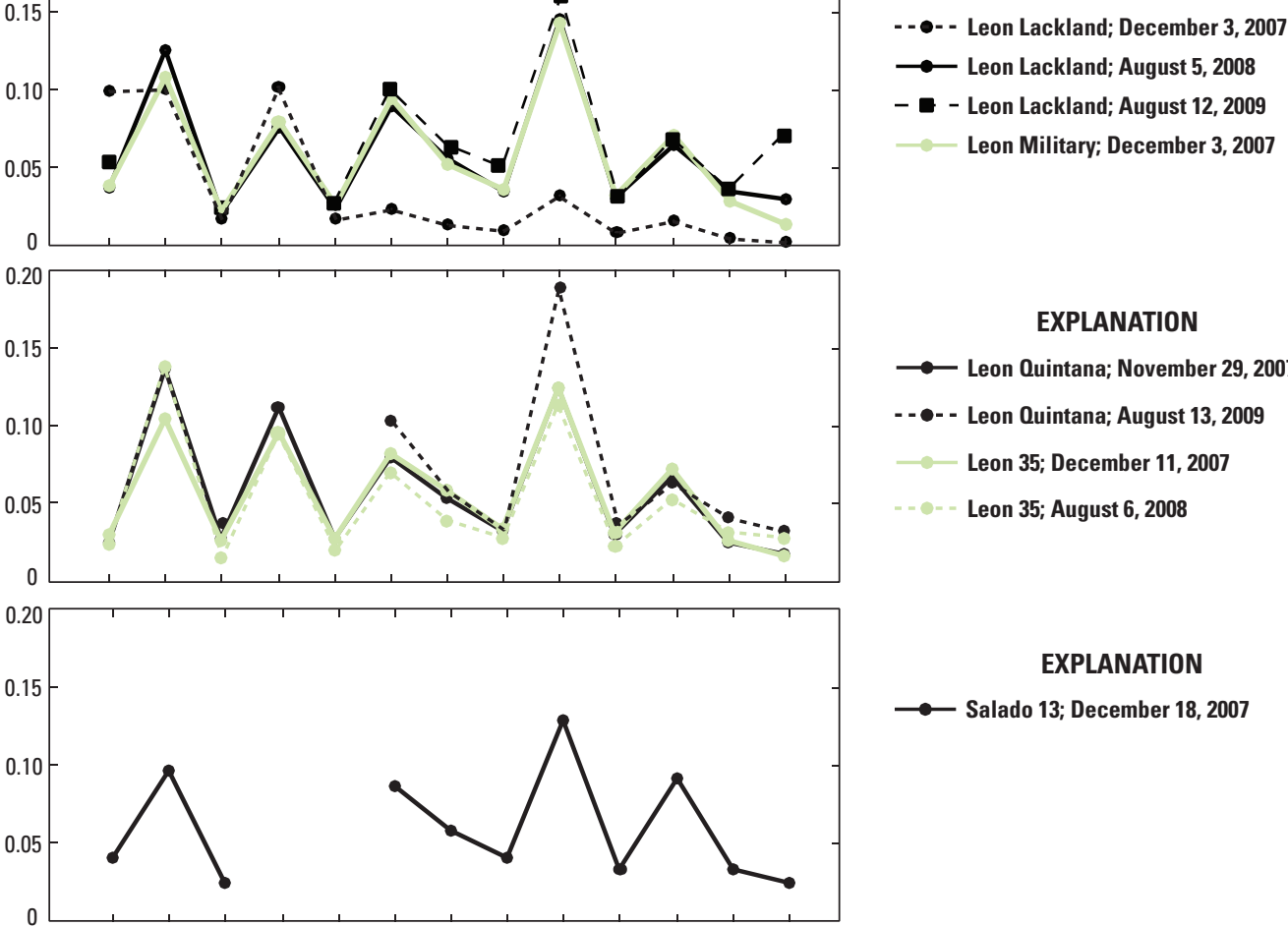

EXPLANATION

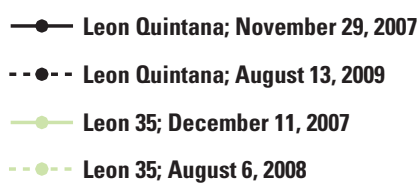

\section{EXPLANATION}

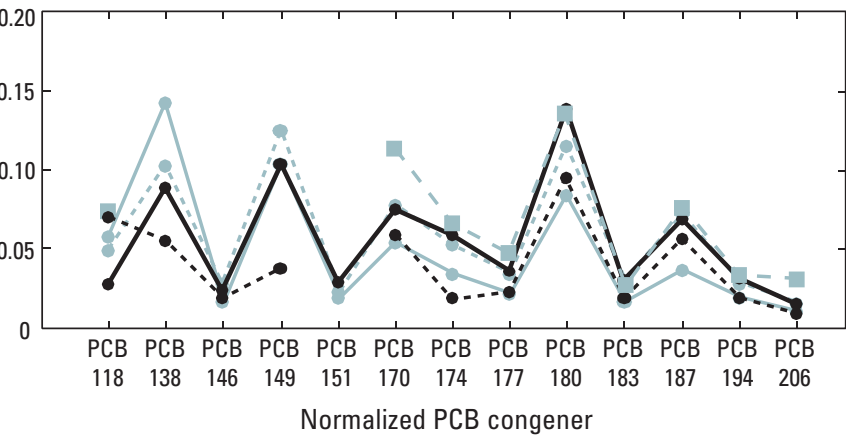

\section{EXPLANATION}

$\rightarrow$ SAR Theo; February 25, 2008

- - ๑ - SAR 410; December 18, 2007

— SAR 410; August 6, 2008

- - SAR 410; August 13, 2009

$\longrightarrow$ - SAR Elmendorf; December 11, 2007

Figure 15. Concentrations of detected polychlorinated biphenyl (PCB) congeners normalized to concentrations of total PCBs in streambed-sediment samples collected from selected sites in Bexar County, Texas, 2007-09. 
assumptions of the model: (1) the composition of each source emission is consistent over the period represented by receptor data, (2) chemical species do not react with each other or with the environment, (3) all sources that contribute significantly to the receptor have been identified and their chemical profile is known, (4) the composition of each source is linearly independent of other sources, and (5) measurement uncertainties are random, uncorrelated, and normally distributed ( $\mathrm{Li}$ and others, 2003).

Van Metre and Mahler (2010, p. 337, table 1) compiled PAH source profiles documented in the literature to compare to bottom sediments deposited post-1990 in lakes across the United States. They normalized the concentrations of 12 selected PAH compounds (phenanthrene, anthracene, fluoranthene, pyrene, benz(a)anthracene, chrysene, benzo(b) fluoranthene, benzo(k)fluoranthene, benzo(e)pyrene, benzo(a) pyrene, indenopyrene, and benzo(g,h,i)perylene) to the sum of the 12 compounds to describe the variability of the PAH mixtures. The same 12 PAHs described by Van Metre and Mahler (2010) were normalized by their sum for the nine streambed-sediment and LVSS samples collected from the Leon Rodriguez, Leon Lackland, Leon Quintana, SAR Theo, and SAR 410 sites with detected concentrations of all 12 selected PAH compounds (appendix 1.3) to compute an average PAH profile for Bexar County sediment (hereinafter, average Bexar County sediment) which was compared graphically to the common PAH sources documented in the literature to determine which sources should be used in the CMB receptor model (fig. 16). Using $\mathrm{PAH}$ data from the nine samples collected during 2007-09 in Bexar County, PAH concentrations were normalized by dividing the individual PAH concentration by the sum of PAH concentration for each of the 12 PAHs with sufficient data. An overall average ratio profile for Bexar County sediment samples was computed by using samples with detected concentrations of all 12 PAH compounds; this prevented nondetected concentrations from distorting the ratio profiles. Seven streambedsediment samples and two LVSS samples had detected concentrations for all 12 PAH compounds. Streambed-sediment samples used in the PAH analysis were collected from the Leon Rodriguez site on November 29, 2007; Leon Lackland site on December 3, 2007, and August 5, 2008; Leon Quintana site on November 29, 2007; SAR Theo site on February 25, 2008; and SAR 410 site on December 18, 2007, and August 6,2008 . The LVSS samples used in the PAH analysis were collected from the SAR 410 site on July 7, 2008, and July 24, 2008. The PAH profile of the average Bexar County sediment sample indicates low concentrations of anthracene, benz(a)anthracene, benzo(k)fluoranthene, indenopyrene, and benzo(g,h,i)perylene and high concentrations of fluoranthene, pyrene, and benzo(b)fluoranthene relative to the overall PAH mixture.
A graphical comparison of the PAH source profiles and average Bexar County sediment PAH profiles and the consideration of possible PAH sources in Bexar County guided the choice of model inputs. Evaluation of the model results was based on model performance measures of chi-squared $\left(\chi^{2}\right)$ and $\mathrm{R}$-square $\left(\mathrm{R}^{2}\right)$. The similarity between source and sediment profiles was evaluated quantitatively with the $\chi^{2}$ value-the lower the $\chi^{2}$, the more similar the two profiles. The $\mathrm{R}^{2}$ was determined by a linear regression of measured to modelcalculated PAH values - an $\mathrm{R}^{2}$ close to 1.0 was desirable. An uncertainty of 40 percent was used for all source profiles $(\mathrm{Li}$ and others, 2003) and of 20 percent for all receptor profiles estimated using the average relative percent difference for a large group of duplicate samples analyzed with the same laboratory methods (Van Metre and Mahler, 2010). The CMB model was run 15 times using multiple combinations of source profiles with all 12 PAHs.

Results of the CMB model indicate that parking lot coaltar sealcoat dust is the largest PAH source to the average Bexar County sediment ( 70.2 to 78.9 percent; table 12 ). The source profile of parking lot coal-tar sealcoat dust used in the model is the average of dust swept from coal-tar sealcoated parking lots from six cities in the United States: Minneapolis, Minn., Chicago, Ill., Detroit, Mich., Washington, D.C., New Haven, Conn., and Austin, Tex. (Mahler and others, 2005; Van Metre and others, 2009). The next largest contributors of PAHs, in order of average fractional loading, are automobile emissions measured in tunnels, emissions from diesel-powered automobiles, emissions from gasoline-powered automobiles, emissions from coal-fired power plants, and used automobile motor oil. Automobile tire particles do not appreciably contribute to PAHs in the average Bexar County sediment on the basis of CMB model results. Overlap exists between the automobile emissions measured in tunnels, emissions from dieselpowered automobiles, and emissions from gasoline-powered automobiles. Measurements of air pollutants in tunnels can be used to quantify on-road traffic emissions (El-Fadel and Hashisho, 2001). Automobile emissions measured in tunnels are a combination of emissions from all types of automobiles passing through the tunnel, whereas emissions from diesel- or gasoline-powered automobiles are specific to automobiles using one type of fuel. Coal combustion activities are present in southern Bexar County, for example the power generating complex on Calaveras Lake (fig. 1) includes the J.K. Spruce, J.T. Deely, and O.W. Sommers power plants. Atmospheric deposition of PAHs from the emissions from these plants is possible - annual wind rose diagrams indicate the wind direction is predominately from the south (Texas Commission on Environmental Quality, 2009b). The results of the CMB model appear reasonable considering the presence of these sources in the Bexar County area and considering that these findings are consistent with the findings of Van Metre and Mahler (2010). 

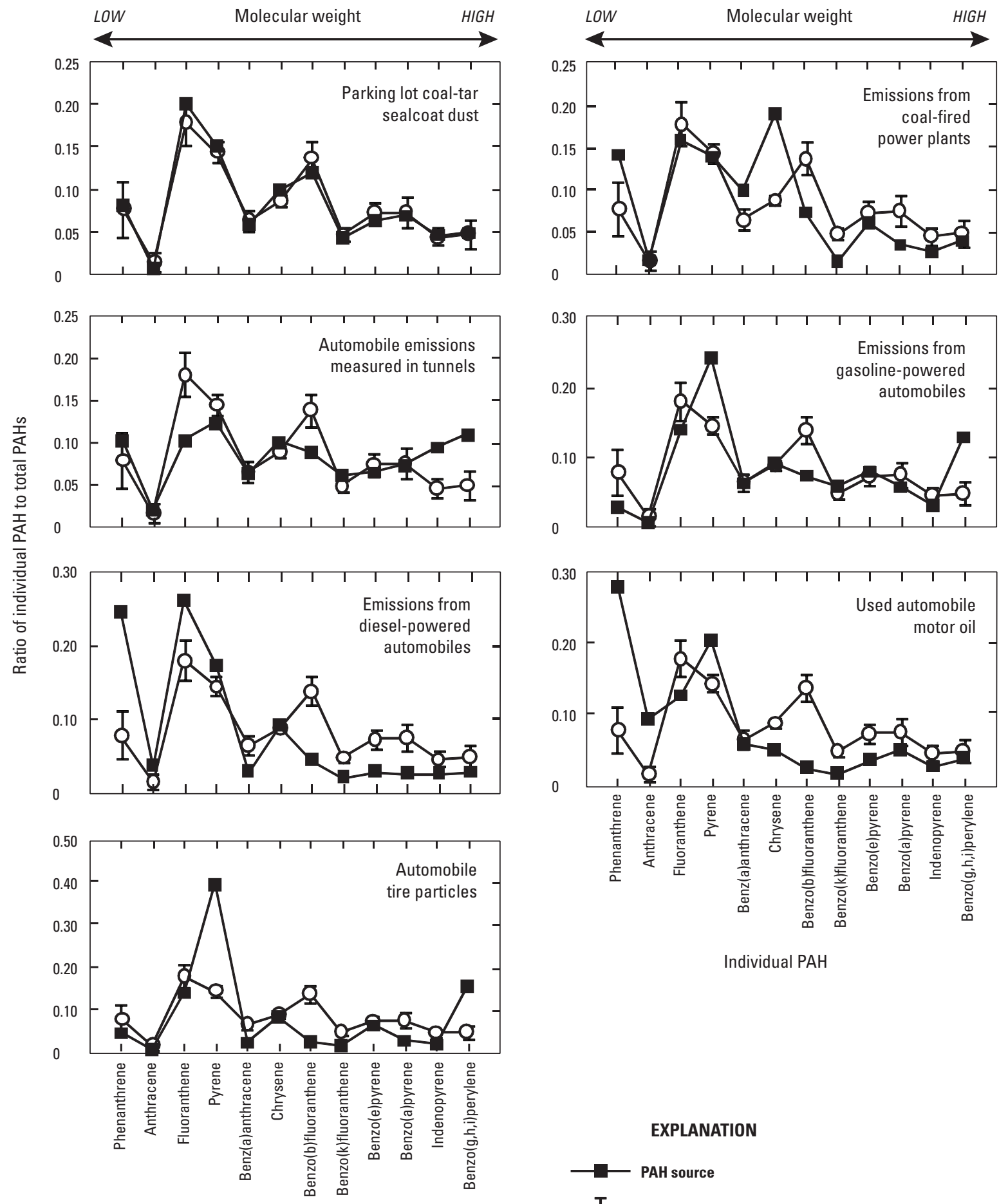

Individual PAH

Individual PAH

\section{EXPLANATION}

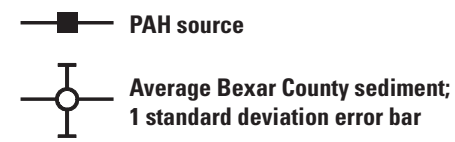

Figure 16. Comparison of polycyclic aromatic hydrocarbon (PAH) profiles for various PAH sources summarized in Van Metre and Mahler (2010, table 1, p. 337) to PAH profile for average Bexar County sediment computed from samples from selected sites in Bexar County, Texas, 2007-09. 
Table 12. Chemical mass balance model results and average fractional loading of total polycyclic aromatic hydrocarbons by source category for sampling sites in Bexar County, Texas, 2007-09.

$[--$, source not included in model $]$

\begin{tabular}{|c|c|c|c|c|c|c|c|c|c|c|}
\hline \multicolumn{4}{|c|}{$\begin{array}{c}\text { Chemical mass balance model } \\
\text { performance categories }\end{array}$} & \multicolumn{7}{|c|}{ Polycyclic aromatic hydrocarbon source categories } \\
\hline Model & $\chi^{2}$ & $\mathbf{R}^{2}$ & $\begin{array}{l}\text { Percent } \\
\text { mass }\end{array}$ & $\begin{array}{l}\text { Parking } \\
\text { lot coal-tar } \\
\text { sealcoat } \\
\text { dust }\end{array}$ & $\begin{array}{c}\text { Emissions } \\
\text { from } \\
\text { coal-fired } \\
\text { power } \\
\text { plants }\end{array}$ & $\begin{array}{c}\text { Auto- } \\
\text { mobile } \\
\text { emissions } \\
\text { measured } \\
\text { in tunnels }\end{array}$ & $\begin{array}{l}\text { Emissions } \\
\text { from } \\
\text { gasoline- } \\
\text { powered } \\
\text { automobiles }\end{array}$ & $\begin{array}{l}\text { Emissions } \\
\text { from diesel- } \\
\text { powered } \\
\text { automobiles }\end{array}$ & $\begin{array}{c}\text { Used } \\
\text { automobile } \\
\text { motor oil }\end{array}$ & $\begin{array}{c}\text { Automobile } \\
\text { tire } \\
\text { particles }\end{array}$ \\
\hline 5 & .45 & .95 & 102.1 & 73.2 & -- & -- & 10.0 & 16.8 & -- & 0 \\
\hline 6 & .49 & .94 & 99.5 & 70.9 & 14.5 & 14.6 & -- & -- & -- & -- \\
\hline 7 & .47 & .95 & 101.9 & 71.3 & 3.5 & -- & 10.0 & 15.2 & -- & -- \\
\hline 9 & .33 & .97 & 99.1 & 76.3 & 4.1 & -- & 9.8 & 4.4 & 5.3 & -- \\
\hline
\end{tabular}

\section{Summary}

The U.S. Geological Survey (USGS), in cooperation with the San Antonio River Authority and the San Antonio Metropolitan Health District Public Center for Environmental Health, completed a reconnaissance-level assessment of the contaminants detected in sediment samples collected from selected streams during 2007-09 in Bexar County, Texas. The USGS periodically collected surficial streambed-sediment samples during base flow and suspended-sediment (largevolume suspended-sediment) samples from selected streams during periods of stormwater runoff. All samples were analyzed for major and trace elements. All samples also were analyzed for organic compounds, including halogenated organic compounds (pesticides [for example, chlordane, dieldrin, DDT, DDD, and DDE]; polychlorinated biphenyls [PCBs]; and brominated flame retardants), semivolatile organic compounds (SVOCs), and polycyclic aromatic hydrocarbons (PAHs).

Elevated concentrations of sediment-associated contaminants are typically associated with urban areas; San Antonio in Bexar County is a large urban area and currently (2010) the seventh most populous city in the United States. Previous sediment sampling in Bexar County water bodies documented high concentrations of several trace elements and organic contaminants that are of concern to aquatic life and human health. This report describes an assessment of selected sediment-associated contaminants in the cumulative drainage areas (watersheds) of sampling sites on eight streams in the Bexar County area: Medio Creek, Medina River, Elm Creek, Martinez Creek, Chupaderas Creek, Leon Creek, Salado
Creek, and San Antonio River. Selected contaminants were assessed by using a variety of methods-observations of occurrence and distribution, comparison to sediment-quality guidelines and data from previous studies, statistical analyses, and source indicators.

The amount of urban development differs in the Bexar County part of the watersheds for each of these eight streams. Urban development is greater in the Leon Creek, Salado Creek, and San Antonio River watersheds compared to that in the Medio Creek, Medina River, Elm Creek, Martinez Creek, and Chupaderas Creek watersheds. Streambed- and suspended-sediment samples were collected more frequently from sites in the more developed watersheds than from sites in the less developed watersheds.

Generally, concentrations of trace elements in the samples from this study were low compared to two consensus-based sediment-quality guidelines - the threshold effect concentration (TEC), or lower level, and the probable effect concentration (PEC), or higher level. Trace element concentrations were greater than the PEC in 1.5 percent of the samples and greater than the TEC in 28 percent of the samples. The highest arsenic concentrations were in streambed-sediment samples collected from USGS station 08182410 Chupaderas Creek at State Road 106 near San Antonio, Tex. (hereinafter, Chupaderas site) (22.2 micrograms per gram $[\mu / \mathrm{g}]$ ), USGS station 08181445 Leon Creek at State Highway 90, San Antonio, Tex. (12.8 $\mu \mathrm{g} / \mathrm{g})$, and USGS station 292338098360501 Leon Creek at Morey Road, San Antonio, Tex. (hereinafter, Leon Morey site) $(12.2 \mu \mathrm{g} / \mathrm{g})$. Arsenic concentrations exceeded the TEC in 12 percent of the samples. Kruskal-Wallis and Tukey's multiple comparison test results indicate streambed-sediment 
samples from Leon Creek had significantly higher arsenic concentrations compared to the San Antonio River streambedsediment samples. Arsenic concentrations in streambed-sediment samples and abandoned municipal solid waste sites had a statistically significant correlation (tau $=.575)$.

Cadmium concentrations were highest in samples from USGS station 292029098351400 Leon Creek at Quintana Road, San Antonio, Tex. (hereinafter, Leon Quintana site) (streambed sediments 6.5 and $5.4 \mu \mathrm{g} / \mathrm{g}$ ) and USGS station 08181480 Leon Creek at Interstate Highway 35, San Antonio, Tex. (hereinafter, Leon 35 site) (suspended sediment $4.4 \mu \mathrm{g} / \mathrm{g}$ and streambed sediment $4.1 \mu \mathrm{g} / \mathrm{g}$ ). Concentrations exceeded the PEC in the two streambed-sediment samples from the Leon Quintana site and exceeded the TEC in 16 percent of samples from all sites. On the basis of results of KruskalWallis and Tukey's multiple comparison tests, cadmium concentrations were significantly higher in streambed-sediment samples from Leon Creek compared to streambed-sediment samples from Salado Creek and San Antonio River. A statistically significant, positive correlation exists between cadmium concentrations in streambed-sediment samples and mining land-use and between cadmium concentrations and the potential source of contamination categories of active or abandoned mined land and abandoned municipal solid waste landfill listed by the Texas Commission on Environmental Quality for the Source Water Assessment Program.

The PEC for chromium concentrations was exceeded in four samples, the two streambed-sediment samples from the Leon Quintana site and one streambed-sediment sample and one suspended-sediment sample from the Leon 35 site. Chromium concentrations exceeded the TEC in 69 percent of the samples and exceeded the sediment-quality guideline more frequently than concentrations of any other constituent analyzed in this study. Chromium concentrations in streambedsediment samples do not correlate with any of the available land-use or potential source of contamination categories.

Lead concentrations were highest in the samples from the Leon 35 site (streambed sediment $69.3 \mu \mathrm{g} / \mathrm{g}$ ), USGS station 08178565 San Antonio River at Loop 410, San Antonio, Tex. (hereinafter, SAR 410 site) (suspended sediment $68.2 \mu \mathrm{g} / \mathrm{g}$ ), and Leon Quintana site (streambed sediment $65.0 \mu \mathrm{g} / \mathrm{g}$ ). Lead concentrations exceeded the TEC in 33 percent of the samples; only chromium concentrations exceeded the sediment-quality guideline more frequently.

Mercury concentrations were highest in two streambedsediments samples from the Leon Quintana site $(0.09$ and 0.08 $\mu \mathrm{g} / \mathrm{g}$ ), one suspended-sediment sample from USGS station 08181800 San Antonio River near Elmendorf, Tex. (hereinafter, SAR Elmendorf site) $(0.07 \mu \mathrm{g} / \mathrm{g})$, and two suspended-sediment samples from the Leon 35 site $(0.07 \mu \mathrm{g} / \mathrm{g})$. No mercury concentrations were greater than the TEC.

Mean trace element concentrations in suspendedsediment samples collected in Bexar County during 2007-09 generally were lower compared to mean concentrations in samples collected from the Austin and Fort Worth, Tex., areas during previous studies. However, considering the relatively large ranges and standard deviations associated with the concentrations measured in all three areas, the trace element concentrations are similar.

On the basis of Mann-Whitney U test results, the presence of a military installation in a watershed was associated with statistically significant higher concentrations of chromium, mercury, and zinc in streambed sediments compared to the concentrations of the same elements in a watershed without a military installation.

At least three or more halogenated organic compounds were detected in each sediment sample collected during 2007-09 and 66 percent of the concentrations were less than the respective interim reporting levels (nondetections). Halogenated organic compound concentrations generally were low compared to consensus-based sediment-quality guidelines-TECs were exceeded in 11 percent of the analyses and PECs were exceeded by DDT, DDD, and DDE concentrations in one sample.

Chlordane compounds were the most frequently detected halogenated organic compounds with one or more detections (concentrations equal to or greater than interim reporting levels) of chlordane compounds in every watershed. In this report, total chlordane is defined as the sum of cischlordane, trans-chlordane, cis-nonachlor, trans-nonachlor, and oxychlordane. The highest total chlordane concentrations were in a streambed-sediment sample from USGS station 292240098353600 Leon Creek at Lackland Air Force Base Golf Course, San Antonio, Tex. (hereinafter, Leon Lackland site) (11 micrograms per kilogram $[\mu \mathrm{g} / \mathrm{kg}])$ and in a suspended-sediment sample from the SAR 410 site $(6.7 \mu \mathrm{g} /$ $\mathrm{kg}$ ). Chlordane compounds were detected in 94 percent of the samples; 6 percent of the analyses had concentrations of cis-chlordane plus trans-chlordane greater than the TEC. The results of the Mann-Whitney $\mathrm{U}$ test indicate that the presence of a military installation in a watershed was associated with statistically significant higher total chlordane concentrations.

Dieldrin was detected in 50 percent of all samples but not detected in any samples from USGS station 08185095 Martinez Creek at Farm Road 1518 near St. Hedwig, Tex. (hereinafter, Martinez 1518 site), Chupaderas, or Leon Morey sites. Dieldrin concentrations were highest in a streambedsediment sample from USGS station 292443098364600 Leon Creek at Rodriguez Park, San Antonio, Tex. (hereinafter, Leon Rodriguez site) $(1.1 \mu \mathrm{g} / \mathrm{kg})$ and a suspended-sediment sample from the SAR $410(0.84 \mu \mathrm{g} / \mathrm{kg})$. All dieldrin concentrations were less than the TEC of $1.90 \mu \mathrm{g} / \mathrm{kg}$. Dieldrin concentrations in streambed-sediment samples correlate positively with population density and land-use categories (residential and commercial) typical of densely populated areas.

The DDT compounds ( $p, p^{\prime}$-DDT, $p, p^{\prime}$-DDD, and $p, p^{\prime}$ DDE) were detected most frequently at sites in the Leon Creek and San Antonio River watersheds. The highest concentrations of all three DDT compounds were in a streambed-sediment sample from Leon Lackland (110 $\mu \mathrm{g} / \mathrm{kg}$ of $p, p^{\prime}$-DDT, 55 $\mu \mathrm{g} / \mathrm{kg}$ of $p, p^{\prime}-\mathrm{DDD}$, and $41 \mu \mathrm{g} / \mathrm{kg}$ of $p, p^{\prime}$-DDE). The DDT compounds were detected less frequently than some other 
halogenated organic compounds, however most detections exceeded the TECs. The compound $p, p^{\prime}$-DDT was detected in 13 percent of the samples with 67 percent of those detections exceeding the TEC. The compounds $p, p^{\prime}$-DDD and $p, p^{\prime}-\mathrm{DDE}$ were detected in 19 and 35 percent of the samples with 78 and 53 percent of those detections exceeding the TECs, respectively. The results of the Mann-Whitney $U$ test indicate that the presence of a military installation in a watershed was associated with statistically significant higher $p, p^{\prime}$-DDE concentrations. $p, p^{\prime}$-DDE concentrations in streambed-sediment samples correlate positively with population density and and land-use categories (residential and commercial) typical of densely populated areas.

One or more PCB congeners were detected in 90 percent of the sediment samples collected from all sites. The fewest detections were in samples from the Martinez St. Hedwig and Chupaderas sites, whereas the most detections were in samples from the Leon Lackland, Leon 35, and SAR 410 sites. In most watersheds, the larger congeners (PCBs 118 to 206) were detected more frequently compared to the smaller congeners (PCBs 49 to 110). The highest concentrations of total PCBs (sum of the 18 reported congeners) were in a streambedsediment sample from Leon Lackland $(77 \mu \mathrm{g} / \mathrm{kg})$ and a suspended-sediment sample from Leon 35 (suspended sediment $26 \mu \mathrm{g} / \mathrm{kg}$ ). Total PCB concentrations were significantly higher in the streambed-sediment samples from the San Antonio River compared to the streambed-sediment samples from Salado Creek, on the basis of the results of KruskalWallis and Tukey's multiple comparison tests. The results of the Mann-Whitney U test indicate that the presence of a military installation in a watershed was associated with statistically significant higher total PCB concentrations. Additionally, the total PCB concentrations in streambed-sediment samples correlated positively with residential, industrial, and mining land uses. The PCB mixtures in samples from Leon Creek, Salado Creek, and the San Antonio River are dominated by PCB congeners 138, 180, and 187 on the basis of visual examination of the patterns of the ratios of individual PCB congeners to total PCBs. The similar PCB congener patterns suggest similar PCB sources in the three watersheds.

Brominated flame retardant compounds were not detected in samples from the Chupaderas site or USGS station 08180840 Elm Creek at State Highway 16, San Antonio, Tex. The most frequent detections occurred in the samples from sites in the Medio Creek, Leon Creek, and San Antonio River watersheds. The highest concentrations of the four most frequently detected brominated flame retardants, polybrominated diphenyl ethers (PBDEs) 100, 153, 154, and dechlorane plus, were in samples from the Medio 90, Leon 35, Salado Southton, SAR 410, and SAR Elmendorf sites. No sedimentquality guidelines exist for the brominated flame retardant compounds for comparison.

Mean halogenated organic compound concentrations in suspended-sediment samples collected from sites in Bexar County during 2007-09 generally were lower compared to mean concentrations in samples from the Austin and Fort
Worth areas. However, considering the relatively large ranges and standard deviations associated with the concentrations measured in all three areas, the halogenated organic compound concentrations are similar.

PAHs were detected most frequently in samples from sites in the Leon Creek and San Antonio River watersheds. PAHs were not detected often and only at relatively low concentrations in samples from the Medio Creek, Medina River, Elm Creek, Martinez Creek, and Chupaderas Creek watersheds. In this report, total PAH is the sum of 12 compounds: acenaphthene, acenaphthylene, anthracene, benz(a)anthracene, benzo(a)-pyrene, chrysene, dibenz(a,h)anthracene, fluoranthene, fluorene, naphthalene, phenanthrene, and pyrene. The greatest total PAH concentrations were in a streambedsediment sample from Leon Rodriguez $(4,000 \mu \mathrm{g} / \mathrm{kg})$ and in a suspended-sediment sample from SAR $410(3,600 \mu \mathrm{g} / \mathrm{kg})$. Total PAH concentrations exceeded the TEC in 14 percent of the samples, and none of the total PAH concentrations exceeded the PEC. Total PAH concentrations in streambedsediment samples correlate positively with population density; residential, commercial, transportation, and mining land-use categories; and industrial wastewater outfall, wastewater liftstation, and petroleum storage tank potential source of contamination categories. Mean total PAH concentrations in suspended-sediment samples collected in Bexar County during 2007-09 were generally lower, but similar overall when considering the large ranges and standard deviations, compared to mean total PAH concentrations measured during similar, previous studies in the Austin and Fort Worth areas.

The overall degree of sediment contamination of the Bexar County sampling sites was assessed by using the mean PEC quotient. The mean PEC quotient is derived by using the three groups of constituents for which consensus-based SQGs exist - trace elements, halogenated organic compounds, and PAHs. To compute the mean PEC quotient, the concentration of each constituent is divided by its respective PEC to get the individual PEC quotient, and then the individual PEC quotients are summed for each sample and divided by the number of PEC quotients to get the mean PEC quotient. Mean PEC quotients provide a basis for predicting sediment toxicity-a mean PEC quotient greater than 0.5 is a reasonable indicator of whether the sediment is toxic to benthic biota and correctly predicts toxicity in 85 percent of samples tested. Moreover, the incidence of toxicity is highly correlated to the mean PEC quotient. The mean PEC quotient is less than 0.5 for all but one of the sediment samples collected from sites in Bexar County during 2007-09. A streambed-sediment sample collected from the Leon Lackland site had a mean PEC quotient of 0.51. The next highest mean PEC quotients were measured in samples from the Leon Quintana, Leon 35, Leon Military, and SAR 410 sites (in order of decreasing values).

PAH sources were investigated by comparing the ratios of individual PAH compounds to total PAH of several common PAH sources such as coal combustion (power plants), automobile-related sources, and coal-tar parking lot sealcoat and the Bexar County streambed- and suspended-sediment samples. 
The contribution from each PAH source was estimated by using a chemical mass balance model, which indicated that parking lot coal-tar sealcoat dust is the largest PAH source to the average Bexar County sediment, accounting for 70.2 to 78.9 percent of the PAHs in the mixture.

\section{References Cited}

Agency for Toxic Substances and Disease Registry, 1994, Toxicological profile for chlordane: U.S. Department of Health and Human Services, accessed January 8, 2010, at http://www.atsdr.cdc.gov/ToxProfiles/tp31.pdf.

Agency for Toxic Substances and Disease Registry, 1998, Health consultation-Groundwater contamination at fire protection training area number 2, U.S. Air Force, Brooks Air Force Base, San Antonio, Bexar County, Texas: U.S. Department of Health and Human Services, accessed January 27, 2010, at http://www.atsdr.cdc.gov/HAC/pha/ PHA.asp $?$ docid $=67 \& p g=0$.

Agency for Toxic Substances and Disease Registry, 2000, Toxicological profile for polychlorinated biphenyls (PCBs): U.S. Department of Health and Human Services, accessed August 2, 2010, at http://www.atsdr.cdc.gov/ToxProfiles/ tp17.pdf.

Agency for Toxic Substances and Disease Registry, 2002, Toxicological profile for DDT, DDE, and DDD: U.S. Department of Health and Human Services, accessed December 30, 2010, at http://www.atsdr.cdc.gov/ ToxProfiles/tp35.pdf.

Agency for Toxic Substances and Disease Registry, 2004, Toxicological profile for polybrominated biphenyls and polybrominated diphenyl ethers: U.S. Department of Health and Human Services, accessed January 3, 2011, at http://www.atsdr.cdc.gov/ToxProfiles/tp68.pdf.

Agency for Toxic Substances and Disease Registry, 2007a, 2007 CERCLA priority list of hazardous substances: U.S. Department of Health and Human Services, accessed January 8, 2010, at http://www.atsdr.cdc.gov/cercla/07list. html.

Agency for Toxic Substances and Disease Registry, 2007b, ToxFAQs for lead: U.S. Department of Health and Human Services, accessed March 3, 2011, at http://www.atsdr.cdc. gov/toxfaqs/TF.asp? id $=93 \&$ tid $=22$.

Alaee, Mehran, Arias, Pedro, Sjödin, Andreas, and Bergman, Åke, 2003, An overview of commercially used brominated flame retardants, their applications, their use patterns in different countries/regions and possible modes of release: Environment International, v. 29, no. 6, p. 683-689.

Alamo Area Council of Governments, 2002, Closed landfill inventory, Bexar County inventory of closed or abandoned landfills-Map R11: accessed July 31, 2008, at http://regmapr.aacog.com/clis_pdf/R11.pdf.

Ballschmiter K., and Zell M., 1980, Analysis of polychlorinated biphenyls (PCB) by glass capillary gas chromatography-Composition of technical Aroclor and clophen-PCB mixtures: Fresenius' Journal of Analytical Chemistry, v. 302, no. 1 , p. 20-31.

Bradford, W.L., and Horowitz, A.J., eds., 1988, The role of sediments in the chemistry of aquatic systems-Proceedings of the Sediment Chemistry Workshop, February 8-12, 1982: U.S. Geological Survey Circular 969, 75 p.

Briggs, P.H., and Meier, A.L., 2002, The determination of forty-two elements in geological materials by inductively coupled plasma-mass spectrometry for NAWQA, Chapter J, in Taggart, J.E., Jr., ed., Analytical methods for chemical analysis of geologic and other materials: U.S. Geological Survey Open-File Report 02-223, p. J1-J14, available at http://pubs.usgs.gov/of/2002/ofr-02-0223/ J22NAWQAMethod_M.pdf.

Brooks Air Force Base, 2000, Hazardous waste management plan: Air Force Materiel Command, 311th Human Systems Wing/Environmental Management, accessed February 11, 2010, at http://www.afcee.lackland.af.mil/eq/programs/ summary.asp? rscID=295.

Brown, D.W., McCain, B.B., Horness, B.H., Sloan, C.A., Tilbury, K.L., Pierce, S.M., Burrows, D.G., Chan, Sin-Lam, Landahl, J.T., and Krahn, M.M., 1998, Status, correlations and temporal trends of chemical contaminants in fish and sediment from selected sites on the Pacific Coast of the USA: Marine Pollution Bulletin, v. 37, nos. 1-2, p. 67-85.

Buchman, M.F., 2008, NOAA screening quick reference tables: Seattle, National Oceanic and Atmospheric Administration, Office of Response and Restoration, Report 08-1, 34 p.

Cacela, Dave, Beltman, D.J., and Lipton, Joshua, 2002, Polychlorinated biphenyl source attribution in Green Bay, Wisconsin, USA, using multivariate similarity among congener profiles in sediment samples: Environmental Toxicology and Chemistry, v. 21, no. 8, p. 1,591-1,599.

CH2M Hill, 1999, January 1999 semiannual compliance plan report (July-December 1998), Part II-Leon Creek semiannual assessment: Prepared for Kelly Air Force Base, San Antonio, Tex., Administrative Record file number 919, 254 p., available at https://afrpaar.lackland.af.mil/ar/getdoc. aspx?file=KELLY_AR_919.pdf.

CH2M Hill, 2001, Tier 2 ecological risk assessment-Volume 1: Prepared for Kelly Air Force Base, San Antonio, Tex., Administrative Record file number 2103, 434 p., available at https://afrpaar.lackland.af.mil/ar/getdoc. aspx?file $=$ KELLY_AR_2103.pdf. 
Chalmers, Ann, 2002, Trace elements and organic compounds in streambed sediment and fish tissue of coastal New England stream, 1998-99: U.S. Geological Survey WaterResources Investigations Report 02-4179, 30 p.

Chalmers, A.T., Van Metre, P.C., and Callender, Edward, 2007, The chemical response of particle-associated contaminants in aquatic sediments to urbanization in New England, U.S.A.: Journal of Contaminant Hydrology, v. 91, nos. 1-2, p. 4-25.

Childress, C.J.O., Foreman, W.T., Connor, B.F., and Maloney, T.J., 1999, New reporting procedures based on long-term method detection levels and some considerations for interpretations of water-quality data provided by the U.S. Geological Survey National Water Quality Laboratory: U.S. Geological Survey Open-File Report 99-193, 19 p.

Chiou, C.T., Peters, L.J., and Freed, V.H., 1979, A physical concept of soil-water equilibria for nonionic compounds: Science, v. 206, p. 831-832.

Clark, G.M., Maret, T.R., Rupert, M.G., Maupin, M.A., Low, W.H., and Ott, D.S., 1998, Water quality in the upper Snake River Basin, Idaho and Wyoming, 1992-95: U.S. Geological Survey Circular 1160, 35 p.

Code of Federal Regulations, 1998, Title 40-Protection of environment, Part 122-Environmental Protection Agency administered permit programs: The National Pollutant Discharge Elimination System, Appendix D-NPDES Permit Application Testing Requirements.

Colman, J.A., 2000, Source identification and fish exposure for polychlorinated biphenyls using congener analysis from passive water samplers in the Millers River Basin, Massachusetts: U.S. Geological Survey Water-Resources Investigations Report 00-4250, 44 p.

Curriero, F.C., Patz, J.A., Rose, J.B., and Lele, Subhash, 2001, The association between extreme precipitation and waterborne disease outbreaks in the United States, 1948-1994: American Journal of Public Health. v. 91, no. 8, 6 p.

Dodder, N.G., Strandberg, B., and Hites, R.A., 2002, Concentrations and spatial variations of polybrominated diphenyl ethers and several organochlorine compounds in fishes from the northeastern United States: Environmental Science and Technology, v. 36, p. 146-151.

Eisenreich, S.J., Baker, J.E., Franz, T., Swanson, M., Rapaport, R.A., Strachan, W.M.J., and Hites, R.A., 1992, Atmospheric deposition of hydrophobic organic contaminants to the Laurentian Great Lakes, in Schnoor, J.L., ed., Fate of pesticides and chemicals in the environment: New York, John Wiley, p. 51-78.

Eisenreich, S.J., Capel, P.D., and Looney, B.B., 1983, PCB dynamics in Lake Superior water, in Mackay, D.,
Paterson, S., Eisenreich, S.J., and Simmons, M., eds., Physical behavior of PCBs in the Great Lakes: Ann Arbor, Mich., Ann Arbor Science, p. 181-211.

El-Fadel, M., and Hashisho, Z., 2001, Vehicular emissions in roadway tunnels-A critical review: Critical Reviews in Environmental Science and Technology, v. 31, p. 125-174.

European Parliament and European Council, 2003, Directive 2002/96/EC of the European Parliament and of the Council of 27 January 2003 on waste electrical and electronic equipment: Official Journal of the European Union, L 037, 13/02/2003, p. 0024-0039.

Garbarino, J.R., Hayes, H.C., Roth, D.A., Antweiler, R.C., Brinton, T.I., and Taylor, H.E., 1995, Heavy metals in the Mississippi River, in Meade, R.H., ed., Contaminants in the Mississippi River, 1987-92: U.S. Geological Survey Circular 1133, p. 53-72.

Ging, P.B., Van Metre, P.C., and Callender, Edward, 1999, Bottom sediments of Lorence Creek Lake, San Antonio, Texas, reflect contaminant trends in an urbanizing watershed: U.S. Geological Survey Fact Sheet FS-149-99, 4 p.

Ginsburg, J.M., 1947, Comparative toxicity of DDT isomers and related compounds to mosquito larvae and fish: Science, v. 105, p. 233-234.

Gschwend, P.M., Chen, P.H., and Hites, R.A., 1983, On the formation of perylene in recent sediments-Kinetic models: Geochimica et Cosmochimica Acta, v. 47, p. 2,115-2,119.

Guy, H., 1969, Laboratory theory and methods for sediment analysis: U.S. Geological Survey Techniques of Water Resources Investigations, book 5, chap. C1, 58 p.

Hageman, P.L., 2007, Determination of mercury in aqueous and geologic materials by continuous flow-cold vapor-atomic fluorescence spectrometry (CVAFS): U.S. Geological Survey Techniques and Methods, book 5, chap. D2, 6 p.

Helsel, D.R., 2005, Nondetects and data analysis: statistics for censored environmental data: Hoboken, N.J., John Wiley, $250 \mathrm{p}$.

Helsel, D.R., 2009, Summing nondetects-Incorporating low-level contaminants in risk assessment: Integrated Environmental Assessment and Management, v. 6, p. 361-366.

Helsel, D.R., and Hirsch, R.M., 2002, Statistical methods in water resources: U.S. Geological Survey Techniques of Water-Resources Investigations, book 4, chap. A3, 510 p., available at http://pubs.usgs.gov/twri/twri4a3/.

Hitch, R.K., and Day, H.R., 1992, Unusual persistence of DDT in some western USA soils: Bulletin of Environmental Contamination and Toxicology, v. 48, p. 259-264. 
Horowitz, A.J., and Elrick, K.A., 1987, The relation of stream sediment surface area, grain size and composition to trace element chemistry: Applied Geochemistry, v. 2, p. 437-451.

Iman, R.L., and Conover, W.J., 1983, A modern approach to statistics: New York, John Wiley, 496 p.

Ingersoll, C.G., MacDonald, D.D., Wang, N., Crane, J.L., Field, L.J., Haverland, P.S., Kemble, N.E., Lingskoog, R.A., Severn C., and Smorong, D.E., 2000, Prediction of sediment toxicity using consensus-based freshwater sediment quality guidelines: U.S. Environmental Protection Agency EPA 905/R-00/007.

Ingersoll, C.G., MacDonald, D.D., Wang, J., Crane, J.L., Field, L.J., Haverland, P.S., Kemble, N.E., Lindskoog, R.A., Severn C., and Smorong, D.E., 2001, Predictions of sediment toxicity using consensus-based freshwater sediment quality guidelines: Archives of Environmental Contamination and Toxicology, v. 41, p. 8-21.

Johnson, G.W., Jarman, W.M., Bacon, C.E., Davis, J.A., Ehrlich, Robert, and Risebrough, R.W., 2000, Resolving polychlorinated biphenyl source fingerprints in suspended particulate matter of San Francisco Bay: Environmental Science and Technology, v. 34, no. 4, p. 552-559.

Karickhoff, S.W., Brown, D.S., and Scott, T.A., 1979, Sorption of hydrophobic pollutants on natural sediments: Water Research, v. 13, p. 241-248.

Larson, M.C., Gellis, A.C., Glysson, G.D., Gray, J.R., and Horowitz, A.J., 2010, Fluvial sediment in the environment-A national challenge, in Hydrology and Sedimentation for a Changing Future-Existing and Emerging Issues, Second Joint Federal Interagency Conference on Sedimentation and Hydrologic Modeling, Las Vegas, Nevada, June 27-July 1, 2010, proceedings: $15 \mathrm{p}$.

Li, An, Jang, Jae-Kil, and Scheff, P.A., 2003, Application of EPA CMB8.2 model for source apportionment of sediment PAHs in Lake Calumet, Chicago: Environmental Science and Technology, v. 37, no. 13, p. 2,958-2,965.

Lindsey, B.D., Breen, K.J., Bilger, M.D., and Brightbill, R.A., 1998, Water quality in the Lower Susquehanna River Basin, Pennsylvania and Maryland, 1992-95: U.S. Geological Survey Circular 1168, 38 p., available at http://pubs.usgs. gov/circ/circ1168/.

Llewellyn, T.O., 1994, Cadmium (materials flow): Bureau of Mines Information Circular 9380, 17 p.

MacDonald, D.D., Dipinto, L.M., Field, J., Ingersoll, C.G., Long, E.R., and Swartz, R.C., 2000, Development and evaluation of consensus-based sediment effect concentrations for polychlorinated biphenyls: Environmental Toxicology and Chemistry, v. 19, p. 1,403-1,413.
MacDonald, D.D., Ingersoll, C.G., and Berger, T.A., 2000, Development and evaluation of consensus-based sediment quality guidelines for freshwater ecosystems: Archives of Environmental Contamination and Toxicology, v. 39, p. $20-31$.

Mahler, B.J., and Van Metre, P.C., 2003, A simplified approach for monitoring of hydrophobic organic contaminants associated with suspended sediment-Methodology and applications: Archives of Environmental Contamination and Toxicology, v. 44, p. 288-297.

Mahler, B.J., Van Metre, P.C., Bashara, T.J., Wilson, J.T., and Johns, D.A., 2005, Parking lot sealcoat-An unrecognized source of urban PAHs: Environmental Science and Technology, v. 39. p. 5,560-5,566.

Mahler, B.J., Van Metre, P.C., Wilson, J.T., Guilfoyle, A.L., and Sunvison, M.W., 2006, Concentrations, loads, and yields of particle-associated contaminants in urban creeks, Austin, Texas, 1999-2004: U.S. Geological Survey Scientific Investigations Report 2006-5262, 107 p.

Metcalf, R.L., 1995, Insect control technology_-Volume 14, in Kroschwitz, J., and Howe-Grant, M., eds., Kirk-Othmer encyclopedia of chemical technology (4th ed.): New York, John Wiley, p. 524-602.

National Institute of Standards and Technology, 2003, Certificate of analysis, standard reference material 2709, San Joaquin soil-Baseline trace element concentrations: accessed February 3, 2011, at https://www-s.nist.gov/ srmors/certificates/2709.pdf.

National Institute of Standards and Technology, 2008, Report of investigation, reference material 8704, Buffalo River sediment: accessed February 3, 2011, at https://www-s.nist. gov/srmors/reports/8704.pdf.

National Oceanic and Atmospheric Administration, 2010, Local climatological data publications (monthly summaries for 1996 forward): U.S. Department of Commerce, National Environmental Satellite, Data, and Information Service, National Climatic Data Center, accessed February 13, 2010 , at http://www7.ncdc.noaa.gov/IPS/lcd/lcd.html.

Noriega, M.C., Wydoski, D.S., and Foreman, W.T., 2003, Methods of analysis by the U.S. Geological Survey National Water Quality Laboratory-Determination of organochlorine pesticides and polychlorinated biphenyls in bottom and suspended sediment by gas chromatography with electron capture detection: U.S. Geological Survey Water-Resources Investigations Report 03-4293, 46 p.

Norstrom, R.J., Simon, M., Moisey, J., Wakeford, B., and Weseloh, D.V.C., 2002, Geographical distribution (2000) and temporal trends (1981-2000) of brominated diphenyl ethers in Great Lakes herring gull eggs: Environmental Science and Technology, v. 36, p. 4,783-4,789. 
Ockerman, D.J., and McNamara, K.C., 2003, Simulation of streamflow and estimation of streamflow constituent loads in the San Antonio River watershed, Bexar County, Texas, 1997-2001: U.S. Geological Survey Water-Resources Investigations Report 03-4030, 37 p.

Olson, M.C., Iverson, J.L., Furlong, E.T., and Schroeder, M.P., 2004, Methods of analysis by the U.S. Geological Survey National Water Quality Laboratory-Determination of polycyclic aromatic hydrocarbon compounds in sediment by gas chromatography/mass spectrometry: U.S. Geological Survey Water-Resources Investigations Report 03-4318, $45 \mathrm{p}$.

Pacyna, E.G., Pacyna, J.M., Steenhuisen, F., and Wilson, S., 2006, Global anthropogenic mercury emission inventory for 2000: Atmospheric Environment, v. 40, p. 4,048-4,063.

Pearson, R.F., Hornbuckle, K.C., Eisenreich, S.J., and Swackhamer, D.L., 1996, PCBs in Lake Michigan water revisited: Environmental Science and Technology, v. 30, p. 1,429-1,436.

Pirkey, K.D., and Glodt, S.R., 1998, Quality control at the U.S. Geological Survey National Water Quality Laboratory: U.S. Geological Survey Fact Sheet FS-026-98, 4 p.

Potts, P.J., Tindle, A.G., and Webb, P.C., 1992, Geochemical reference material compositions-Rocks, minerals, sediments, soils, carbonates, refractories, and ores used in research and industry: Boca Raton, Fla., CRC Press, 313 p.

Rice, K.C., 1999, Trace element concentrations in streambed sediment across the conterminous United States: Environmental Science and Technology, v. 33, p. 2,499-2,504.

Ryker, S.J., 2001, Mapping arsenic in groundwater: Geotimes, v. 46 , p. $34-36$.

San Antonio Water System, 2009, Water quality reportWhere our water comes from: accessed March 9, 2010, at http://www.saws.org/Our_Water/waterquality/Report/where. shtml.

Shelton, L.R., and Capel, P.D., 1994, Guidelines for collecting and processing samples of stream bed sediment for analysis of trace elements and organic contaminants for the National Water-Quality Assessment Program: U.S. Geological Survey Open-File Report 94-458, 20 p.

Silliman, J.E., Meyers, P.A., and Eadie, B.J., 1998, PeryleneAn indicator of alteration processes or precursor materials?: Organic Geochemistry, v. 29, p. 1,737-1,744.

Sjödin, Andreas, Päpke, Olaf, McGahee, Ernest, Focant, Jean-Francois, Jones, R.S., Pless-Mulloli, Tanja, Leontjew Toms, Leisa-Maree, Herrmann, Thomas, Müller, Jochen, Needham, L.L., and Patterson, D.G., Jr., 2008, Concentration of polybrominated diphenyl ethers (PBDEs) in household dust from various countries: Chemosphere, v. 73, p. S131-S136.

Sjödin, Andreas, Patterson, D.G., Jr., and Bergman, Åke, 2001, Brominated flame retardants in serum from US blood donors: Environmental Science and Technology, v. 35, no. 19 , p. $3,830-3,833$.

Smith, J.A., Witkowski, P.J., and Fusillo, T.V., 1988, Manmade organic compounds in the surface water of the United States-A review of current understanding: U.S. Geological Survey Circular 1007, 92 p.

Spencer, W.F., and Cliath, M.M., 1972, Volatility of DDT and related compounds: Journal of Agricultural and Food Chemistry, v. 20, no. 3, p. 645-649.

StatSoft, Inc., 2009, STATISTICA (data analysis software system), version 9.0: available at http://www.statsoft.com.

Stumm, W., and Morgan, J.J., 1981, Aquatic chemistry-An introduction emphasizing chemical equilibria in natural waters ( 2 d ed.): New York, John Wiley, 780 p.

Taggart, J.E., Jr., ed., 2002, Analytical methods for chemical analysis of geologic and other materials: U.S. Geological Survey Open-File Report 02-223 [variously paged].

Texas Commission on Environmental Quality, 2009a, Source Water Assessment and Protection Program: accessed April 23, 2008, at http://www.tceq.state.tx.us/permitting/ water_supply/pdw/SWAP.

Texas Commission on Environmental Quality, 2009b, Wind roses: accessed April 13, 2010, at http://www.tceq.state. tx.us/compliance/monitoring/air/monops/windroses.html.

Texas Commission on Environmental Quality, 2010a, Draft 2010 guidance for assessing and reporting surface water quality in Texas (June 6, 2009) - In compliance with sections 305(b) and 303(d) of the Federal Clean Water Act: Surface Water Quality Monitoring Program, Monitoring and Assessment Section, Water Quality Planning Division, accessed March 2, 2010, at http://www.tceq.state.tx.us/ assets/public/compliance/monops/water/10twqi/2010_ guidance.pdf.

Texas Commission on Environmental Quality, 2010b, Draft 2010 Texas integrated report for Clean Water Act sections 305(b) and 303(d): Surface Water Quality Monitoring Program, Monitoring and Assessment Section, Water Quality Planning Division, accessed March 11, 2011, at http://www.tceq.texas.gov/compliance/monitoring/water/ quality/data/10twqi/10twqi.

Texas Department of Health, 2003, Quantitative risk characterization, lower Leon Creek, San Antonio, Bexar County, Texas: Austin, Seafood Safety Division, Environmental Epidemiology and Toxicology Division, $21 \mathrm{p}$. 
Texas Department of State Health Services, 2008, Water bodies tested by the Texas Department of State Health Services where no consumption advisories or possession bans were issued: accessed January 28, 2010, at http://www.dshs.state. tx.us/seafood/PDF2/NoAdvisory.pdf.

Texas Department of State Health Services, 2010, Characterization of potential adverse health effects associated with consuming fish from lower Leon Creek, Bexar County, Texas: Austin, Division for Regulatory Services; Policy, Standards, and Quality Assurance Unit; Seafood and Aquatic Life Group, 46 p.

TIBCO Software Inc., 2008, TIBCO Spotfire S+ Version 8.1.1 for Microsoft Windows: available at $h t t p: / / s p o t f i r e . t i b c o$. com/products/s-plus/statistical-analysis-software.aspx.

U.S. Air Force, 2007, Community relations plan for the former Kelly Air Force Base: Air Force Real Property Agency, accessed March 18, 2008, at http://www.safie.hq.af.mil/ shared/media/document/AFD-070924-112.pdf.

U.S. Army Environmental Command, 2009, Camp Bullis and Fort Sam Houston candidate evaluation report: accessed January 28, 2010, at http://aec.army.mil/usaec/cleanup/ pba-cer-bullis.pdf.

U.S. Census Bureau, 2001, Census 2000 summary file 1 (SF 1) 100-percent data-Texas, Bexar County: accessed April 8, 2010, at http://factfinder.census.gov/servlet/ DownloadDatasetServlet?_lang=en .

U.S. Census Bureau, 2009, Table 1-Annual estimates of the resident population for incorporated places over 100,000, ranked by July 1, 2008 population (April 1, 2000 to July 1, 2008): U.S. Census Bureau, Population Division, p. 1.

U.S. Environmental Protection Agency, 1993, Provisional guidance for quantitative risk assessment of polycyclic aromatic hydrocarbons: Cincinnati, Ohio, Office of Health and Environmental Assessment, Environmental Criteria and Assessment Office.

U.S. Environmental Protection Agency, 1996, Method 3050B - Acid digestion of sediments, sludges, and soils: accessed July 20, 2010, at http://www.epa.gov/wastes/ hazard/testmethods/sw846/pdfs/3050b.pdf.

U.S. Environmental Protection Agency, 1997, The incidence and severity of sediment contamination in surface waters of the United States, Volume 1-National sediment quality survey: Office of Science and Technology, EPA-823-R-97-006, 302 p.

U.S. Environmental Protection Agency, 2006, Certain polybrominated diphenylethers-Significant new use rule: Federal Register, v. 71, no. 113, p. 34,015-34,021.

U.S. Environmental Protection Agency, 2008, Chemical mass balance (CMB) model EPA-CMBv8.2: accessed February
18, 2010, at http://www.epa.gov/scram001/receptor_cmb. htm.

U.S. Environmental Protection Agency, 2010a, Envirofacts, Facility Registry System, facility detail reportRandolph Air Force Base: accessed December 9, 2010, at http://oaspub.epa.gov/enviro/fii_query_dtl. disp_program_facility?p_registry_id=110002134495.

U.S. Environmental Protection Agency, 2010b, Envirofacts, Facility Registry System, facility detail report-U.S. Air Force Lackland AFB TX Arms Training Range: accessed December 9, 2010, at http://oaspub.epa.gov/ enviro/fii_query_dtl.disp_program_facility?pgm_sys_id_ in $=T X 4571524129 \& p g m \_s y s \_a c r n m \_i n=C E R C L I S$.

U.S. Environmental Protection Agency, 2010c, Polybrominated diphenylethers (PBDEs): Office of Pollution Prevention and Toxics, accessed February 22, 2010, at http://www.epa.gov/oppt/pbde/.

U.S. Environmental Protection Agency, 2010d, Superfund site information: Superfund Information Systems, accessed January 14, 2011, at http://www.epa.gov/superfund/sites/ siteinfo.htm.

U.S. Environmental Protection Agency, 2010e, Toxics release inventory (TRI) - Facility locator tool: accessed January 14, 2011, at http://www.epa.gov/tri-efdr/.

U.S. Environmental Protection Agency, 2011, Envirofacts, Facility Registry System, facility detail report—Brooks City Base: accessed May 12, 2011, at http://oaspub.epa.gov/ enviro/fii_query_dtl.disp_program_facility?pgm_sys_id_ in $=$ TX2572024303\&pgm_sys_acrnm_in $=$ CERCLIS.

U.S. Geological Survey, 2011, National Water Information System-USGS water data for Texas: accessed March 2011 at $h t t p: / /$ waterdata.usgs.gov/tx/nwis/.

U.S. Geological Survey, 2004, Revised policy for the approval of U.S. Geological Survey (USGS) water-quality analytical methods: Office of Water Quality Technical Memorandum 04.01, accessed June 23, 2011, at http://water.usgs.gov/ admin/memo/QW/qw04.01.html.

Van Metre, P.C., Callender, Edward, and Fuller, C.C., 1997, Historical trends in organochlorine compounds in river basins identified using sediment cores from reservoirs: Environmental Science and Technology, v. 31, p. 2,339-2,334.

Van Metre, P.C., and Mahler, B.J., 2010, Contribution of PAHs from coal-tar pavement sealcoat and other sources to 40 U.S. lakes: Science of the Total Environment v. 409, p. 334-344.

Van Metre, P.C., Mahler, B.J., and Wilson, J.T., 2009, PAHs underfoot-Contaminated dust from sealcoated pavements: Environmental Science and Technology, v. 43, p. 20-25. 
Van Metre, P.C., Wilson, J.T., Fuller, C.C., Callender, Edward, and Mahler, B.J., 2004, Collection, analysis, and agedating of sediment cores from 56 U.S. lakes and reservoirs sampled by the U.S. Geological Survey, 1992-2001: U.S. Geological Survey Scientific Investigations Report 20045184, 180 p.

Van Metre, P.C., Wilson, J.T., Harwell, G.R., Gary, M.O., Heitmuller, F.T., and Mahler, B.J., 2003, Occurrence, trends, and sources in particle-associated contaminants in selected streams and lakes in Fort Worth, Texas: U.S. Geological Survey Water-Resources Investigations Report 03-4169, $154 \mathrm{p}$.

Williamson, A.K., Munn, M.D., Ryker, S.J., Wagner, R.J., Ebbert, J.C., and Vanderpool, A.M., 1998, Water quality in the central Columbia Plateau, Washington and Idaho, 1992-95: U.S. Geological Survey Circular 1144, 35 p.
Wong, C.S., Capel, P.D., and Nowell, L.H., 2000, Organochlorine pesticides and PCBs in stream sediment and aquatic biota-Initial results from National WaterQuality Assessment Program, 1992-1995: U.S. Geological Survey Water-Resources Investigations Report 00-4053, $88 \mathrm{p}$.

Zaugg, S.D., Burkhardt, M.R., Burbank, T.L., Olsen, M.C., Iverson, J.L., and Schroeder, M.P., 2006, Determination of semivolatile organic compounds and polycyclic aromatic hydrocarbons in solids by gas chromatography/mass spectrometry: U.S. Geological Survey Techniques and Methods, book 5, chap. B3, 44 p.

Zegers, B.N., Lewis, W.E., and Boon, J.P., 2000, Levels of some polybrominated diphenyl ether (PBDE) flame retardants in dated sediment cores: Organohalogen Compounds, v. 47, p. 229-232.
Publishing support provided by Lafayette Publishing Service Center

Information regarding water resources in Texas is available at 


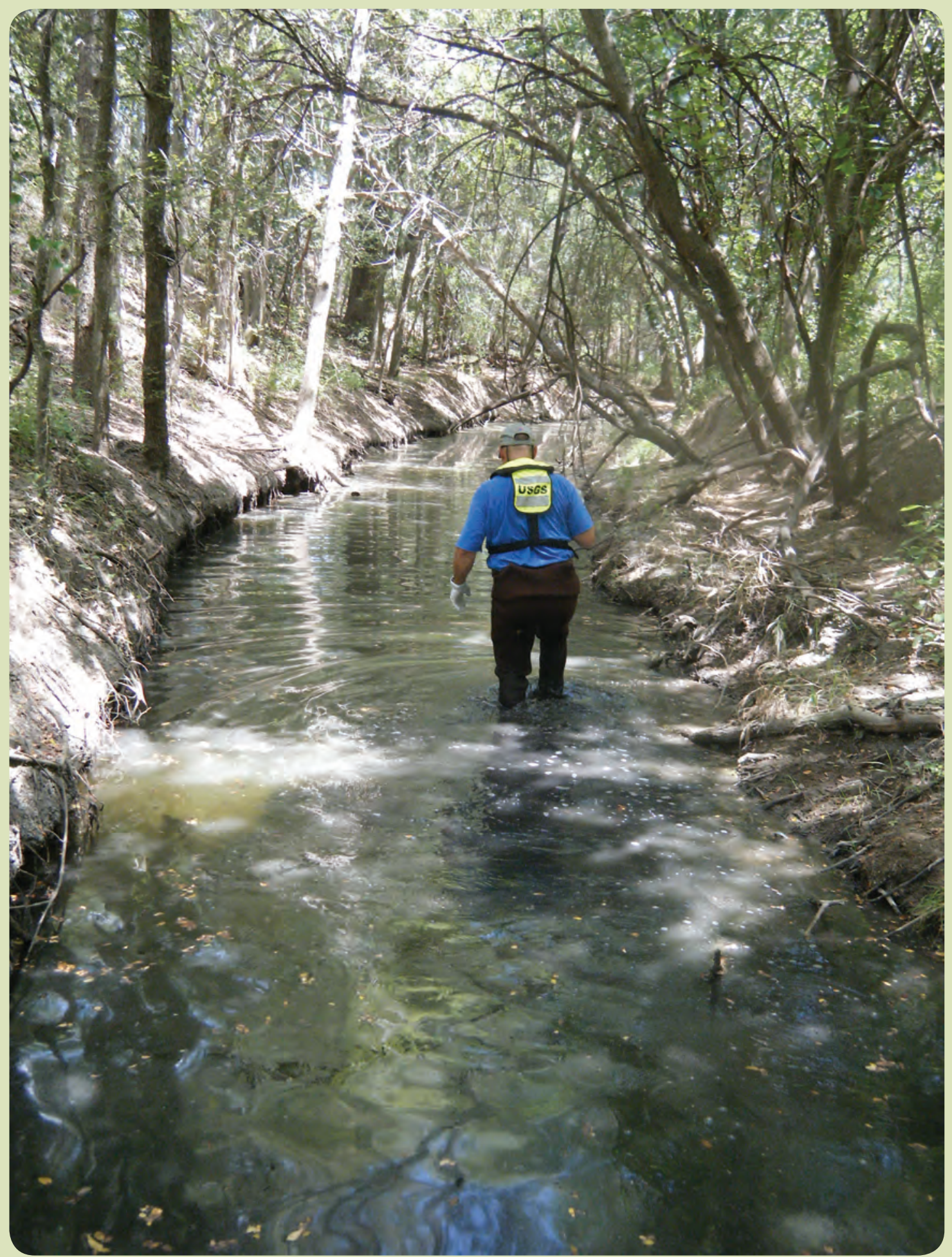

I SBN 978- 1- 4113-3185-

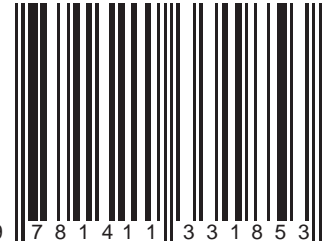

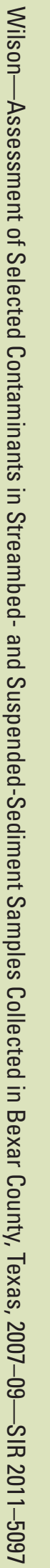

